JOSÉ EDUARDO RODRIGUES VARANDAS JÚNIOR

\title{
INTERPRETAÇÃO DA INFLUÊNCIA DAS VARIÁVEIS CONDICIONANTES DA DEMANDA PELA PRODUÇÃO HABITACIONAL PRIVADA: APLICAÇÃO NA CIDADE DE SÃO PAULO DURANTE O PERÍODO DE 1998 A 2008
}

Dissertação apresentada à Escola Politécnica da Universidade de São Paulo para obtenção do título de Mestre em Engenharia

Orientador: Prof. Dr. Claudio Tavares de Alencar

SÃO PAULO 
JOSÉ EDUARDO RODRIGUES VARANDAS JÚNIOR

\section{INTERPRETAÇÃO DA INFLUÊNCIA DAS VARIÁVEIS CONDICIONANTES DA DEMANDA PELA PRODUÇÃO HABITACIONAL PRIVADA: APLICAÇÃO NA CIDADE DE SÃo PAULO DURANTE O PERÍODO DE 1998 A 2008}

Dissertação apresentada à Escola Politécnica da Universidade de São Paulo para obtenção do título de Mestre em Engenharia

Orientador: Prof. Dr. Claudio Tavares de Alencar

Área de Concentração: Engenharia Civil

SÃO PAULO 
Este exemplar foi revisado e alterado em relação à versão original, sob responsabilidade única do autor e com a anuência de seu orientador.

São Paulo, 07 de Maio de 2009

Assinatura do autor

Assinatura do orientador

FICHA CATALOGRÁFICA

Varandas Júnior, José Eduardo Rodrigues

Interpretação da influência das variáveis condicionantes da demanda pela produção habitacional privada: aplicação na cidade de São Paulo durante o período de 1998 a 2008 / J.E.R. Varandas Júnior. -- São Paulo, 2010.

p.

Dissertação (Mestrado) - Escola Politécnica da Universidade de São Paulo. Departamento de Engenharia de Construção Civil.

1. Habitação - São Paulo (SP) 2. Demanda I. Universidade de São Paulo. Escola Politécnica. Departamento de Engenharia de Construção Civil II. t. 
À minha namorada, Carolina, pelo apoio, paciência e compreensão ao longo da realização deste trabalho.

Aos meus pais, Dalva e José Eduardo (in memoriam), e avós, Tereza (in memoriam) e Antonio, grandes incentivadores e responsáveis pelas conquistas em todas as etapas da minha vida. 


\section{AGRADECIMENTOS}

Ao Professor Dr. Claudio Tavares de Alencar pela sua orientação e estímulo para o desenvolvimento desta dissertação, aos Professores Dr. João da Rocha Lima Jr., Professora Dra. Eliane Monetti e Dr. Sérgio Alfredo Rosa pelos conhecimentos transmitidos.

Aos amigos Alessandro Vedrossi e Luciano Guagliardi pelo incentivo e suporte na realização do mestrado. Aos meus amigos que sempre apoiaram, incentivaram e compreenderam a importância deste projeto.

A todos os colegas do curso de pós-graduação, e aqueles que, de alguma forma, me ajudaram na realização deste trabalho. 
Eu escuto e esqueço. Vejo e lembro. Faço e entendo.

(Confúcio) 


\section{RESUMO}

Para analisar a evolução da produção habitacional privada é necessário compará-la ao comportamento da demanda, que, neste caso, tem a formação de domicílios como uma de suas principais componentes. Analisando o mercado habitacional brasileiro, tem-se uma clara tendência de incremento no número de unidades produzidas após o final da década de 70 , resultado do crescimento populacional e da forte atuação do Banco Nacional da Habitação $(\mathrm{BNH})$, principal fomentador deste setor naquele período por meio do Sistema Financeiro de Habitação (SFH).

No entanto, nas duas décadas subseqüentes, mesmo com a continuidade do incremento de domicílios no país, a produção de unidades experimentou um período de retração. Esta nova condição provocou um descolamento entre a produção habitacional privada e a sua principal componente de demanda: a formação de domicílios. Após a deterioração do ambiente econômico e a extinção do $\mathrm{BNH}$, o mercado de empreendimentos imobiliários habitacionais sofreu com a falta de direcionamento de recursos para o setor. Esta condição somente se alterou a partir de 2002, com alterações na dinâmica do SFH e de uma melhora no ambiente econômico de forma geral, que, em conjunto, contribuíram para o regresso de recursos ao mercado habitacional e impactaram positivamente a produção de novas unidades. Em 2006 foram realizadas as primeiras aberturas de capital dos empreendedores do setor, o que trouxe ainda mais recursos para o mercado e elevou o nível da produção habitacional privada a outro patamar.

Este trabalho realiza uma revisão bibliográfica sobre o tema demanda habitacional e suas interfaces com o ambiente econômico. A partir da análise da produção habitacional privada na cidade de São Paulo de 1998 até 2008 frente às variáveis condicionantes selecionadas: formação de domicílios, renda, oferta de recursos, custos do financiamento habitacional, preço e taxa de atratividade são interpretadas as fontes de distorção que provocaram o descolamento entre a formação de domicílios e a produção habitacional privada no período. 


\begin{abstract}
When analyzing the residential real estate market one of the main factors that influence its behavior is the demand, which has a strong relation with the household formation. According to the Brazilian housing market history, it is possible to notice an upward trend after the end of the 70's, which was positively influenced by the population growth and the strong performance of the Banco Nacional da Habitação $(\mathrm{BNH})$ - the main financial institution player responsible to support the sector in that period.
\end{abstract}

However, in the next two decades, even considering the Brazilian household increase, the residential real estate market faced a decrease in the new offer of units causing a gap between the housing construction and its main demand component: the household formation. After the economic turmoil and the extinction of the $\mathrm{BNH}$, the residential real estate market had no access to sources of funds to support the business. This scenario started to change in 2002, after an improvement in the Brazilian economic conditions and in the SFH, which ended up with an increase in the availability of funds to the sector, a better business environment and a growth in the housing construction. In 2006 the first developers went public bringing more funds to the sector and leading the housing construction to a new level.

This paper analysis the academic work's state of art regarding the housing demand and its interfaces with the economic environment. The causes of the gap between the housing construction and the household formation are identified according to the behavior of the variables selected: household formation, income, availability of funds, financing costs, price and capitalization rate. 


\section{SUMÁRIO}

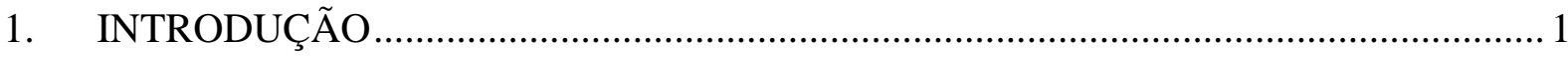

1.1.CONTEXTUALIZAÇÃO DO TRABALHO....................................................... 1

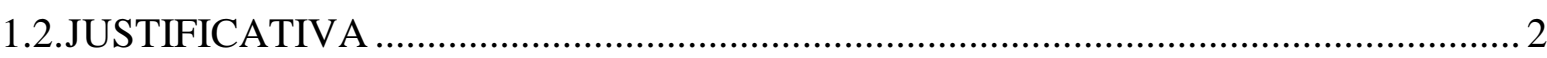

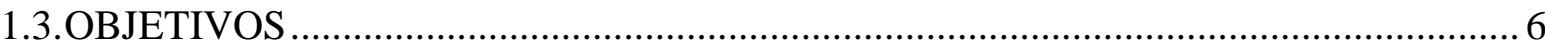

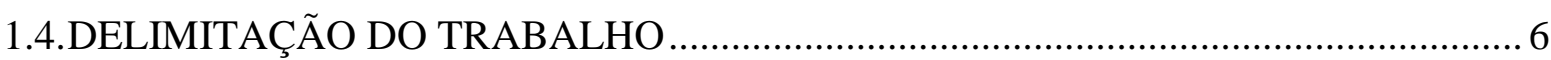

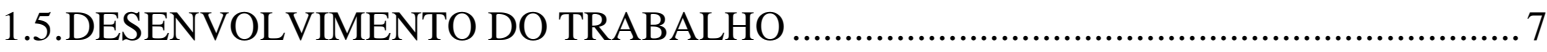

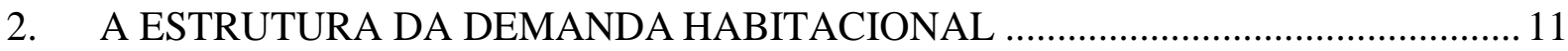

2.1.Abordagem tradicional do estudo da demanda habitacional ........................................ 11

2.2.Equilíbrio do mercado de empreendimentos imobiliários no longo prazo...................... 16

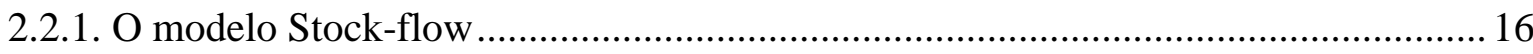

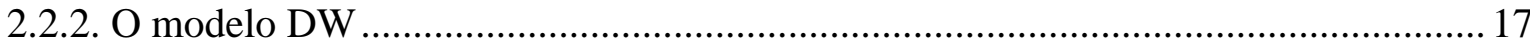

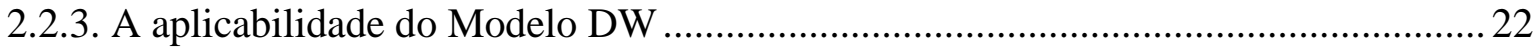

2.3. Variáveis condicionantes da produção habitacional...................................................... 24

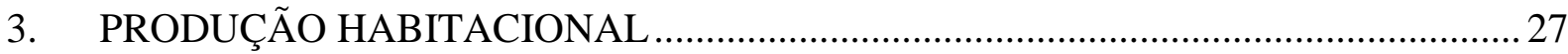

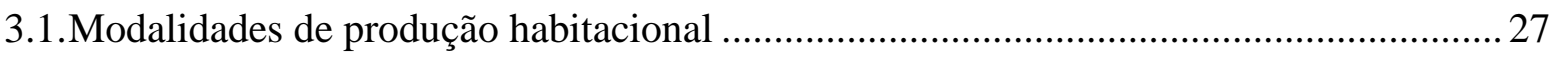

3.2.O ambiente de negócio do mercado da Produção Habitacional Privada ......................... 28

3.3.Identificação da produção de unidades na cidade de São Paulo no período

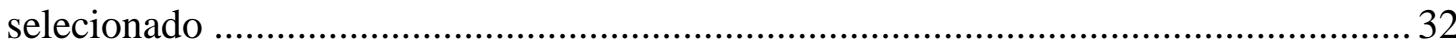

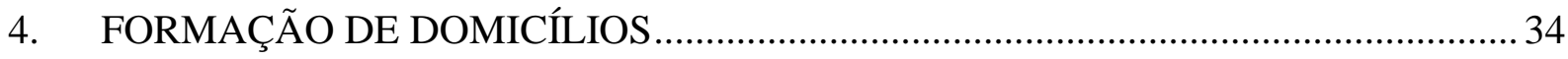

4.1.Metodologias de projeção da Formação de Domicílios ................................................... 34

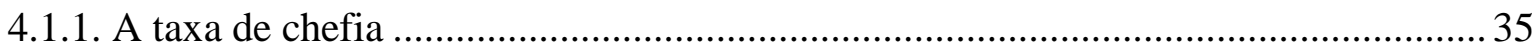

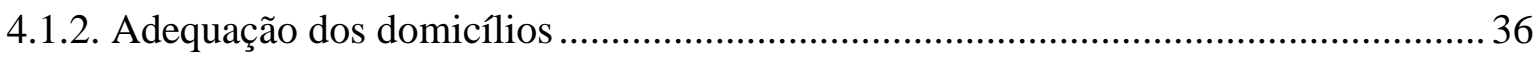

4.2. Comportamento da formação de domicílios na cidade de São Paulo no período

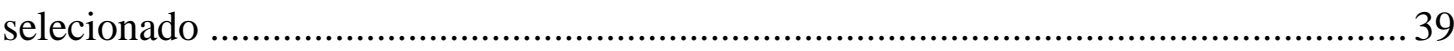

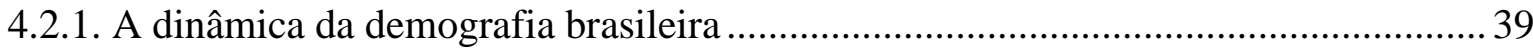

4.2.2. A formação de domicílios adequados no período selecionado.................................... 44

4.2.3. A formação de domicílios comparada à produção de unidades................................... 45

5. A OFERTA DE RECURSOS PARA O SETOR HABITACIONAL ............................. 48

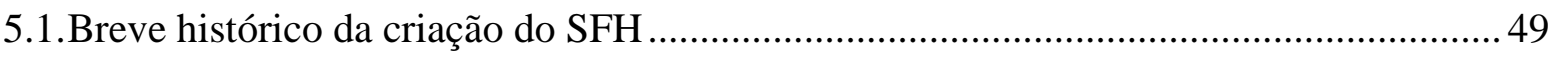

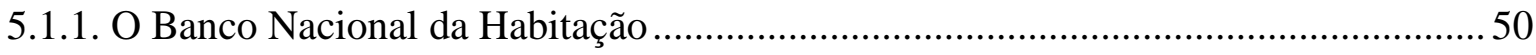

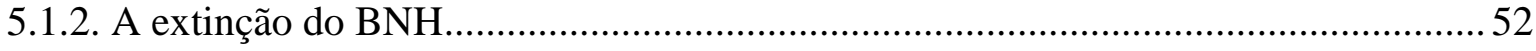

5.2.Participação do SFH no financiamento do setor habitacional no período selecionado... 53 
5.2.1. A participação do crédito imobiliário no sistema financeiro brasileiro 54

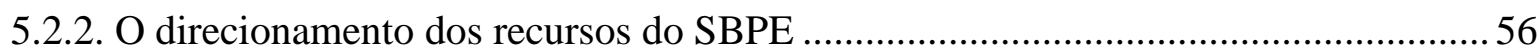

5.2.3. A oferta de recursos no SBPE e a produção de unidades no período ......................... 59

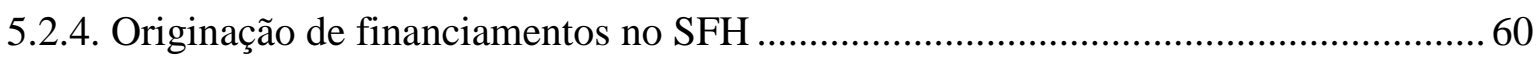

5.2.5. Originação de financiamento para a produção de unidades novas no SFH............... 63

5.2.6. Originação de financiamento para aquisição de unidades novas no SFH ................. 64

5.2.7. Produção Habitacional Privada na cidade de São Paulo com financiamento à

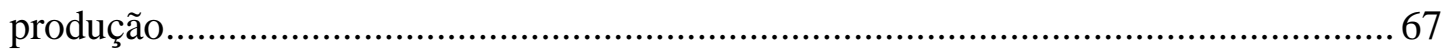

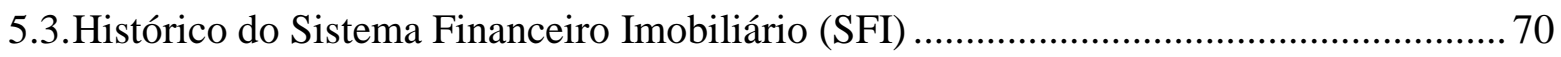

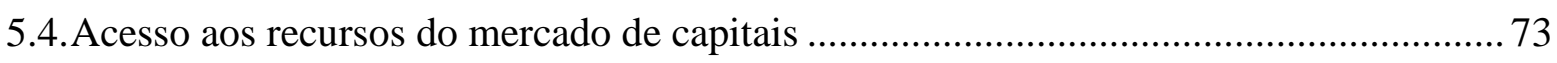

5.5.Comportamento da produção de unidades frente à oferta de recursos ........................... 76

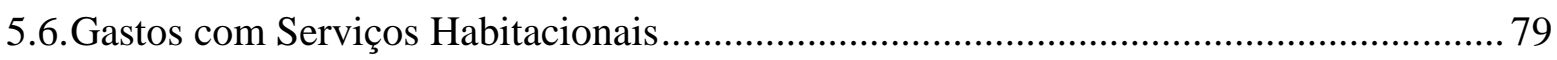

6. COMPORTAMENTO DAS DEMAIS VARIÁVEIS SELECIONADAS ..................... 81

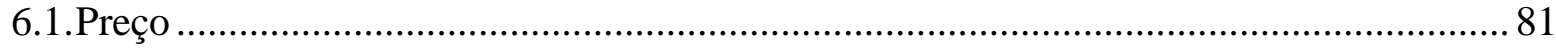

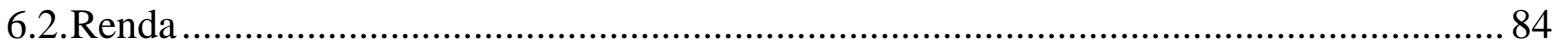

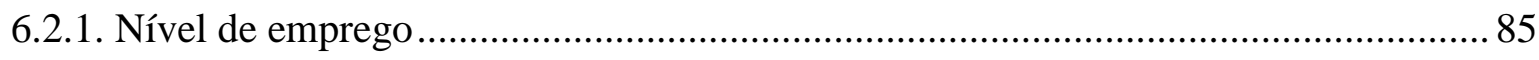

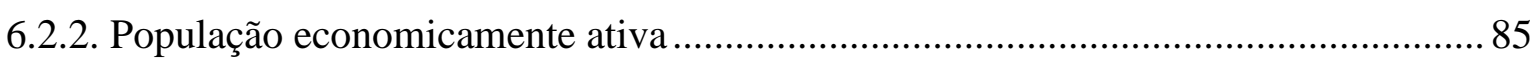

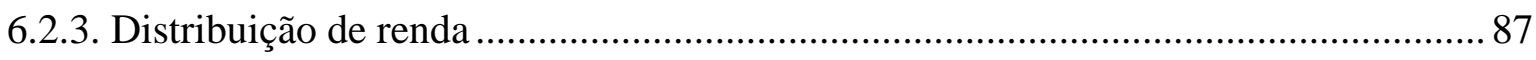

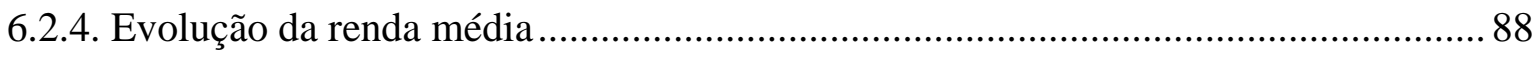

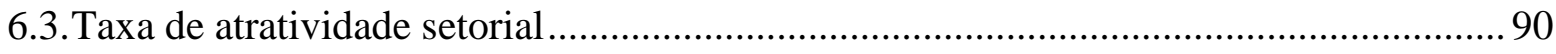

6.4.Comportamento de outros indicadores no período selecionado .....................................94

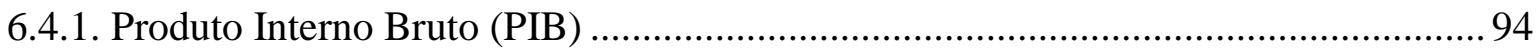

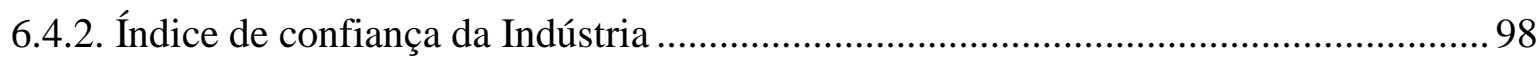

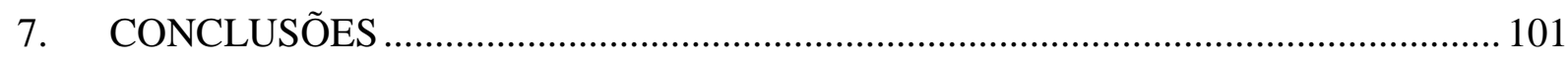

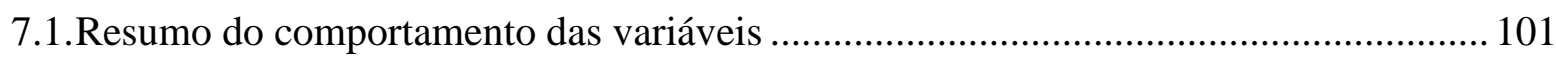

7.2.O impacto da Oferta de Recursos no período selecionado .......................................... 102

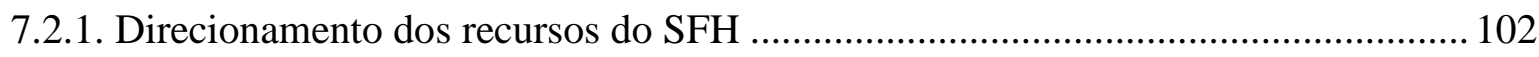

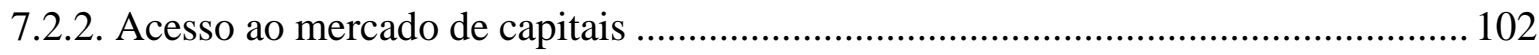

7.2.3. A necessidade de novos recursos para o desenvolvimento do setor ........................ 103

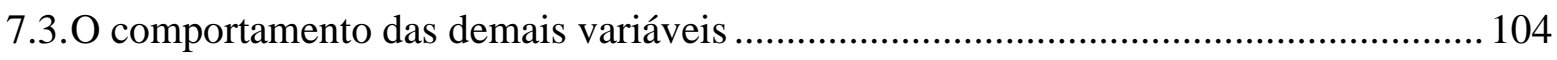

7.4.Potencial não atendido pelo mercado de produção privada no período ......................... 106

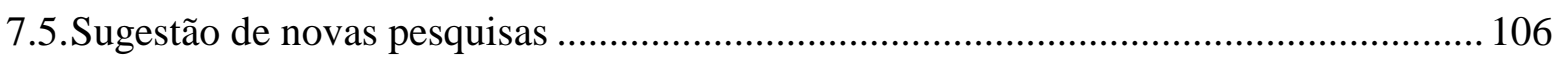

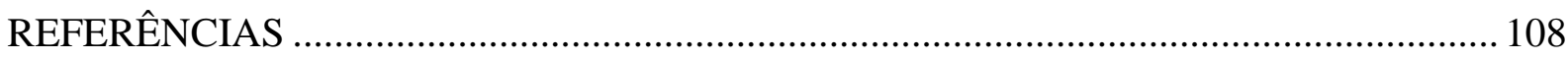




\section{LISTA DE FIGURAS}

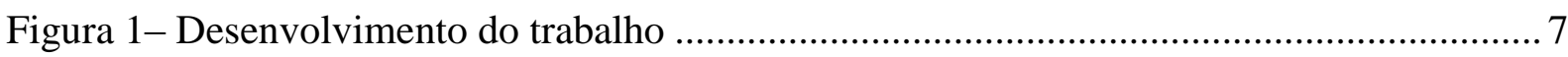

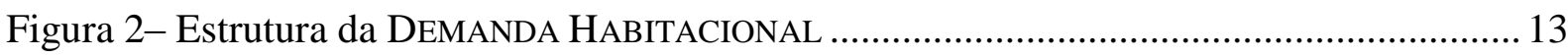

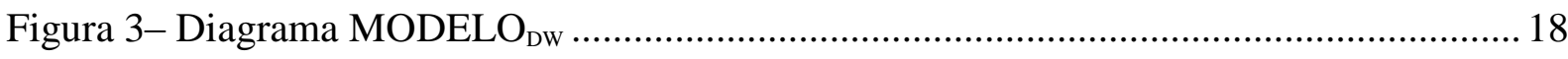

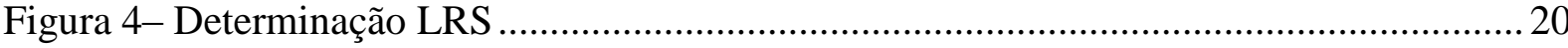

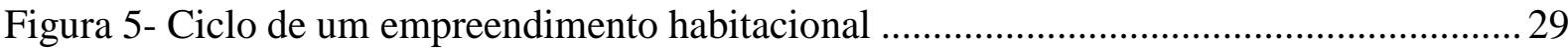

Figura 6 - Pirâmide etária da população brasileira em 1980 …............................................... 40

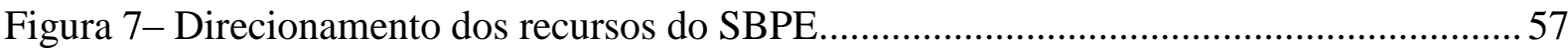




\section{LISTA DE EQUAÇÕES}

EQ(1) Equação geral da Demanda Habitacional ................................................................ 12

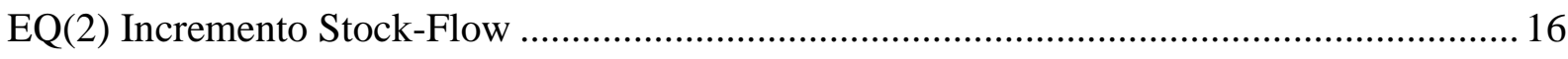

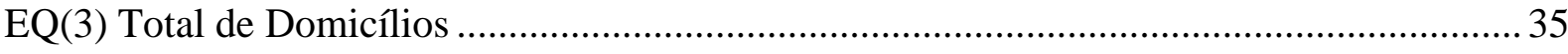

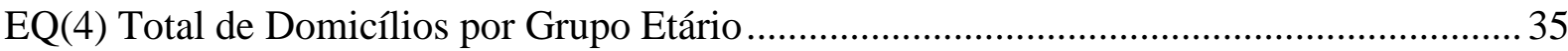

EQ(5) Taxa de Chefia

EQ(6) Domicílios segundo inadequações $\quad$...................... 38 


\section{LISTA DE GRÁFICOS}

Gráfico 1 - Unidades financiadas no Brasil dentro do SFH com recursos do SBPE e do FGTS4 Gráfico 2 - Estoque de Crédito Imobiliário/ PIB 2005 .........................................................5

Gráfico 3 - Novas unidades habitacionais ofertadas na cidade de São Paulo .......................... 33

Gráfico 4 - Novas unidades habitacionais ofertadas na cidade de São Paulo (1998=100)...... 33

Gráfico 5 - Tamanho médio dos domicílios projetados segundo grandes regiões e Brasil entre

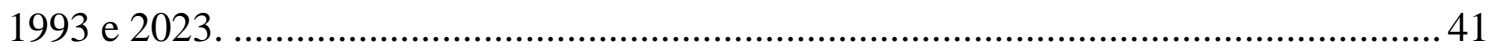

Gráfico 6 - Formação de domicílios x incremento da população do Brasil............................ 42

Gráfico 7 - Formação de domicílios x incremento da população no Sudeste do Brasil .......... 43

Gráfico 8 - Formação de domicílios adequados: Brasil x São Paulo....................................... 44

Gráfico 9 - Formação de domicílios adequados: Estado de São Paulo x RMSP e

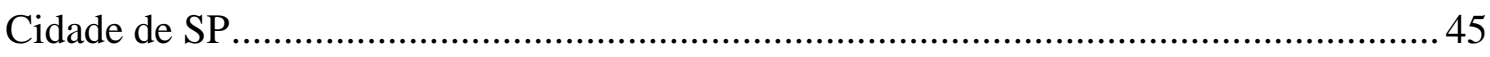

Gráfico 10 - Novas unidades habitacionais ofertadas x formação de domicílios adequados na

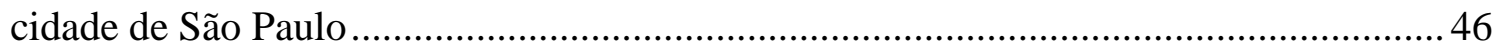

Gráfico 11 - Novas unidades habitacionais ofertadas x formação de domicílios adequados na cidade de São Paulo

Gráfico 12 - Participação do estoque total das operações de crédito do SFH e do sistema

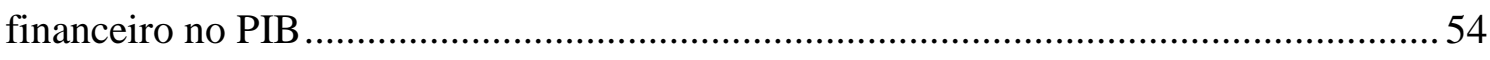

Gráfico 13 - Participação do estoque total das operações de crédito do SFH no PIB ............. 55

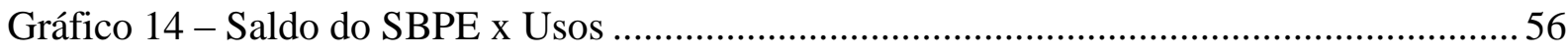

Gráfico 15 - Participação das aplicações dos recursos do SBPE..............................................57

Gráfico 16 - Saldo SBPE x Aplicações dos recursos em financiamento imobiliário................58

Gráfico 17 - Evolução dos recursos direcionados para o SFH x Limite de 65\% da exigibilidade de aplicação do saldo do SBPE x Novas unidades habitacionais

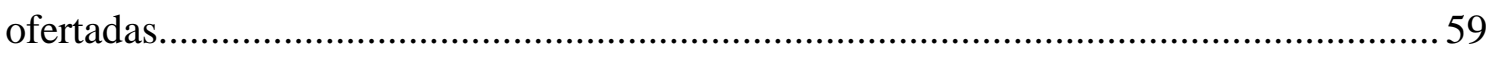

Gráfico 18 - Volume financiado originado no Brasil com recursos do SBPE ...................... 60

Gráfico 19 - Unidades financiadas originadas no Brasil com recursos do SBPE................... 61

Gráfico 20 - Volume financiado originado no Estado de São Paulo com recursos do

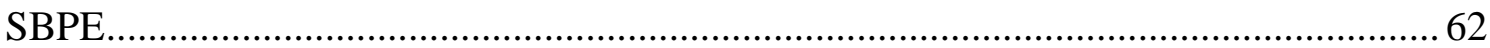

Gráfico 21 - Unidades financiadas originadas no Estado de São Paulo com recursos do SBPE

Gráfico 22 - Volume financiado originado no Brasil com recursos do SBPE para a produção de unidades novas 
Gráfico 23 - Financiamentos originados no Brasil com recursos do SBPE para a produção de unidades novas

Gráfico 24 - Volume financiado originado no Brasil com recursos do SBPE para aquisição de unidades novas

Gráfico 25 - Unidades financiadas originadas no Brasil com recursos do SBPE para aquisição de unidades novas 66

Gráfico 26 - Novas unidades habitacionais ofertadas na cidade de São Paulo segundo o público comprador

Gráfico 27 - Distribuição de novas unidades habitacionais ofertadas na cidade de São Paulo segundo o público comprador

Gráfico 28 - Distribuição das unidades lançadas na cidade de São Paulo segundo a origem dos recursos

Gráfico 29 - Emissão primária de Certificados de Recebíveis Imobiliários (CRI) 71

Gráfico 30 - Acesso aos recursos do mercado de capitais 74

Gráfico 31 - Distribuição das novas unidades habitacionais ofertadas na cidade de São Paulo segundo a estrutura de capital da empresa.

Gráfico 32 - Novas unidades habitacionais ofertadas e a originação de financiamentos por fonte de recursos 78

Gráfico 33 - Evolução da renda mínima necessária para o financiamento de uma unidade de $\mathrm{R} \$ 130$ mil em $\mathrm{R} \$$ de 2009 e a nova oferta de unidades habitacionais 80

Gráfico 34 - Comportamento da evolução do preço médio por $\mathrm{m}^{2}$ e do VMU das novas unidades habitacionais ofertadas na cidade de São Paulo 82

Gráfico 35 - Comportamento da evolução do preço por $\mathrm{m}^{2}$ das unidades lançadas na cidade de São Paulo segundo o público comprador.

Gráfico 36 - Nível do emprego formal na cidade de SP 85

Gráfico 37 - Taxa de atividade da população economicamente ativa nas Regiões Metropolitanas do Brasil 86

Gráfico 38 - Taxa de desemprego na RMSP 86

Gráfico 39 - Distribuição da renda dos domicílios em 2000. 87

Gráfico 40 - Renda média mensal por domicílio: Brasil x Sudeste x Estado de São Paulo .... 88

Gráfico 41 - Evolução da Renda média mensal por domicílio no Estado de São Paulo x Novas unidades habitacionais ofertadas na cidade de São Paulo

Gráfico 42 - Evolução da taxa SELIC (\% equivalente ao ano) 91 
Gráfico 43 - Evolução do índice de Inflação IPCA

Gráfico 44 - Evolução da taxa de juros Selic (\% equivalente ao ano) frente à Produção

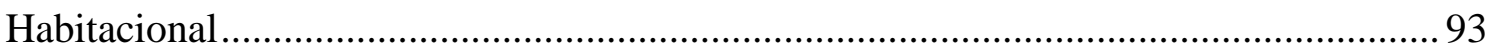

Gráfico 45 - PIB x PIB per capta x População no Brasil ...................................................... 95

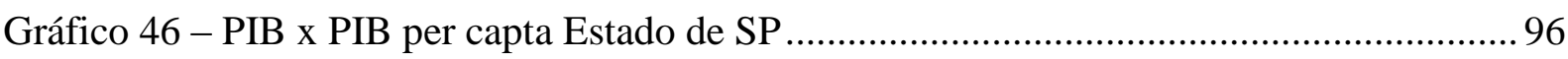

Gráfico 47 - PIB x Novas unidades habitacionais ofertadas na cidade de São Paulo ............. 97

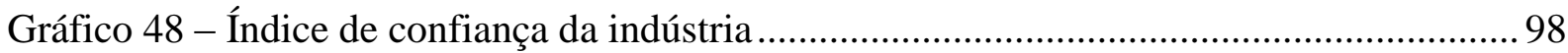

Gráfico 49 - Índice de confiança da indústria x Novas unidades habitacionais ofertadas na

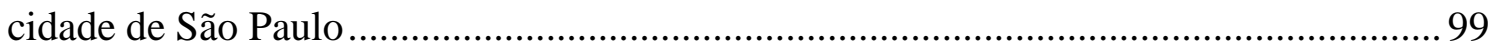




\section{LISTA DE TABELAS}

Tabela 1 - Abordagens do tema Demanda Habitacional ......................................................... 12

Tabela 2 - Modificações das condições de equilíbrio LRS ................................................. 21

Tabela 3 - Variáveis condicionantes da Produção Habitacional.............................................. 24

Tabela 4 - Premissa de comportamento das variáveis condicionantes selecionadas ............... 25 


\section{LISTA DE ABREVIATURAS}

ABECIP

BACEN

$\mathrm{BNH}$

COPOM

FIESP

FCVS

FGTS

IPCA

OPA

PES

PIB

SELIC

SFH

SFI

TAT

TR

VMU

VMF
Associação Brasileira das Entidades de Crédito Imobiliário e Poupança

Banco Central do Brasil

Banco Nacional da Habitação

Comitê da Política Monetária

Federação das Indústrias do Estado de São Paulo

Fundo de Compensação das Variações Salariais

Fundo de Garantia por Tempo de Serviço

Índice Nacional de Preços ao Consumidor Amplo

Oferta Pública de Ações

Plano de Equivalência Salarial

Produto Interno Bruto

Taxa Referencial do Sistema Especial de Liquidação e Custódia

Sistema Financeiro de Habitação

Sistema Financeiro Imobiliário

Taxa de Atratividade

Taxa Referencial

Valor Médio da Unidade

Valor Médio Financiado 


\section{INTRODUÇÃO}

A seguir serão expostas as premissas conceituais sobre as quais o trabalho será desenvolvido, apresentando a contextualização do tema proposto, justificativa da relevância do assunto e os objetivos do trabalho. Por fim será exposta a estruturação do desenvolvimento do trabalho, bem como as etapas percorridas para que os objetivos propostos fossem alcançados.

\subsection{CONTEXTUALIZAÇÃO DO TRABALHO}

A análise da produção habitacional deve considerar as características dos imóveis que se diferem de outros bens comuns na economia. A compra de um imóvel por um chefe de família exige a formação de uma poupança que, no Brasil, representa mais de uma década de economia por uma família típica. Uma alternativa a formação da poupança, considerando que o comprador tem capacidade de comprometimento de parte de sua renda mensal, é a contratação de financiamento imobiliário, que, por outro lado, é limitado pela disponibilidade de crédito no mercado. Dessa forma, é estabelecida uma importante relação entre o nível de $\operatorname{RENDA}^{1}$ da população e a disponibilidade de FINANCIAMENTO HABITACIONAL ${ }^{2}$ para os compradores no mercado da produção habitacional.

Deve-se levar em consideração que a OFERTAS DE RECURSOS ${ }^{3}$ para o setor é regulada em função das oportunidades de remuneração que os AGENTES FINANCEIROS ${ }^{4}$ possuem a disposição. Em um cenário de redução da taxa básica de juros, os

\footnotetext{
${ }^{1}$ A renda é caracterizada pelos rendimentos formais e informais que definem o poder de compra da população.

${ }^{2} \mathrm{O}$ termo FINANCIAMENTO HABITACIONAL tratado neste texto se refere ao financiamento contraído pelo comprador da unidade habitacional para fazer frente ao PREÇO

${ }^{3}$ Neste texto o termo OFERTA DE RECURSOS se refere à totalidade dos recursos disponíveis para (i) o FINANCIAMENTO HABITACIONAL, que é direcionado aos compradores das unidades habitacionais e (ii) ao FINANCIAMENTO A PRODUÇÃo que por sua vez tem a finalidade de complementar a equação de fundo dos empreendedores responsáveis pela PRODUÇÃO HABITACIONAL

${ }^{4}$ São considerados neste texto AGENTES FINANCEIROS os bancos comerciais de varejo ou atacado, os investidores institucionais nacionais ou estrangeiros e os fundos de pensão.
} 
AGENTES FINANCEIROS tendem a direcionar seus recursos para o setor produtivo da economia, aumentando a oferta de crédito em setores como o da habitação.

Analisando o público consumidor da habitação, de acordo com CARN (1988), temos que a unidade básica de consumo ${ }^{5}$ no mercado residencial é o domicilio, sendo esta a variável básica da DEMANDA HABITACIONAL ${ }^{6}$. A demanda se comportará, portanto, em função de características sociais e culturais que influenciam na FORMAÇão DE DoMicílios ${ }^{7}$, apresentando uma estreita relação com a distribuição etária da população.

A fim de apresentar uma correta interpretação do comportamento da DEMANDA HABITACIONAL, é fundamental identificar o comportamento das camadas etárias da população no que se refere à taxa de crescimento e sua composição, relacionando essas características com a FORMAÇÃO DE DOMICÍLIOS.

Esse trinômio, composto pela FORMAÇão DE DOMICílIOS, nível de RENDA e pelo acesso ao FinANCIAMENTO HABITACIONAL tende a ser o componente regulador da Produção Habitacional. Como conseqüência, o foco de pesquisa deste trabalho está centrado neste trinômio, fundamental para a interpretação dos ciclos imobiliários do mercado de EMPREENDIMENTOS IMOBILIÁRIOS HABITACIONAIS.

\subsection{JUSTIFICATIVA}

A motivação para a elaboração deste trabalho surgiu a partir da observação das transformações das condições do mercado de EMPREENDIMENTOS IMOBILIÁRIOS HABITACIONAIS brasileiro na última década que favoreceu a PRODUÇÃo HABITACIONAL PRIVADA. Uma das primeiras transformações foi iniciada em 1997

\footnotetext{
5 Apesar de o termo consumo ser associado geralmente a bens não duráveis, neste trabalho ele será utilizado para tratar a aquisição de unidades habitacionais pelos chefes de família.

${ }^{6}$ A demanda habitacional neste texto é tratada como a quantidade de chefes de domicílios capazes de locar ou adquirir uma unidade habitacional a fim de constituir um domicílio.

${ }^{7}$ Neste texto é utilizado o conceito de domicílio particular definido por IBGE (2003) como sendo o local estruturalmente separado e independente que se destina a servir de habitação a uma, duas ou, no máximo cinco famílias ou até cinco pessoas sem laços de parentesco e/ou dependência doméstica e que foi constituído com a finalidade exclusiva de servir como moradia.
} 
com a criação do Sistema Financeiro Imobiliário (SFI) que teve o objetivo de criar novos meios de acesso a recursos para financiamento tanto aos compradores quanto aos empresários do setor. Para viabilizar o acesso a novos recursos foram incorporados ao setor instrumentos que trouxeram maior segurança as operações no mercado de EMPREENDIMENTOS IMOBILIÁRIOS HABITACIONAIS. Como exemplo, podese citar a alienação fiduciária e o patrimônio de afetação.

Dentre as mudanças incorporadas no setor na última década, além da alienação fiduciária e do patrimônio de afetação já citados, pode-se destacar a maior transparência das empresas do setor que realizaram abertura de capital e adotaram um alto grau de governança corporativa a partir de 2006.

As mudanças incorporadas foram motivadas pelas dificuldades que o setor enfrentou durante o início da década de 80, principalmente após 1983 com o descontrole da inflação, implementação de diferentes planos econômicos, mudanças nas regras do Sistema Financeiro de Habitação (SFH) e finalmente na extinção do Banco Nacional da Habitação (BNH) em 1986, o qual foi responsável pelo desenvolvimento do mercado habitacional desde meados da década de 60 .

No gráfico a seguir, onde está apresentado o número em milhares de unidades financiadas ano a ano no SFH com recursos do Sistema Brasileiro de Poupança e Empréstimos (SBPE) e do Fundo de Garantia por Tempo de Serviço (FGTS), é possível notar o comportamento do mercado ao longo dos últimos 30 anos. Vale ressaltar a brusca redução do número de unidades financiadas nos primeiros anos da década de 80, como resultado das condições citadas, e no início da década de $90 \mathrm{com}$ a entrada do plano Collor em vigor. Esses eventos marcaram um período de 2 décadas de retração do mercado residencial em relação à tendência que vinha se formando até o final da década de 70. No entanto, entre 2006 e 2008, pode-se notar o crescimento no número de financiamentos concedidos em relação ao histórico das últimas décadas, o que demonstra a retomada do direcionamento de recursos para o mercado habitacional. 


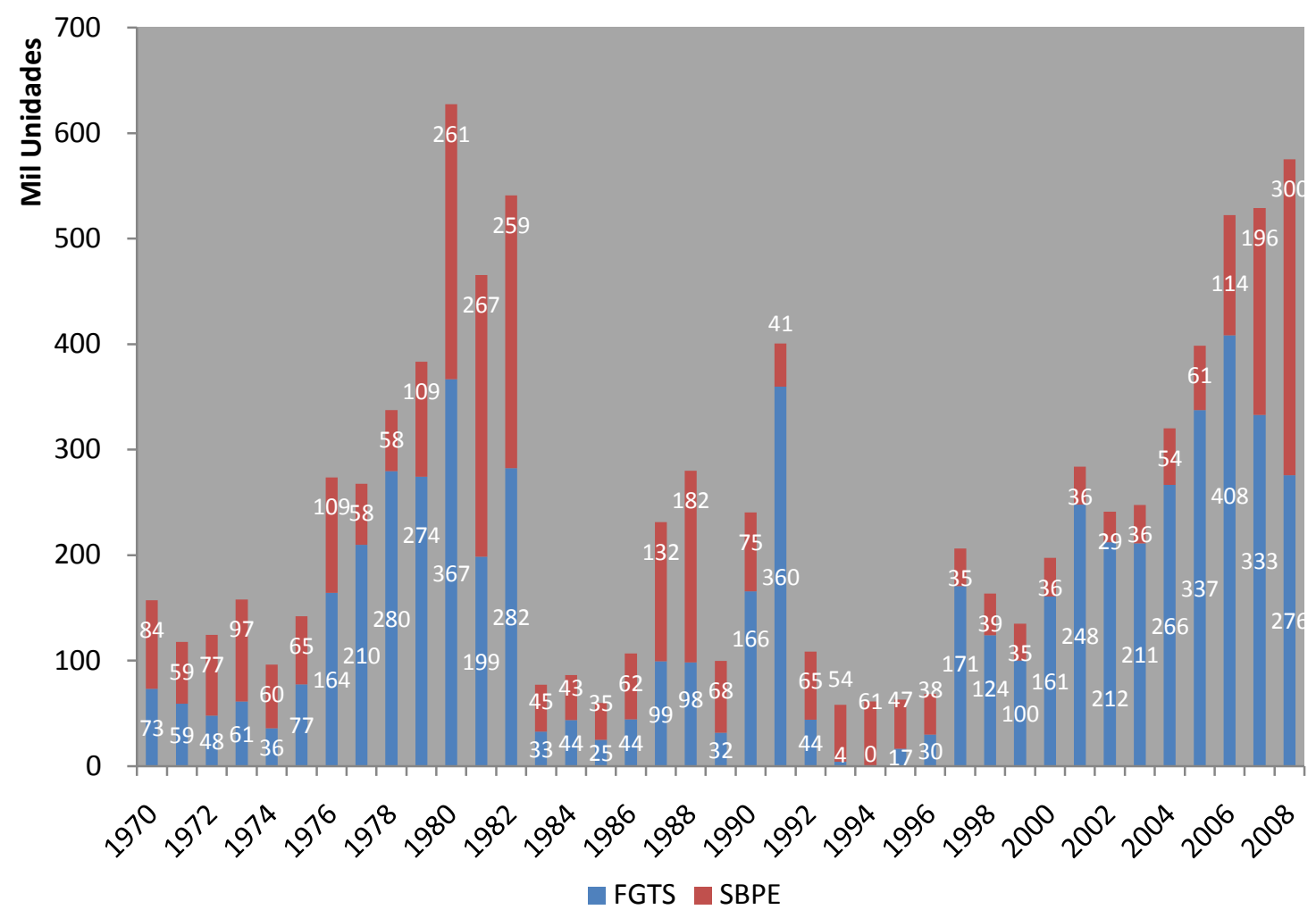

Gráfico 1 - Unidades financiadas no Brasil dentro do SFH com recursos do SBPE e do FGTS

Fonte: BACEN, ABECIP, CEF

Mesmo com o recente aquecimento do setor, a relação crédito habitacional/PIB ainda é reduzida se comparada a outros países, resultado das últimas duas décadas que não apresentaram uma condição favorável a oferta de crédito e ao nível de renda da população com potencial para a compra de residências.

No gráfico a seguir, onde estão apresentadas as relações entre o estoque de crédito imobiliário e o Produto Interno Bruto (PIB) em 2005, pode-se notar que o Brasil apresenta a menor taxa, equivalente a apenas $2,1 \%$, mesmo quando comparada a países da América Latina como México e Chile. O indicador estoque de crédito imobiliário/ PIB representa o saldo total das operações dos sistemas financeiros de cada país sobre o PIB do ano em questão. Como referência, em dezembro de 2008, 
este indicador no Brasil se manteve em 2,1\%. Até o momento da elaboração deste trabalho o PIB do último trimestre de 2009 ainda não tinha sido divulgado, no entanto a projeção é que este indicador tenha terminado o ano em 2,9\%. Diante da participação do crédito imobiliário no PIB de países com uma economia em estado de desenvolvimento mais avançado que a brasileira, é notável o potencial de crescimento do mercado residencial nacional.

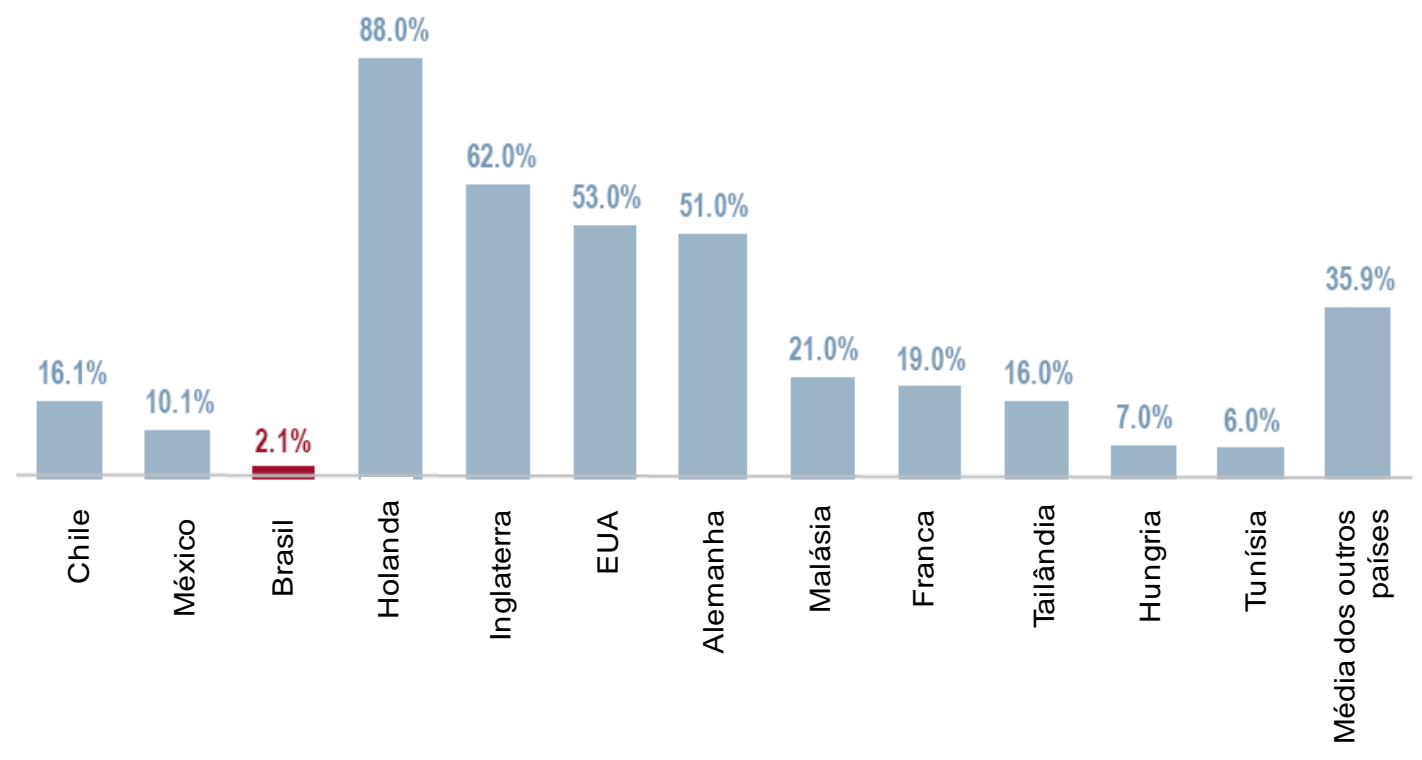

Gráfico 2 - Estoque de Crédito Imobiliário/ PIB 2005

Fonte: Banco Mundial

Observando o número de unidades financiadas no Brasil a partir de 1998 pode-se inferir que o mercado alternou momentos de alta e baixa, sendo que na média foram financiadas anualmente 328 mil unidades. Enquanto isso, no mesmo período, de acordo com os dados da PNAD, a FORMAÇÃo DOMICÍlIOS se manteve acima de 500 mil unidades. De acordo com as características do bem habitação citadas anteriormente, existe uma forte relação entre unidades financiadas e produzidas, podendo-se utilizar este parâmetro como indicador do nível de atividade da produção $^{8}$. Dessa forma, analisando o histórico brasileiro, tem-se que outras variáveis

\footnotetext{
${ }^{8}$ É possível inferir este comportamento uma vez que sem acesso a crédito (i) o consumo das unidades habitacionais fica restrito a pequena parcela da população com poupança acumulada equivalente ao preço da habitação e (ii) a produção fica restrita aos empreendedores com disponibilidade de recursos próprios suficientes para fazer frente à totalidade dos investimentos exigidos na produção.
} 
influenciaram no descolamento entre a FormAÇÃo DE DOMICÍlIOS e a PRODUÇÃo HABITACIONAL PRIVADA.

Explorando este tema, a elaboração deste trabalho se justifica pela contribuição ao estudo dos movimentos do mercado de EMPREENDIMENTOS IMOBILIÁRIOS HABITACIONAIS a partir de uma análise das condições históricas do mercado da cidade de São Paulo. Além disso, ao longo do texto pretende-se fornecer mais elementos de análise ao comportamento da demanda pela produção de unidades, a fim de aperfeiçoar o planejamento operacional dos agentes envolvidos no setor, como por exemplo, o posicionamento estratégico e dimensionamento da estrutura operacional e de capital dos agentes produtores.

A escolha do mercado paulistano se justifica pela disponibilidade de dados sobre a PRODUÇão HABITACIONAL PRIVAdA para a elaboração da pesquisa e pela representatividade desta capital no cenário nacional.

\subsection{OBJETIVOS}

O objetivo deste trabalho é identificar e interpretar as causas do descolamento entre a Produção Habitacional Privada e a Formação de Domicílios na cidade de São Paulo no período de 1998 a 2008 por meio da análise das VARIÁVEIS CONDICIONANTES selecionadas a partir da revisão bibliográfica do tema demanda habitacional.

\subsection{DELIMITAÇÃO DO TRABALHO}

O objetivo do trabalho não é discutir política social ou intervenções estatais necessárias para solucionar o problema da população com renda insuficiente para ter acesso à moradia. Além disso, a dinâmica e as variáveis desse segmento de menor renda estão distantes da lógica do mercado de EMPREENDIMENTOS IMOBILIÁRIOS HABITACIONAIS tratados neste trabalho por dependerem fortemente de financiamento subsidiado para o consumidor final. Dessa forma, as análises deste trabalho estão 
concentradas na Produção Habitacional PRIVAdA direcionada as famílias com capacidade de comprometimento de renda suficiente para financiar um imóvel dentro dos limites do SFH.

\subsection{DESENVOLVIMENTO DO TRABALHO}

O desenvolvimento do trabalho foi estruturado em três etapas de acordo com o esquema apresentado na figura 1.

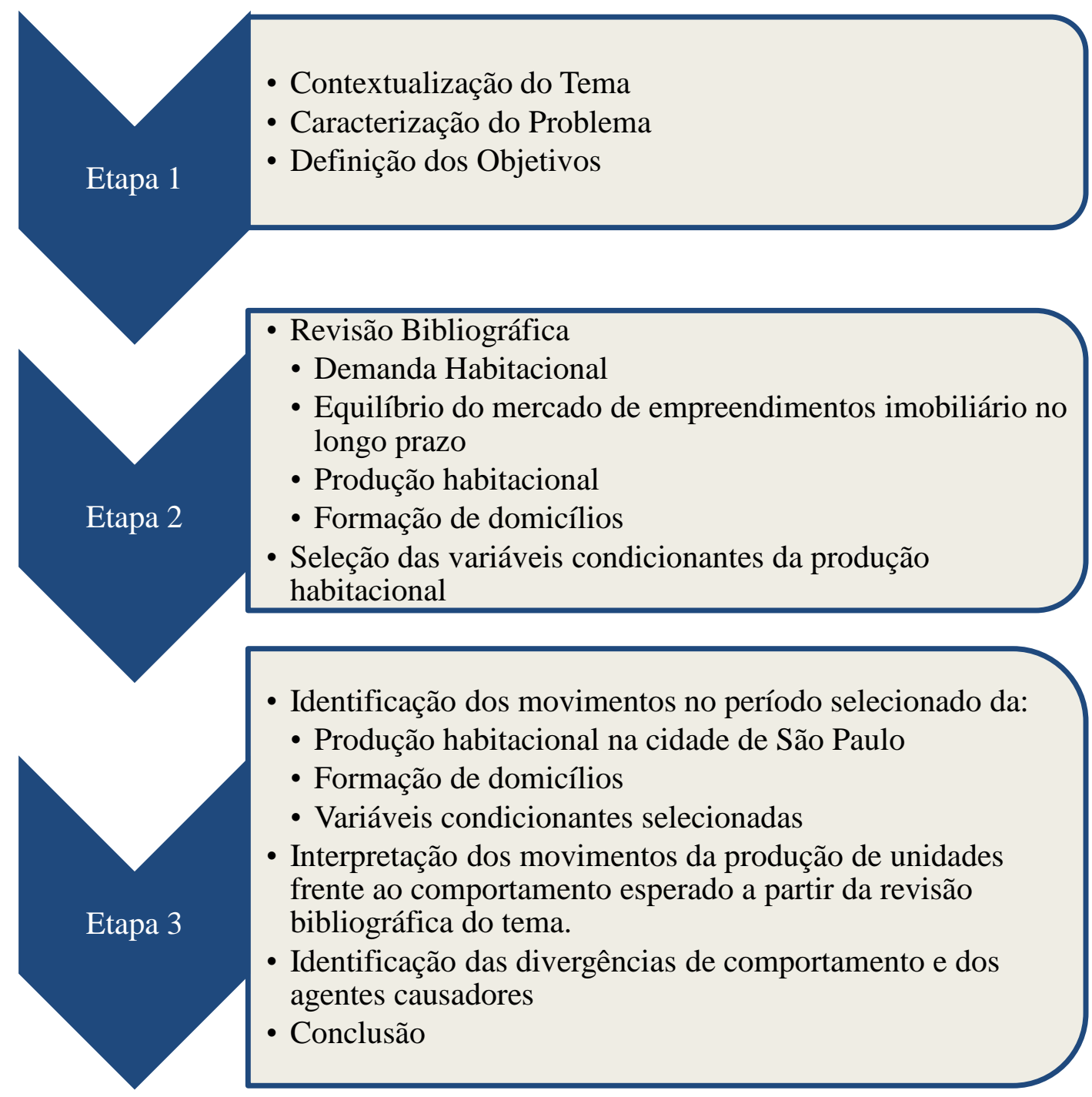

Figura 1- Desenvolvimento do trabalho 


\section{Etapa 1}

A importância do tema, bem como a caracterização do problema e a delimitação dos objetivos estão detalhados na etapa 1 .

\section{Etapa 2}

Na segunda etapa, é realizada uma revisão bibliográfica com o objetivo de identificar o estágio atual do conhecimento referente à DEMANDA HABITACIONAL e o equilíbrio do mercado de EMPREENDIMENTOS IMOBILIÁRIOS no longo prazo.

Na seqüência é apresentada a estrutura da produção habitacional a fim de verificar as modalidades existentes no mercado brasileiro. A revisão bibliográfica está concentrada nas publicações relevantes sobre o assunto divulgadas no meio acadêmico. Ainda nesta etapa, com base na bibliografia pesquisada, são selecionadas as variáveis condicionantes da demanda pela ProduÇão Habitacional PrivadA e o seu comportamento típico de acordo com a experiência dos pesquisadores nos ambientes econômicos estudados.

\section{Etapa 3}

Na Etapa 3, é apresentado o incremento de domicílios no período. Uma vez que não existem séries históricas de medições da FORMAÇÃO DE DOMICÍLIOS na cidade de São Paulo disponíveis nos institutos de pesquisa, foi necessária a pesquisa das metodologias de projeção existentes no meio acadêmico e a seleção da mais adequada para a obtenção do incremento de domicílios no período. Nesta etapa do trabalho foi utilizada a base de dados desagregados do Instituto Brasileiro de Geografia e Estatística (IBGE) e das projeções realizadas pelo Centro de Desenvolvimento e Planejamento Regional (CEDEPLAR) elaborada de acordo com a metodologia exposta no item 4.1

Os dados referentes ao comportamento da PRODUÇão Habitacional PRIVADA na cidade de São Paulo e evolução do PREÇO foram baseados nas publicações do Sindicado da Habitação de São Paulo (SECOVI-SP) e complementados com dados das empresas privadas de pesquisa GEOIMÓVEL e EMBRAESP. As referências 
bibliográficas estrangeiras pesquisadas recorrem comumente aos registros de alvarás de construção concedidos pelas prefeituras, no entanto, esse dado no Brasil, de forma geral, não está disponível com o detalhamento necessário. Devido à oportunidade de associar preço das unidades ofertadas, segmentação, equação de fundos dos empreendedores e agentes envolvidos, optou-se neste trabalho por utilizar esta fonte de informação. Buscando tratar a base de dados livremente, os resultados foram apresentados de forma sintética ao longo do trabalho.

Os dados referentes às demais variáveis condicionantes selecionadas: OFERTA DE Recursos, Gastos COM SERviçOS Habitacionais, RENDA e TAT são divulgados pelo IBGE, Associação Brasileira das Entidades de Crédito Imobiliário e Poupança (ABECIP) pelo Banco Central do Brasil (BACEN) e Federação das Indústrias do Estado de São Paulo (FIESP).

A partir dos dados coletados é analisado o comportamento da produção habitacional frente às variáveis condicionantes selecionadas. Considerando o descolamento entre as unidades financiadas e a formação de domicílios no Brasil nas últimas décadas, é esperado que o comportamento da produção habitacional na cidade de São Paulo não reproduza o mesmo comportamento descrito nas referências bibliográficas pesquisadas.

De acordo com o observado nos países desenvolvidos, os quais serviram como base para o desenvolvimento dos modelos de projeção de demanda habitacional presentes nas publicações acadêmicas sobre o tema, a produção de unidades irá acompanhar a formação de domicílios. Seguido do incremento da demanda haverá uma pressão nos preços do produto habitacional, os quais irão deflagrar o aumento da produção habitacional, aumentando assim a oferta. Influenciado por esse aumento da oferta, os preços iniciarão uma retração, resultando assim na redução da produção de unidades e no equilíbrio do estoque do sistema no longo prazo.

Dessa forma, considerando o descolamento histórico da realidade brasileira mencionado anteriormente, é realizada a interpretação dos movimentos da produção 
habitacional da cidade de São Paulo buscando identificar os agentes responsáveis por não confirmar essa tendência cíclica a partir da variável PREÇO. Como resultado dessa análise, é caracterizada a dinâmica do comportamento particular das variáveis condicionantes selecionadas na realidade nacional, buscando os fatores responsáveis por essas perturbações.

O comportamento relativo das variáveis condicionantes selecionadas frente à Produção Habitacional Privada será identificado por meio do cálculo do coeficiente de correlação de Pearson aplicado a série histórica anual de 1998 a 2008.

O coeficiente de correlação das variáveis calculadas será classificado neste trabalho da seguinte forma:

Entre 0 e 0,3: $\quad$ Positiva fraca

Entre 0,31 e 0,7: Positiva moderada

Entre 0,71 e 1,0: Positiva forte

Entre 0 e - 0,3: Negativa fraca

Entre -0,31 e -0,7: Negativa moderada

Entre -0,71 e -1,0: Negativa forte 


\section{A ESTRUTURA DA DEMANDA HABITACIONAL}

2.1. Abordagem tradicional do estudo da demanda habitacional

O tema DEMANDA HABITACIONAL é tratado tradicionalmente segundo certas premissas relacionadas à: (i) a natureza da commodity habitação, (ii) teoria do consumidor, e (iii) mercado habitacional. Segundo OLSEN (1969), a tomada de decisão dos consumidores desse mercado não é voltada para a unidade habitacional e sim para os SERVIÇOS HABITACIONAIS ${ }^{9}$. Nesse processo, os consumidores dos SERVIÇOS HABITACIONAIS tendem a maximizar a utilização de seus recursos, utilizando sua renda para satisfazer suas necessidades de acordo com a melhor alternativa disponível no mercado. Dessa forma, os SERviçOS HABITACiONAIS são tratados como uma commodity homogênea, excluindo assim a característica heterogênea das unidades habitacionais que devem ser destacadas em uma abordagem microeconômica do assunto. A última premissa considerada é a simplificação dos movimentos do mercado habitacional, admitindo que este seja perfeitamente competitivo e equilibrado.

Seguindo essas premissas, a DEMANDA HABITACIONAL é tratada macroeconomicamente, considerando que o mercado se equilibra internamente em função dos movimentos da economia. Por sua vez, o estudo dos movimentos internos do mercado habitacional está focado no comportamento individual do consumidor, nos preços heterogêneos das habitações, nos critérios de tomada de decisão, na localização e na percepção dos atributos de qualidade. As diferenças entre as abordagens microeconômicas e macroeconômicas estão sintetizada na tabela a seguir:

\footnotetext{
${ }^{9}$ Os SERVIÇOS HABITACIONAIS representam os gastos mensais de um chefe de família envolvendo a habitação. Conforme tratado nas literaturas estrangeiras pesquisadas, estes gastos são representados por um aluguel teórico calculado em função do valor do imóvel, dos custos de financiamento e da taxa de remuneração que investidores de imóveis esperam ganhar na locação. Esta abordagem tem o objetivo de simplificar a análise do impacto dos custos de um chefe de família envolvendo a habitação.
} 
Tabela 1 - Abordagens do tema Demanda Habitacional

Microeconômica

Macroeconômica

- Teoria do Consumidor

- Comportamento individual

- Critérios de tomada de decisão

- Percepção dos atributos de qualidade

- Preço heterogêneo das habitações
- Habitação = commodity homogênea

- Tomada de decisão: serviços habitacionais

- Maximização da utilização dos recursos

- Equilíbrio interno do mercado

- Mercado perfeitamente competitivo

Uma vez que este trabalho está focado no estudo da demanda pela ProDUÇão HABITACIONAL, independentemente dos atributos de qualidade que o produto necessite conter para atingir o público consumidor, a seguir será detalhada a abordagem macroeconômica. Pode ser encontrado em GIBLER; NELSON (2003) uma extensa revisão sobre o comportamento individual do consumidor no mercado imobiliário. O tema planejamento do produto habitacional para atender os anseios do consumidor é tratado em ROCHA LIMA JR (1993).

O comportamento da DEMANDA HABITACIONAL, segundo a abordagem macroeconômica descrita anteriormente, é generalizado segundo o comportamento da Renda, Preço, Gasto com Serviços Habitacionais e Características DEMOGRÁFICAS e pode ser representado a partir da seguinte equação:

$E Q(1) D(U, X 1, Y, P)=S$

(Equação geral da Demanda Habitacional)

D: DEMANDA HABITACIONAL;

U: GASTOS COM SERVIÇOS HABITACIONAIS;

X1: CARACTERÍSTICAS DEMOGRÁFICAS;

Y: RENDA;

P: PREÇO do produto habitacional;

S: Estoque do Produto Habitacional; 
Devido às suas características, o produto habitacional contém dois componentes de demanda distintos: a oferta e demanda pela sua locação, e a oferta e demanda pela sua aquisição. Neste caso, seguindo a definição apresentada anteriormente, os SERVIÇOS HABITACIONAIS representam a utilização do ativo imobiliário pelas famílias, que dependendo do custo de oportunidade, dos custos do financiamento e das condições de renda optarão por locá-lo ou adquiri-lo. Do ponto de vista do mercado produtor da habitação, a existência da demanda pelos SERVIÇOS HABITACIONAIS irá regular a sua atividade, uma vez que, independentemente do agente comprador do ativo imobiliário, seja ele a própria família usuária do imóvel ou o investidor que irá locálo posteriormente, haverá a FORMAÇÃo Dos DOMICÍlIOS que, por sua vez, representa a DEMANDA Habitacional.

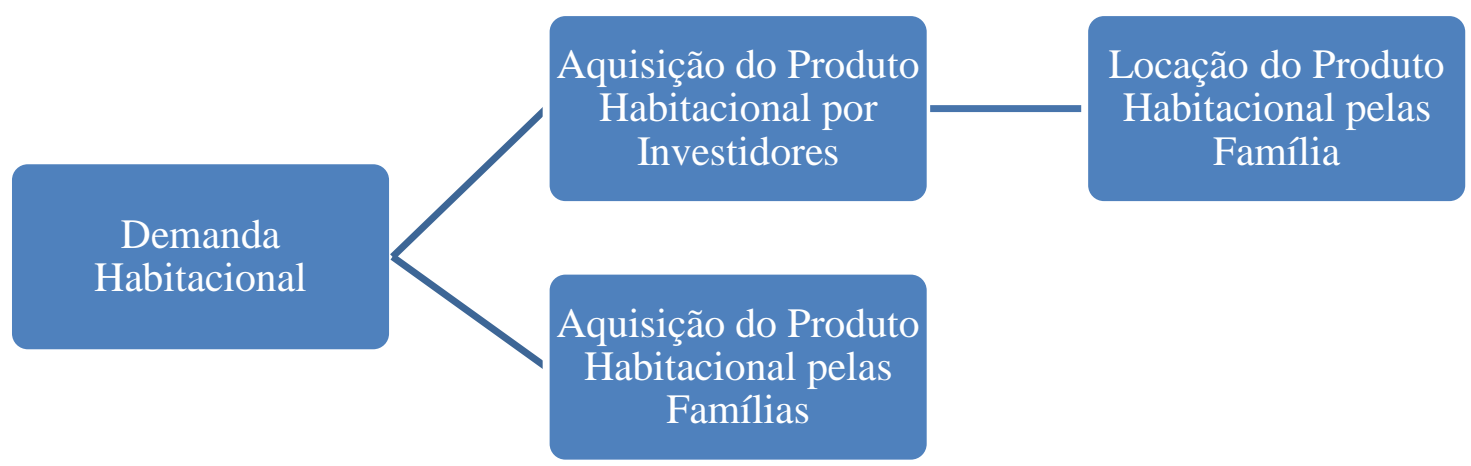

Figura 2- Estrutura da DEMANDA HABITACIONAL

Esta abordagem que aproxima a FormAÇÃo DE DOMICÍlios da DEMANDA HABITACIONAL segregando as famílias que irão alugar e adquirir o imóvel pode ser encontrada em NOLL et al (1997). Nesta literatura é apresentado o Modelo Florida de projeção de demanda habitacional que foi derivado da equação geral da demanda habitacional apresentada anteriormente.

Além da componente da formação de novos domicílios, a demanda habitacional ainda teria uma parcela de demanda do público que deseja se mudar geograficamente ou para um imóvel maior ou menor, deixando o anterior vago, onde apesar da produção habitacional ser incentivada haveria o aumento da taxa de vacância. No entanto, 
considerando o estágio de incremento populacional que o Brasil experimentou, podese inferir que essa componente exerce menor influência na produção habitacional que a do incremento de novos domicílios.

Vale ressaltar que essa particularidade brasileira não é reproduzida em outras economias, onde esta parcela representa uma importante componente da demanda pela produção. Como exemplo, é possível citar a média brasileira de mudanças ${ }^{10}$ de domicílio por pessoa ao longo do ciclo da vida em 1,8 vezes, no México este número é de 4 vezes e no G7, composto por Estados Unidos da América, Canadá, França, Alemanha, Itália, Japão e Inglaterra, é de 9 a 10 vezes. Considerando esse comportamento, a DEMANDA HABITACIONAL será tratada a seguir como uma função direta da FORMAÇÃO DE DOMICÍLIOS.

O comportamento da demanda no mercado de investimento pelo ativo imobiliário é regido pela atratividade da remuneração oferecida ao investidor. Este mercado está focado na parcela da demanda que não é capaz de contrair o financiamento imobiliário para a compra do imóvel ou que tenha um planejamento ou necessidade pessoal diferente. Conforme discutido em MACLENNAN(1979), o equilíbrio deste mercado tende a depender da taxa de remuneração de investimentos com perfil de risco semelhantes, ou simplesmente TAXA DE ATRATIVIDADE, da oferta de imóveis para locação e do custo de locação.

Tanto a aquisição do Produto Habitacional, a qual requer a contratação de FINANCIAMENTO HABITACIONAL, quanto a sua locação implicam em gastos. Estes estão computados na variável GASTOS COM SERVIÇOS HABITACIONAIS.

A maioria dos estudos referentes a este tema está em literatura estrangeira, geralmente em países com menores restrições ao crédito que o Brasil. Dessa forma, outra variável exógena ao mercado habitacional deve ser considerada como

\footnotetext{
${ }^{10}$ Os dados de média de mudanças de domicílio ao longo da vida foram compilados a partir de um trabalho elaborado pelo Wall Street Research. No entanto, não foi possível obter o trabalho original com a fonte de informação primária.
} 
condicionante da demanda: a OFERTA DE RECURSOS no mercado pelos agentes financeiros.

As CARACTERÍstiCAS DEMOgRÁFICAS concentram qualidades como perfil de idade da população, raça, estado civil, composição familiar e captura as tendências e necessidades do público consumidor gerador da demanda. Esta variável irá determinar a demanda por domicílios e é tratada detalhadamente no capítulo 3.3.

A RENDA da população determinará a sua capacidade de pagamento para a aquisição ou locação do imóvel. Esta variável, que está ligada as condições econômicas da sociedade, mede a produção de riquezas e desenvolvimento da sociedade. É na análise desse aspecto que se observa a formação do déficit habitacional, que, em uma condição de aumento na formação de domicílios descompassada da renda dos chefes de família capaz de suportar os GASTOS COM SERVIÇOS HABITACIONAIS, leva a inadequação habitacional.

O PREÇO do produto habitacional está ligado primariamente ao custo do terreno e de produção somados a margem de lucro do empreendedor no desenvolvimento daquele projeto. $\mathrm{O}$ custo do terreno trará implicitamente a valorização do entorno bem como os serviços disponíveis na região e, junto com conceitos de produto e arquitetura, formam a parcela intangível do PREÇO. Por último, os componentes da oferta e demanda determinarão o último condicionante da formação do PREÇO.

Seguindo a abordagem macroeconômica, tem-se como premissa o equilíbrio do mercado, que será dado pela adequação do orçamento dos chefes de família aos Gastos COM SERviço Habitacional. Dessa forma, as famílias tenderão a se adequar no espaço geográfico de acordo com sua capacidade de pagamento da locação ou do FinANCIAMENTo HABITACIONAL. Por último, tem-se o EstoquE ${ }^{11}$ como resultado da interação do conjunto das variáveis citadas.

\footnotetext{
${ }^{11}$ O ESTOQUE se refere ao total de domicílios no espaço geográfico estudado.
} 
2.2. Equilíbrio do mercado de empreendimentos imobiliários no longo prazo

A abordagem do estudo da DEMANDA HABITACIONAL adotando a premissa de equilíbrio tem origem na década de 60 , quando o estado norte americano necessitava de um instrumento capaz de prever investimentos no setor da habitação. Nessa época foram desenvolvidas equações baseadas nos modelos stock-flow, inicialmente utilizados no mercado financeiro conforme explorado por autores como MUTH (1960, 1985), WHITEHEAD (1971, 1974), KEARL(1979), MANKIN E WEIL(1989).

\subsubsection{O modelo Stock-flow}

O modelo Stock-Flow tem como premissa básica o equilíbrio instantâneo do mercado a partir da alteração de quaisquer das variáveis reguladoras do sistema. Essa premissa traz uma simplificação em relação ao comportamento real de mercado visto que, por exemplo, diferentemente de ações negociadas em uma bolsa de valores, os valores praticados em um mercado residencial necessitam de um período maior para se estabilizarem.

A equação que trata do incremento do estoque no modelo Stock-Flow é representada por:

$E Q(2) \Delta S=C(X 2, P)-\mu S$

(Incremento Stock-Flow)

$\triangle \mathrm{S}$ : INCREMENTO DO ESTOQUE;

C: Produção Habitacional;

X2: CUSTOS E DIVERSAS TAXAS DE JUROS;

$\mu$ : FATOR DE DEPRECIAÇÃO

Nota-se que, de acordo com a equação apresentada, o componente regulador do sistema é o preço dos imóveis e não há uma relação direta entre a DEMANDA HABITACIONAL apresentada na EQ(1) e o INCREMENTO No Estoque. Além disso, a simplificação de que a demanda habitacional é equivalente ao estoque introduz uma fragilidade ao modelo, não considerando a interação dos demais agentes no seu equilíbrio. 


\subsubsection{O modelo DW}

Em 1992, DIPASQUALE e WHEATON publicaram um modelo econométrico $\left(\right.$ Modelo $_{\mathrm{dw}}$ ) sofisticado, que reproduzia o comportamento do mercado de empreendimentos habitacionais, onde o principal objetivo era apresentar resultados capazes de contrapor as previsões de queda no valor dos imóveis do mercado norte americano.

O MODELO $_{\text {Dw }}$ pretende aproximar a dinâmica do mercado de moradias urbanas, tratando-as como ativos, analisando os equilíbrios temporários em cada período discreto de tempo, estudando como esses equilíbrios afetam os demais ao longo de uma trajetória. Dessa forma, a principal equação é semelhante a EQ(1) da abordagem tradicional, relacionando a DEMANDA HABITACIONAL (D) em função do número de FAMílias (H) e das seguintes variáveis: RENDA (Y), GASTOS COM SERVIÇO Habitacionais (U) e PReço do Produto Habitacional (P), sendo, a exceção desta última, todas exógenas ao mercado.

A seguir é exposto um diagrama adaptado de DIPASQUALE; WHEATON (1994) que relaciona a $\mathrm{EQ}(1)$ com os agentes internos ao mercado representados pelo Estoque em estudo (S), o VALOR DE LocAÇÃo praticado (R), PREÇO do Produto Habitacional (P), a Produção Habitacional (C), o InCREMENTo do Estoque $(\Delta \mathrm{S})$ e a DEPRECIAÇÃo Do ESTOQUE $(\mu)$. 


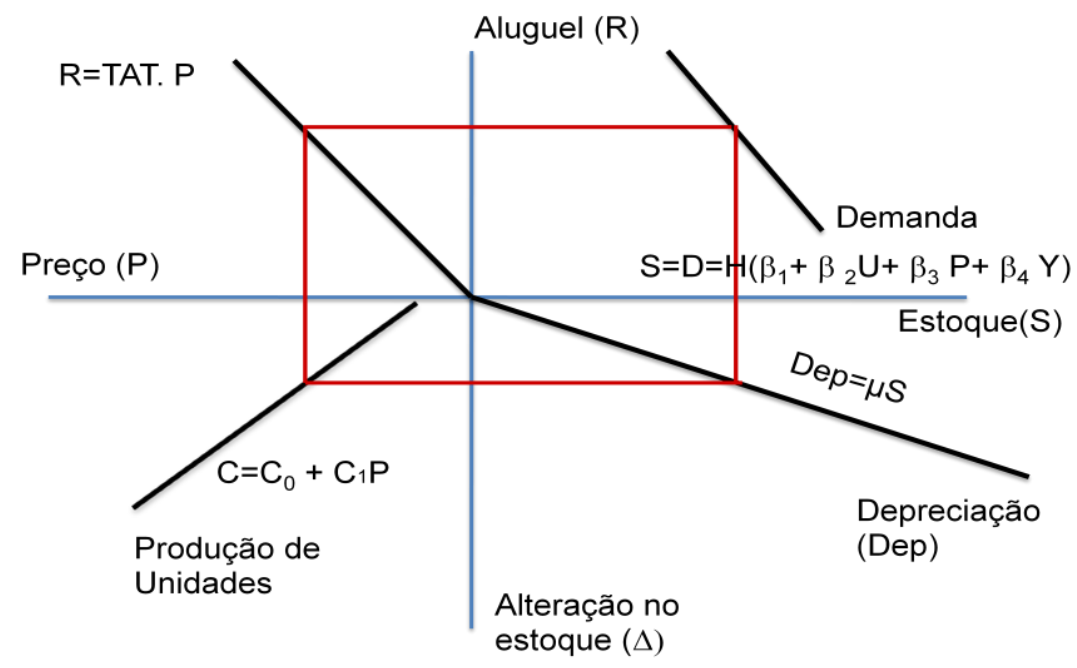

Figura 3- Diagrama MODELO DW

Fonte: DIPASQUALE, WHEATON(1994) com adaptações do autor

O modelo proposto por Dipasquale e Wheaton supõe que no equilíbrio de mercado a condição da DEmanda Habitacional se iguala ao Estoque do Produto HABITACIONAL. Dessa forma, haverá uma posição de equilíbrio nas demais variáveis (R,P,C, $\Delta S$, Dep), sendo que qualquer variação nas funções de comportamento de cada variável provocará uma nova posição de equilíbrio.

Dessa forma, de acordo com a Demanda Habitacional no mercado em estudo, haverá um nível no VALOR DE LOCAÇÃO. De acordo com a TAXA DE ATRATIVIDADE (TAT) exigida pelos proprietários dos imóveis na locação, estes são precificados em um nível de PreçO. A partir de determinado nível de PreçO dos imóveis $\left(\mathrm{C}_{0}\right)$ a produção se torna viável aos construtores do mercado, o que estimula a construção de novas unidades e gera um InCREMENTO nO Estoque $(\Delta S)$. Finalmente, depois de descontada a parcela do estoque inutilizada devido à depreciação das suas condições de uso, é obtido o nível do estoque do mercado em estudo.

A partir do modelo, pode-se notar a importância das variáveis exógenas: U, Y e H na dinâmica do modelo, visto que estas regem a inclinação da curva de demanda, e, portanto, influenciam diretamente o ponto de equilíbrio do mercado. 
Vale ressaltar que a delimitação da aplicação do modelo é referente ao corte geográfico que determina o mercado habitacional em estudo. Alguns determinantes econômicos podem ser comuns a todo o setor nacional, como, por exemplo, U. No entanto, variáveis como $\mathrm{Y}, \mathrm{P}, \mathrm{R}$ e $\mathrm{C}$ diferenciam-se de acordo com os subespaços urbanos.

Segundo DIPASQUALE E WHEATON (1996), em nível macro, um mercado habitacional pode ser definido como o espaço geográfico onde o agregado de unidades habitacionais e de terras urbanas é influenciado pelos mesmos determinantes. De acordo com essa conceituação, um agregado urbano pode ser uma cidade ou uma região metropolitana. Vale ressaltar que a delimitação dos espaços geográficos, para não apresentar viés, deve isolar o espaço em estudo de qualquer fonte de concorrência. Dessa forma, um bairro ou região de uma cidade não pode ser estudado seguindo este conceito.

Apesar das sofisticações do modelo quanto às peculiaridades do mercado residencial, ele apresenta algumas fraquezas. Estas são principalmente em relação à consideração da TAT como uma variável exógena ao modelo, não considerando que a dinâmica do próprio mercado habitacional possa interferir nessa variável.

A fim de refinar o modelo elaborado por DIPASQUALE E WHEATON e eliminar os pontos fracos, COWEL (2002) propõe algumas modificações em sua estrutura. O primeiro ponto abordado foi a questão da determinação do ponto de equilíbrio do sistema e conseqüentemente do mercado. Dessa forma, a equação que determina o equilíbrio do sistema, ou long-run Supply (LRS) como tratado na literatura original, é resultado da divisão da curva de construção pela curva de depreciação e pela curva do valor do aluguel e equivale a:

(1) $\mathrm{LRS}=\mathrm{C}_{0} / \mu+\left(\mathrm{C}_{1} /(\mu\right.$. TAT $\left.)\right) \mathrm{R}$ 
Graficamente, conforme demonstrado na figura abaixo, esta nova reta é obtida pelo traçado de dois retângulos que cruzam todas as curvas de comportamento, à exceção da curva da demanda. Unindo os vértices dos dois retângulos criados, tem-se a reta da LRS. A intersecção da curva da DEMANDA HABITACIONAL e da LRS determina o ponto de equilíbrio de mercado.

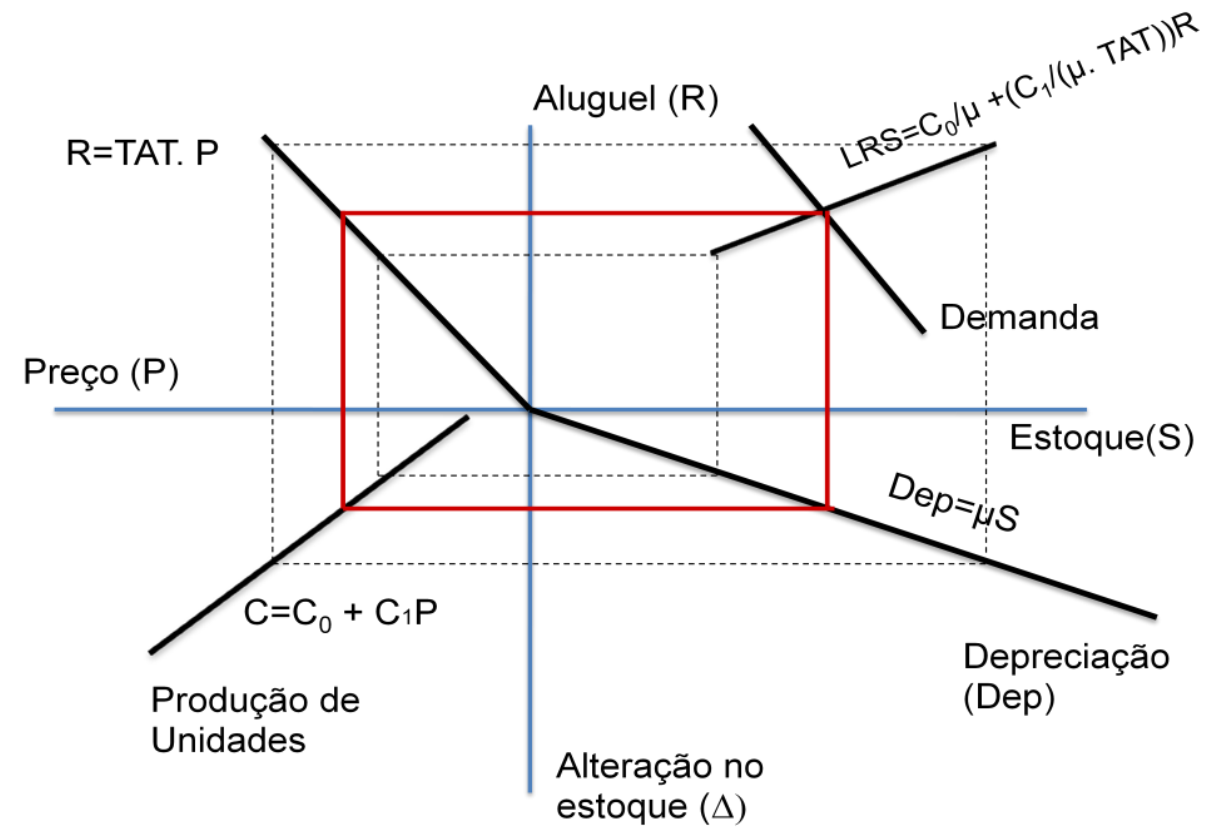

Figura 4- Determinação LRS

Fonte: COWEL(2002) com adaptações do autor

A partir da utilização da figura anterior, a interpretação do modelo se torna mais simples. Dessa forma é possível notar de forma clara o que aconteceria com a posição de equilíbrio no caso da alteração de quaisquer das condições de mercado.

$\mathrm{Na}$ tabela a seguir estão dados alguns exemplos de modificação nas condições do mercado residencial e seus efeitos nas demais variáveis. 
Tabela 2 - Modificações das condições de equilíbrio LRS

\begin{tabular}{l|lll}
\hline Comportamento em análise & LRS & Estoque & Aluguel \\
\hline Aumento na demanda (D) & Sem alteração & Aumento & Aumento \\
Aumento na Produção Habitacional (C) & Aumento & Aumento & Redução \\
Aumento na taxa de depreciação $\mu$ & Redução & Redução & Aumento \\
Aumento na TAT & Redução & Redução & Aumento \\
\hline
\end{tabular}

Dessa forma, pode-se observar que, um incremento na tendência da formação da DEMANDA HABITACIONAL por unidades residenciais, que seria representada por uma modificação na inclinação dessa reta, não causaria alteração na posição da reta da LRS. No entanto, o ponto de equilíbrio seria deslocado para uma posição à direita da escala de $\mathrm{S}$, o que representaria, na condição de equilíbrio, um aumento no estoque e no VALOR DE LOCAÇÃO.

No caso de um aumento na tendência da produção de unidades (C), a reta LRS teria sua inclinação alterada, resultando na intersecção com a reta $\mathrm{D}$ em uma posição de maior estoque. Esta condição representaria, na condição de equilíbrio, um aumento no ESTOQUE e conseqüentemente uma redução no VALOR DE LOCAÇÃo praticado no mercado.

A partir de um aumento na TAXA DE DEPRECIAÇÃO, a inclinação da reta da depreciação seria alterada, modificando também a reta LRS. Essa alteração resultaria em uma redução no ESTOQUE e conseqüentemente no aumento do VALOR DE LOCAÇÃO. Finalmente, o aumento na TAT, ou seja, a rentabilidade que os proprietários esperam da receita gerada pela locação de seus imóveis, resultaria na redução da inclinação da reta LRS, causando conseqüentemente a redução do ESTOQUE e o aumento do VALOR DE LOCAÇÃO.

Além de COWEL (2002), diversos autores propuseram a incorporação de outras variáveis no modelo, como custos com impostos, custos com manutenção, vacância, reserva de demanda, demanda especulativa. No entanto, a cada nova variável adicionada, a utilização e o ajuste do modelo se torna cada vez mais complexa. 


\subsubsection{A aplicabilidade do Modelo DW}

O ajuste do MODELo DW foi realizado no mercado norte americano a partir da regressão de uma série histórica anual com 40 observações das variáveis. A aplicação do modelo reproduziu o comportamento geral do território nacional, ilustrando o comportamento cíclico de preços e da produção de unidades. Conforme esperado, o modelo demonstrou a tendência de equilíbrio do mercado habitacional no longo prazo a partir da variável PREÇO.

A aplicabilidade do modelo vem sendo testada em outras economias. CHOW et al (2008) utiliza o ModeloDW nas cidades chinesas de Beijing, Tianjin, Shanghai, e Chongqing. $\mathrm{O}$ mercado chinês, diferentemente do americano, ainda não atingiu sua maturidade, sendo que há apenas 10 anos o estado liberou aos empreendedores a possibilidade de adquirir terrenos para o desenvolvimento de empreendimentos imobiliários. Os autores ajustaram o modelo utilizando dados desagregados trimestrais durante o período de 10 anos.

A aplicação demonstrou que o crescimento da variável PREÇO é positivamente influenciado pelo aumento da RENDA e negativamente influenciado pelo aumento do Estoque. Este estudo comprovou ainda que a PrODUÇão HABITACIONAL é negativamente influenciada pelo preço dos terrenos e pelo nível de atividade do mercado produtor no período anterior. Esse comportamento evidencia que a busca por terrenos tende a inflacionar os preços do setor, reduzindo assim a demanda futura. Mesmo apresentando estes resultados aderentes a premissa de comportamento do modelo, verificou-se incompatibilidades, principalmente na dinâmica da variável Gastos com Serviços Habitacionais. A aplicação do modelo indicou que um incremento nas taxas de financiamento não teria efeito direto no nível de preço praticado e na demanda. Essa incompatibilidade é resultado do histórico de intervenções políticas na oferta de crédito para o financiamento habitacional nas cidades estudadas. 
SANTOS e CRUZ (2000) apresentaram uma aplicação do modelo na Região Metropolitana de São Paulo (RMSP). A fim de trabalhar com dados suficientes para ajustar o modelo foram utilizados como fonte de dados as PNADS, o BACEN e a EMBRAESP e o período escolhido foi de 1977 a 1997. O resultado da aplicação demonstrou que uma elevação na TAXA DE ATRATIVIDADE, e, portanto, no custo de capital, reduz a Produção Habitacional. Tal qual no mercado chinês, o custo dos terrenos e o nível de atividade do mercado produtor influenciou negativamente a PRODUÇÃo HABITACIONAL.

Outro resultado importante alcançado foi o impacto da renda na demanda, a qual indica um comportamento cíclico do mercado habitacional. Neste caso, foi verificado que um aumento da renda pela demanda eleva o preço dos imóveis, que por sua vez, contribui para o incremento na oferta de novas habitações. No entanto, a partir da retração da renda, é observado o comportamento contrário. Apesar da aderência destas variáveis, a aplicação apresentou resultados divergentes do esperado com destaque para a demanda por habitações com elasticidade-preço maior que 1 . Neste caso a habitação seria caracterizada como um bem elástico, o que contradiz seu alto preço. O viés verificado pode estar relacionado ao descompasso entre a formação de domicílios no Brasil e a produção de unidades, que, no período estudado pode ter simulado a elasticidade-preço maior que 1 . É importante ressaltar que a qualidade da base de dados utilizada limita a interpretação dos resultados e para identificar os agentes perturbadores seria necessária a utilização de uma série histórica de dados desagregados consistente.

A causa das distorções apresentadas nos mercados da RMSP e das cidades chinesas pode ser atribuída à influência das variáveis exógenas ao modelo, como OFERTA DE Recursos, TAXa De Atratividade, FormaÇÃo de Domicílios e RENDA FAMILIAR. Vale destacar, como apresentado no caso do mercado chinês, a influência da política habitacional na oferta de crédito para o financiamento habitacional. Este fator se mostrou determinante na fragilidade da aplicação do modelo. 
Apoiado nos resultados obtidos pode-se inferir que a utilização do MODELODw em mercados em desenvolvimento não reflete o comportamento esperado conforme sua concepção inicial. Os resultados encontrados indicam que as variáveis exógenas ao modelo provocam alterações na dinâmica do mercado antes deste atingir seu equilíbrio.

O objetivo deste trabalho não é testar ou formular um modelo econométrico para prever o equilíbrio dos mercados habitacionais nem propor uma alternativa ao

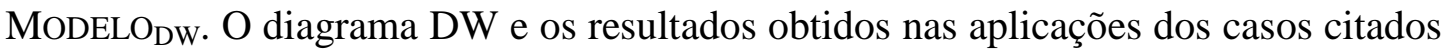
serão utilizados para auxiliar a interpretação das divergências de comportamento previstas verificadas na revisão bibliográfica entre os modelos de projeção de demanda apresentados e o observado na cidade de São Paulo entre 1998 e 2008.

\subsection{Variáveis condicionantes da produção habitacional}

Como resultado da revisão bibliográfica apresentada, pode-se dividir as variáveis condicionantes da demanda pela Produção HABITACIONAL em dois grupos: (i) VARIÁVEIS ENDÓGENAS e (ii) VARIÁVEIS EXÓGENAS.

Tabela 3 - Variáveis condicionantes da Produção Habitacional

\section{VARIÁVEIS ENDÓGENAS}

PREÇO

VALOR DE LOCAÇÃO

DEPRECIAÇÃO DO ESTOQUE

\section{VARIÁVEIS EXÓGENAS}

FORMAÇÃO DE DOMICÍLIOS

RENDA

GASTOS COM SERVIÇOS HABITACIONAIS

OFERTA DE RECURSOS

TAXA DE ATRATIVIDADE

Como visto nos estudos realizados, pode-se inferir que as VARIÁVEIS ENDÓGENAS: PREÇO e VALOR DE LOCAÇÃo irão se ajustar buscando o equilíbrio do sistema no longo prazo. No entanto, o sistema é influenciado pelo comportamento das VARIÁVEIS EXÓGENAS, que, conforme apresentado no item 2.2, em mercados que ainda não atingiram a maturidade, como é o caso brasileiro, afetam o seu comportamento mesmo antes de estes atingirem o seu equilíbrio. 
Conforme exposto, espera-se que a produção de unidades acompanhe a formação de domicílios. Seguido do incremento da demanda haverá uma pressão nos preços, os quais irão deflagrar o aumento da produção habitacional, aumentando assim a oferta. Influenciado por esse aumento da oferta, os preços iniciarão uma retração, resultando assim na redução da produção de unidades e no equilíbrio do estoque do sistema no longo prazo.

No entanto, conforme mencionado no item 1.2, esse comportamento não foi reproduzido no Brasil, onde ocorreu um descolamento entre a formação de domicílios e a produção de unidades. Apesar da literatura estrangeira não tratar explicitamente a oferta de crédito, seguindo o resultado da aplicabilidade do MODELODw em economias em desenvolvimento, tem-se que uma fonte de distorção significativa é a variável exógena OfERTA DE RECURSOS. A fim de cumprir o objetivo proposto neste trabalho, será interpretado nos próximos capítulos o descolamento entre a FORMAÇÃO DE Domicílios e a Produção Habitacional Privada. O descolamento será interpretado utilizando-se da observação das VARIÁveIS CONDICIONANTES selecionadas apresentadas no quadro a seguir juntamente com a premissa de comportamento preconizado na produção acadêmica pesquisada.

Tabela 4 - Premissa de comportamento das variáveis condicionantes selecionadas

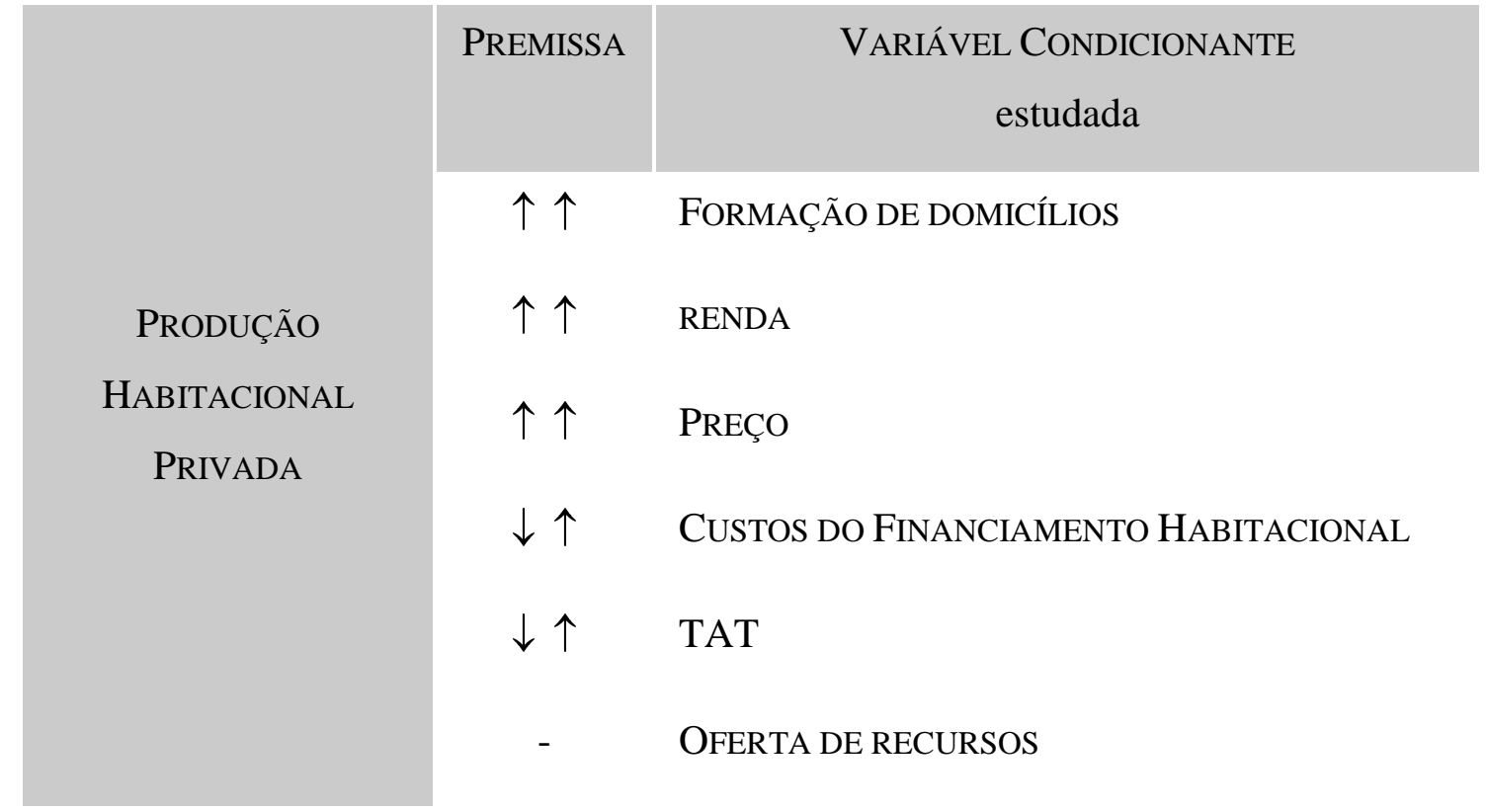


A variável GASTOS COM SERviçOS HABitAcionAis será tratada analisando as modificações dos Custos Do FinANCIAMENTO HABITACIONAL no período em estudo.

A variável depreciação do estoque não foi selecionada uma vez que é de difícil mensuração e comumente é tratada como uma constante na literatura. Considerando a inexistência de dados para realizar o estudo de sua influência na produção habitacional esta foi eliminada desta análise.

Não foi possível ter acesso a uma fonte de dados consistente dos valores de locação. Considerando o comportamento do mercado de investidores apresentado no item 2.4 (Figura 2) e sua relação com o PREÇO (figura 4), foi admitido neste trabalho que o VALOR DE LOCAÇÃo irá acompanhar o PREÇO e, portanto, também foi excluído da análise.

Conforme tratado em COWEL (2002) e por NOLL et al (1997) a quantidade de imóveis vagos pode reduzir a necessidade de produção de unidades habitacionais a partir do momento que estas estejam disponíveis para ocupação. No entanto, após pesquisa sobre o tema, foi possível identificar como fonte confiável apenas uma leitura em 2000 pelo IBGE, onde a proporção de imóveis vagos na cidade de São Paulo resultou em 14,25\% do estoque total de domicílios ou 402.807 unidades. Não foi possível verificar sua estratificação ou condição, como por exemplo, se estas estavam disponíveis para ocupação.

A mesma dificuldade de obtenção de dados foi encontrada pelos autores SERRA et al (2005) que em suas projeções utilizaram hipóteses de redução ou incremento dos imóveis vagos para produzir seus resultados. Considerando a limitação de dados e estudos disponíveis sobre esta variável, optou-se por excluir essa variável da análise e tratá-la como uma constante no período. Vale ressaltar que apesar de não ter sido avaliada neste trabalho, a evolução tecnológica, que vem aperfeiçoando desde os processos construtivos até a gestão empresarial e de capital dos agentes produtores, exerceu uma influência na produção habitacional privada no período. 


\section{PRODUÇÃO HABITACIONAL}

A partir do momento que a formação de domicílios supera o estoque disponível para ser ocupado, torna-se necessária a produção de novas unidades habitacionais. A seguir serão apresentadas as modalidades de produção habitacional no mercado de EMPREENDIMENTOS IMOBILIÁRIOS HABITACIONAIS brasileiro.

\subsection{Modalidades de produção habitacional}

Dependendo das características do público comprador e do ambiente de negócios, a produção pelos empreendedores se tornará mais ou menos atrativa influenciando diferentes modalidades produtivas. As modalidades de produção no Brasil, conforme exposto no Estudo Prospectivo da Cadeia Produtiva da Construção Civil (2002), podem ser divididas em:

(i) Produção Habitacional PRIVAdA: caracterizada pela atuação de EMPREENDEDORES IMOBILIÁRIOS responsáveis pela compra do terreno, desenvolvimento do produto, construção e venda ao consumidor final que pode ser desde a família de baixa até alta renda;

(ii) PRODUÇão PRÓPRIA: produção individualizada realizada por meio da contratação de pequenos construtores, atendendo um público predominantemente de alta e média renda. Geralmente os construtores recebem uma taxa de administração sobre o custo de construção;

(iii) AUTOCONSTRUÇÃO: construção usualmente informal realizada por famílias de baixa renda para uso próprio ou para venda;

(iv) ESTATAL: o estado é o gestor da produção com objetivos sociais; 
As modalidades (iii) AUTOCONSTRUÇÃO e (iv) ESTATAL tendem a satisfazer a demanda de famílias com baixa disponibilidade de comprometimento de renda e com dificuldade de acesso a crédito. Nestas modalidades de produção não há atratividade para que os empreendedores atuem sem recorrer a subsídios ou incentivos. Nestes casos, a RENDA dos chefes de família é insuficiente para promover a aquisição e por isso há a necessidade de subsídio ao comprador.

Nas modalidades (i) Produção Habitacional Privada e (ii) Produção Própria há espaço para que os EMPREENDEDORES IMOBILIÁRIOS utilizem recursos próprios ou do SFH para a produção de unidades habitacionais a uma remuneração ajustada ao risco do negócio. Os compradores são atualmente financiados, predominantemente, pelos recursos do SBPE, contido no SFH, e em menor parcela pelos recursos do Sistema Financeiro Imobiliário (SFI).

Dentro dessas modalidades de produção é formado o ambiente de negócio do mercado de EMPREENDIMENTOS IMOBILIÁRIOS HABITACIONAIS alvo deste trabalho.

3.2. O ambiente de negócio do mercado da Produção Habitacional Privada

A Produção Habitacional Privada tem como característica a necessidade de inserção do empreendimento no mercado para que o investimento seja viabilizado pelo empreendedor. Para atingir esse objetivo, o empreendedor deverá utilizar-se das melhores técnicas de planejamento de produto para atender aos anseios da demanda, superando seus concorrentes no mercado.

O ciclo de um empreendimento habitacional típico pode ser expresso de forma esquemática conforme a figura a seguir: 


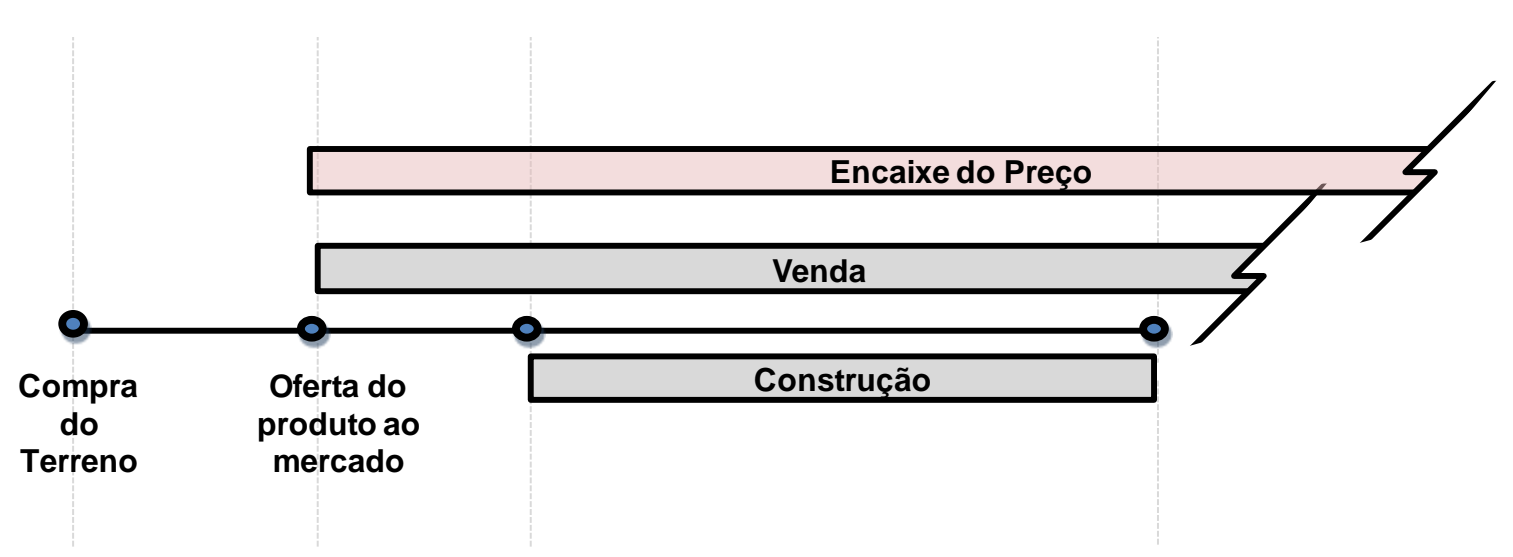

\section{Figura 5- Ciclo de um empreendimento habitacional}

Após a prospecção e compra do terreno para desenvolver o empreendimento para uma determinada demanda, o empreendedor iniciará a fase de planejamento do produto, realização dos projetos, orçamentos e aprovações legais junto aos órgãos competentes para disponibilizar seu produto a venda. Após oferecer seu produto ao mercado e iniciar a contratação de vendas o empreendedor usualmente acumula uma parte do PREÇO das unidades vendidas antes do início da construção a fim de reduzir sua necessidade de investimento.

Conforme observado na cidade de São Paulo no período selecionado, o restante do encaixe do PREÇO, por sua vez, se dará a partir da venda do restante das unidades e dos pagamentos realizados pelos compradores que desembolsam de $10 \%$ a $40 \%$ do valor da unidade até a entrega da construção. Uma vez que os custos de um empreendimento habitacional representam cerca de $80 \%$ do PREÇO, tem-se que existe uma grande necessidade de investimento durante o ciclo do projeto por parte do empreendedor.

Analisando um empreendimento protótipo na cidade de São Paulo, considerando um investimento no terreno de $10 \%$ a $20 \%$ do PREÇO, o empreendedor tem de forma paramétrica uma necessidade de investimento máxima no ciclo do projeto de $30 \%$ a $50 \%$ do PREÇO assumindo todos os custos envolvidos e os recebimentos dos compradores até a entrega do empreendimento. 
Conforme citado em ROCHA LIMA (1993), o empreendedor imobiliza seus recursos em insumos para desenvolver o empreendimento, perdendo assim liquidez. Dessa forma, somente haverá investimento a partir do momento que o empreendedor identifique o interesse em perder poder de compra com o objetivo de ganhar poder de compra no futuro quando receber o retorno.

Dessa forma, pode-se dizer que os empreendedores irão buscar no desenvolvimento de um empreendimento imobiliário um prêmio sobre o custo de oportunidade de seus recursos, exigindo assim uma TAXA DE ATRATIVIDADE mínima para realizar o negócio.

Para suportar a necessidade de investimento gerada, os empreendedores recorrem às instituições financeiras, que são os intermediários entre o aplicador dos recursos e o tomador, para promover a produção. No entanto, os recursos de FINANCIAMENTO À PRODUÇÃO somente são liberados ao empreendedor a partir de um determinado avanço de obra e uma parcela de vendas atingida de acordo com a exigência da instituição financeira. Além disso, o cronograma de desembolso do valor do financiamento pelos Agentes Financeiros é equivalente de $70 \%$ a $90 \%$ do custo de construção do empreendimento.

Dessa forma, o empreendedor continua tendo que suportar os custos do terreno, campanhas publicitárias e dos primeiros meses de construção para que o projeto seja realizado. Nesta nova configuração, contanto com o FinANCIAMENTO À PRODUÇÃo a necessidade de investimento do empreendedor é reduzida de $30 \%$ a $50 \%$ para $25 \%$ a $30 \%$ do PREÇO. Dessa forma, pode-se notar que em média a necessidade de investimentos de recursos próprios é reduzida em 43\%, exigindo a imobilização de capital do empreendedor por todo o ciclo do empreendimento, o que evidencia a ineficiência do mecanismo e a necessidade de recursos adicionais ao SFH para suportar a PRODUÇÃo HABITACIONAL PRIVADA.

Ao final da construção, os compradores irão recorrer a financiamentos de longo prazo para fazer frente ao restante do PREÇO que deverá ser encaixado. A partir deste 
momento, a operação muda de natureza e os empreendedores se utilizam de instrumentos financeiros para repassar a carteira de recebíveis dos compradores das unidades habitacionais aos AGENTES FINANCEIROS.

O repasse da carteira de recebíveis em sua maior parte é feita às instituições financeiras que operam os recursos do SBPE dentro do ambiente do SFH. Existem ainda os recursos de investidores no mercado de capitais que são acessados por meio do SFI com a emissão de Certificados de Recebíveis Imobiliários (CRI). Este tema será tratado detalhadamente no capítulo 5, no entanto, é importante ressaltar que o ciclo do empreendimento termina após o recebimento da última parte do encaixe do preço. Uma vez que a atividade de financiamento ao comprador por longo prazo possui riscos diferentes do ciclo de produção e da venda do produto habitacional, este papel é exercido por AGENTES FinANCEIROS com o perfil de risco e a equação de fundos adequada a esse tipo de negócio, otimizando assim o ciclo do empreendedor e a sua utilização de capital.

Dessa forma, ao utilizar o repasse da carteira de recebíveis, o prazo de encaixe dos recursos das vendas é reduzido, devolvendo a capacidade de investimento para o empreendedor desenvolver novos produtos.

Apenas como referência, de forma geral, o ciclo de um empreendimento habitacional na cidade de São Paulo está entre 18 e 42 meses. O ciclo depende essencialmente de (i) dificuldade da formatação do produto e obtenção das aprovações, que podem variar de 3 a 12 meses (ii) prazo de acumulação de parte do preço antes do início da construção, que pode variar de 0 a 12 meses de acordo com a estratégia traçada pelo empreendedor, (iii) prazo de construção, que varia de 6 a 24 meses dependendo da tipologia do produto (horizontal ou vertical) e da quantidade de unidades e (iv) finalmente do prazo para o encaixe da última parcela do PREÇO que vai depender da agilidade do empreendedor no repasse da carteira de recebíveis para os AGENTES FINANCEIROS. 
3.3. Identificação da produção de unidades na cidade de São Paulo no período selecionado

Seguindo as modalidades de produção apresentadas no item 3.1 e o objetivo do trabalho, a PRODUÇÃo HABITACIONAL apresentada adiante neste texto se refere à Produção Habitacional Privada, sem considerar a Produção PróPria, a AUTOCONSTRUÇÃO e a ESTATAL.

A identificação do volume da Produção Habitacional PRIVAda foi obtida a partir da coleta dos dados da nova oferta habitacional no momento em que ela foi disponibilizada ao mercado, antes mesmo do início de sua construção. Este dado apresenta claramente um descompasso com a formação de domicílios uma vez que, conforme mencionado anteriormente, da oferta do empreendimento até sua entrega tem-se como padrão de comportamento no mercado de empreendimentos imobiliários da cidade de São Paulo um prazo de 18 a 42 meses.

No entanto, devido à oportunidade de associar preço das unidades ofertadas, segmentação, equação de fundos dos empreendedores e agentes envolvidos, optou-se neste trabalho por utilizar esse dado como indicador da PRODUÇão HABITACIONAL considerando esse descompasso na análise dos resultados.

A importância do mercado da cidade de São Paulo frente ao cenário nacional pode ser representada pela participação de $12 \%$ no PIB brasileiro, conforme divulgado pelo

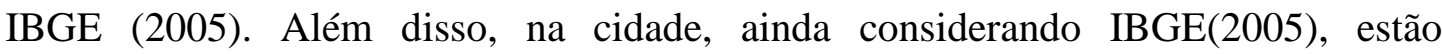
concentrados $6 \%$ dos domicílios e $7 \%$ da população do país.

Analisando a produção de unidades no mercado de Empreendimentos Imobiliários Habitacionais da cidade de São Paulo, tem-se o seguinte ciclo em número índice de 1998 a 2008. 


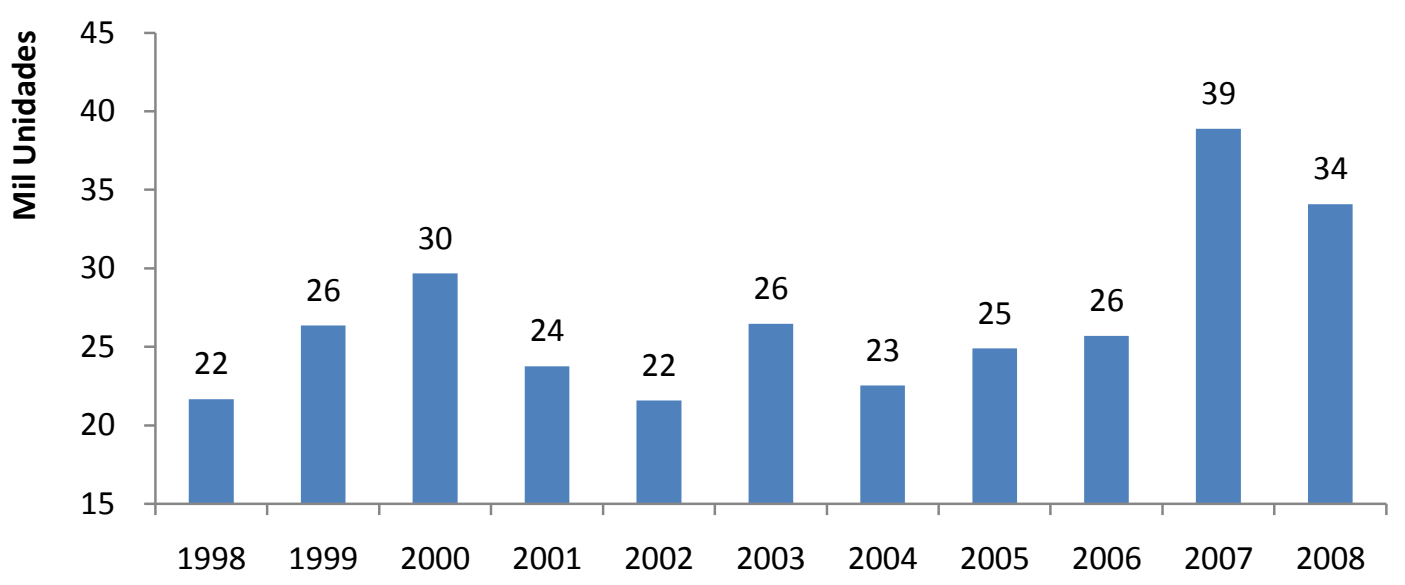

Gráfico 3 - Novas unidades habitacionais ofertadas na cidade de São Paulo Fonte: SECOVI-SP, GEOIMÓVEL, EMBRAESP com adaptações do autor

A fim de realizar comparações entre a produção habitacional e as variáveis em estudo, a mesma informação foi transformada em número índice de 1998 a 2008, sendo que a produção de 1998 representa o índice 100.

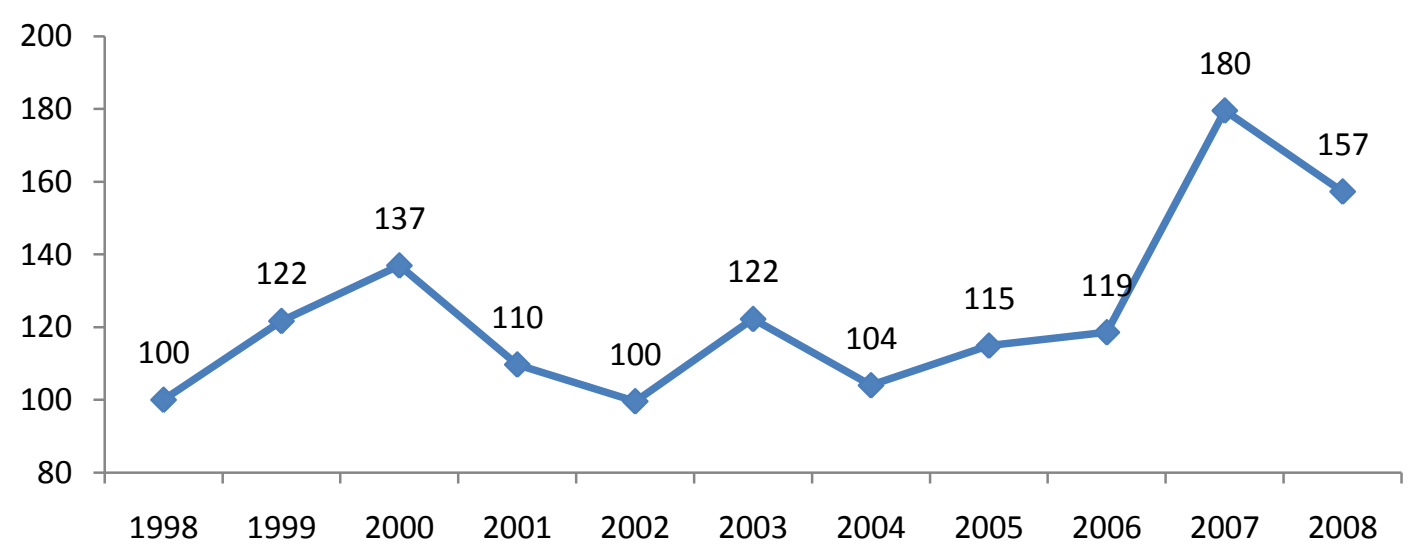

Gráfico 4 - Novas unidades habitacionais ofertadas na cidade de São Paulo $(1998=100)$

Fonte: SECOVI-SP, GEOIMÓVEL, EMBRAESP com adaptações do autor

A partir da observação do ciclo apresentado pode-se inferir que a PRODUÇÃo PRIVADA IMOBILIÁRIA apresentou três picos: em 2000, 2003 e em 2007. Neste último foi registrada uma alta muito acima do padrão dos anos anteriores. A fim de 
interpretar o descompasso da PRODUÇÃO HABITACIONAL mencionada anteriormente, a seguir será exposto o comportamento das demais variáveis selecionadas.

\section{FORMAÇÃO DE DOMICÍLIOS}

Seguindo o conceito apresentado no item 2.1, a DEMANDA HABITACIONAL possui dentre suas componentes a FORMAÇÃO DE DOMICÍlIOS, que no caso brasileiro representa a principal variável de influência na PRODUÇÃo HABITACIONAL. Uma vez que não existem dados suficientes para segregar o comportamento das demais componentes no período selecionado, a DEMANDA HABITACIONAL terá seu comportamento aproximado à FORMAÇÃO DE DOMICÍLIOS.

\subsection{Metodologias de projeção da Formação de Domicílios}

Conforme mencionado no item 1.4, uma vez que não existem medições disponíveis do incremento do número de domicílios, a fim de identificar a demanda no período selecionado se tornará necessário o estudo da estrutura da FORMAÇÃo DE DOMIĆ́LIOS e das metodologias de projeção utilizando os dados da PNAD e do CENSO.

Seguindo as premissas expostas no item 2.1 , dentre os elementos da estrutura da DEMANDA Habitacional, a Formação DE Domicílios exerce um papel fundamental visto que é sua variável básica. Segundo HAMILTON (2004), a discussão da formação de domicílios está centrada nas características da população e nas componentes de crescimento da mesma. As componentes podem ser segregadas em tamanho da população, estrutura etária e condições sócio-econômicas e culturais. Nesta última componente estão contidos os processos de transição, descontinuidade demográfica, mudanças e tendências da pirâmide etária.

Entre os métodos utilizados no estudo da formação de domicílios pode-se destacar a metodologia de (i) análise da densidade domiciliar e (ii) a taxa de chefia. No primeiro método, conforme tratado em FRIAS (1987), as componentes são traduzidas de forma 
simplificada, analisando a relação entre o tamanho da população e a quantidade de domicílios. Esta abordagem, no entanto, não permite avaliar o forte efeito da estrutura etária da população na formação de domicílios.

\subsubsection{A taxa de chefia}

O método (ii) taxa de chefia considera por sua vez, a composição da população por idade, sexo, estado conjugal, relação com o chefe do domicílios e outras variáveis que possam ter efeito significativo. Segundo BUCH (2000), o número de domicílios existentes em um determinado espaço geográfico é igual à quantidade de chefes de domicílios da população que ocupa esse mesmo espaço.

Essa metodologia permite classificar os domicílios em sucessivos grupos etários de $n$ anos segundo a idade do chefe do domicílio. Dessa forma, o total de domicílios no ano $t$ pode ser expresso pela seguinte equação:

$E Q(3) H(t)=\sum_{n} H_{x}(t)$

(Total de Domicílios)

$\mathrm{H}(\mathrm{t})$ : Número de Domicílios;

Para cada grupo etário $x$ a $x+n$ haverá um total de domicílios ocupados por indivíduos de acordo com a equação 4 a seguir:

EQ(4) ${ }_{n} \boldsymbol{H}_{\boldsymbol{x}}(\boldsymbol{t})={ }_{n} \boldsymbol{T}_{\boldsymbol{x}}(\boldsymbol{t})_{\boldsymbol{n}} \quad \boldsymbol{P}_{\boldsymbol{x}}(\boldsymbol{t}) \quad$ (Total de Domicílios por Grupo Etário)

${ }_{n} \mathrm{H}_{\mathrm{x}}(\mathrm{t})$ : Número de Domicílios por Grupo Etário;

${ }_{n} T_{x}(t)_{n}$ : Taxa de Chefia;

$\mathrm{P}_{\mathrm{x}}(\mathrm{t})$ : População por Grupo Etário;

$E Q(5) \quad{ }_{n} \boldsymbol{T}_{x}=\frac{{ }_{n} \boldsymbol{c}_{x}(t)}{{ }_{n} \boldsymbol{P}_{x}(t)}$

(Taxa de Chefia)

${ }_{n} c_{x}(t)$ : DOMICÍlIos ocupados CheFIAdOS POR INDIVÍDUOS DO GRUPo ETÁRIO DE X A X+N ANOS NO ANO T; 
Para utilizar as equações expostas acima é necessário projetar a taxa de chefia para cada projeção populacional. Usualmente é aplicada uma taxa constante para toda a amostra, o que pode resultar em uma fonte de erro significativa. RIOS NETO et. al. (2005) e GIVISIEZ et. al. (2006) propõe a taxa de chefia por meio de modelos de idade período coorte (MODELO IPC). Este modelo desagrega a TAXA DE CHEFIA de acordo com a idade, o período e cada coorte, projetando padrões de evolução destas três variáveis. A projeção do comportamento destes parâmetros foi realizada em RIOS-NETO e OLIVEIRA (1999) e em GIVISIEZ et al. (2006) adotando modelos lineares generalizados.

Comparando a projeção de recentes estudos realizados utilizando os modelos de densidade domiciliar e taxa de chefia, tem-se em LEON et. al. (2007) uma diferença de $5 \%$ para um horizonte de 10 anos e $10 \%$ para um horizonte de 20 anos no número total de domicílios. Nesta comparação o modelo de taxa de chefia apresentou resultados mais ajustados, seguindo as recomendações de aplicação sugeridas pela UNITED NATIONS (1973). Os dados citados se referem a projeções utilizando os dados dos censos de 1970, 1980, 1991 e 2000. Neste mesmo estudo é indicada a utilização de micro dados das PNADS devido à possibilidade de desagregar e acompanhar anualmente a evolução das variáveis, conferindo maior ajuste ao modelo.

\subsubsection{Adequação dos domicílios}

Dentro do número de domicílios formados existem parcelas de unidades habitacionais inadequadas ou em condições precárias de acordo com o tratamento de déficit habitacional publicado pela FJP (2006). Dessa forma, é necessário reconhecer o comportamento diferenciado desta parcela do incremento de domicílios isolando seu comportamento característico do movimento vegetativo do estoque habitacional adequado. 
Seguindo o objetivo deste trabalho, o estudo da formação de domicílios deve estar focado na parcela do incremento adequado, segregando assim o incremento do déficit habitacional ou de domicílios inadequados conforme as CARÊNCIAS HABITACIONAIS.

GIVISIEZ et. al. (2006) segrega a evolução dos domicílios segundo as CARÊNCIAS HABITACIONAIS, as quais são divididas da seguinte forma:

(i) SubstituiçÃo do Estoque:

a. Domicílios precários

i. Domicílios Rústicos: de acordo com IBGE, aqueles que não têm paredes em material durável (alvenaria ou madeira aparelhada). É estimado indiretamente pelo total de domicílios sem banheiro.

ii. Domicílios Improvisados: domicílio localizado em espaços não destinados exclusivamente a moradia ou em prédio em construção, embarcação, carroça, vagão, tenda, barraca, gruta, etc.

b. Domicílios estendidos: domicílios com mais de uma família

i. Famílias conviventes secundárias: As famílias conviventes secundárias constituídas por, pelo menos, duas pessoas ligadas por laços de parentesco, dependência doméstica ou normas de convivência e que residem em um mesmo domicílio junto com outra família denominada principal

ii. Famílias residentes em cômodos alugados e cedidos: os cômodos são "domicílios" particulares compostos por um ou mais aposentos localizados em casa de cômodos, cortiço, cabeça-de-porco, etc. Esta opção conceitual incorpora como coabitação disfarçada o pensionista, que é a pessoa que, sem ser parente, pagava hospedagem ou contribuía para as despesas de moradia e alimentação do domicílio. 
c. Alto comprometimento da renda com aluguel: famílias residentes em domicílios duráveis com até três salários mínimos de renda familiar, que dependem mais de $30 \%$ da renda com o aluguel

\section{(ii) ADEQUAÇÃO DO ESTOQUE:}

d. Carência de serviços de infra-estrutura: domicílios que não contam com pelo menos um dos serviços de infra-estrutura básica.

e. Adensamento excessivo: domicílios com mais de três pessoas por dormitório. Inclui os membros da família principal e das famílias secundárias.

f. Inadequação fundiária: casos em que pelo menos um dos moradores tem a propriedade da moradia, mas não possui a propriedade total ou parcial do terreno.

A projeção segundo as carências habitacionais é tratada formalmente segundo uma aplicação especial dos modelos lineares generalizados segundo o modelo multinomial representado na equação a seguir:

$$
E Q(6) \ln \left(\frac{\operatorname{Pr}\left(D_{d}\right)}{\operatorname{Pr}\left(D_{\text {ref }}\right)}\right)=\alpha_{r}+\theta_{r} I+\pi_{r} I+r_{r} C+\sigma_{r} \operatorname{Sexo}+\mu_{r} U F
$$

(Domicílios segundo inadequações)

$\operatorname{Pr}\left(D_{d}\right)$ : Probabilidade estimada de o domicílio pertencer à categoria de inadequação

I: Categoria de idade dos chefes de domicílio,

P: Categoria de períodos dos chefes de domicílios

C: Categoria de Coorte dos chefes de domicílio sexo: sexo dos chefes de domicílios UF: unidade da federação $\alpha_{\mathrm{r}}, \theta_{\mathrm{r}}, \pi_{\mathrm{r}}, \Upsilon_{\mathrm{r}} \sigma_{\mathrm{r}} \mu_{\mathrm{r}}$ : Parâmetros estimados para cada categoria de carência familiar

Finalmente, a diferença entre o movimento da formação de domicílios segundo as carências habitacionais e a formação total resulta nos domicílios adequados. Seguindo 
os objetivos deste trabalho, o comportamento da FORMAÇÃo DE DOMICílIOS será tratado segregando a parcela adequada, visto que esta é alvo do mercado de EMPREENDIMENTOS IMOBILIÁRIOS HABITACIONAIS. A evolução desta parcela é determinada com base nos dados disponíveis nas PNADS e na aplicação das equações 4 e 6 conforme apresentado em GIVISIEZ et. al. (2006) de onde foram extraídos os dados de incremento de domicílios utilizados neste trabalho.

Optou-se neste trabalho por não utilizar a formação de domicílios por faixa de renda uma vez que a base de dados utilizada considerou como referência o salário mínimo. Conforme citado em MEYER (2008), a oscilação do salário mínimo nas últimas décadas acima do índice de inflação produz distorções nas análises e, portanto, dificulta as conclusões e comparações na mesma base. Como referência, no período selecionado o IPCA acumulou uma alta de aproximadamente $101 \%$ enquanto o salário mínimo aumentou 219\%. As mesmas distorções utilizando a projeção de domicílios de acordo com o agrupamento de salários mínimos foi encontrado em SERRA et al (2005) e em BARROS (2009).

4.2. Comportamento da formação de domicílios na cidade de São Paulo no período selecionado

Para avaliar a formação de domicílios no período selecionado de 1998 a 2008 é necessário observar, além do crescimento da população, os componentes da dinâmica demográfica.

\subsubsection{A dinâmica da demografia brasileira}

As componentes da dinâmica demográfica podem ser dividias em: (i) fecundidade, (ii) mortalidade e (iii) migrações que interferem na distribuição da pirâmide etária dos potenciais chefes de família capazes de constituir uma residência.

Considerando a pirâmide etária elaborada pelo IBGE (2004) com base na distribuição da população em 1980, apresentada na Figura 5, tem-se que homens e mulheres até 
20 anos representavam a maior coorte da história brasileira. Projetando essa coorte para o período selecionado, tem-se que essa população teria entre 18 e 28 anos em 1998 e entre 28 e 48 anos em 2008.

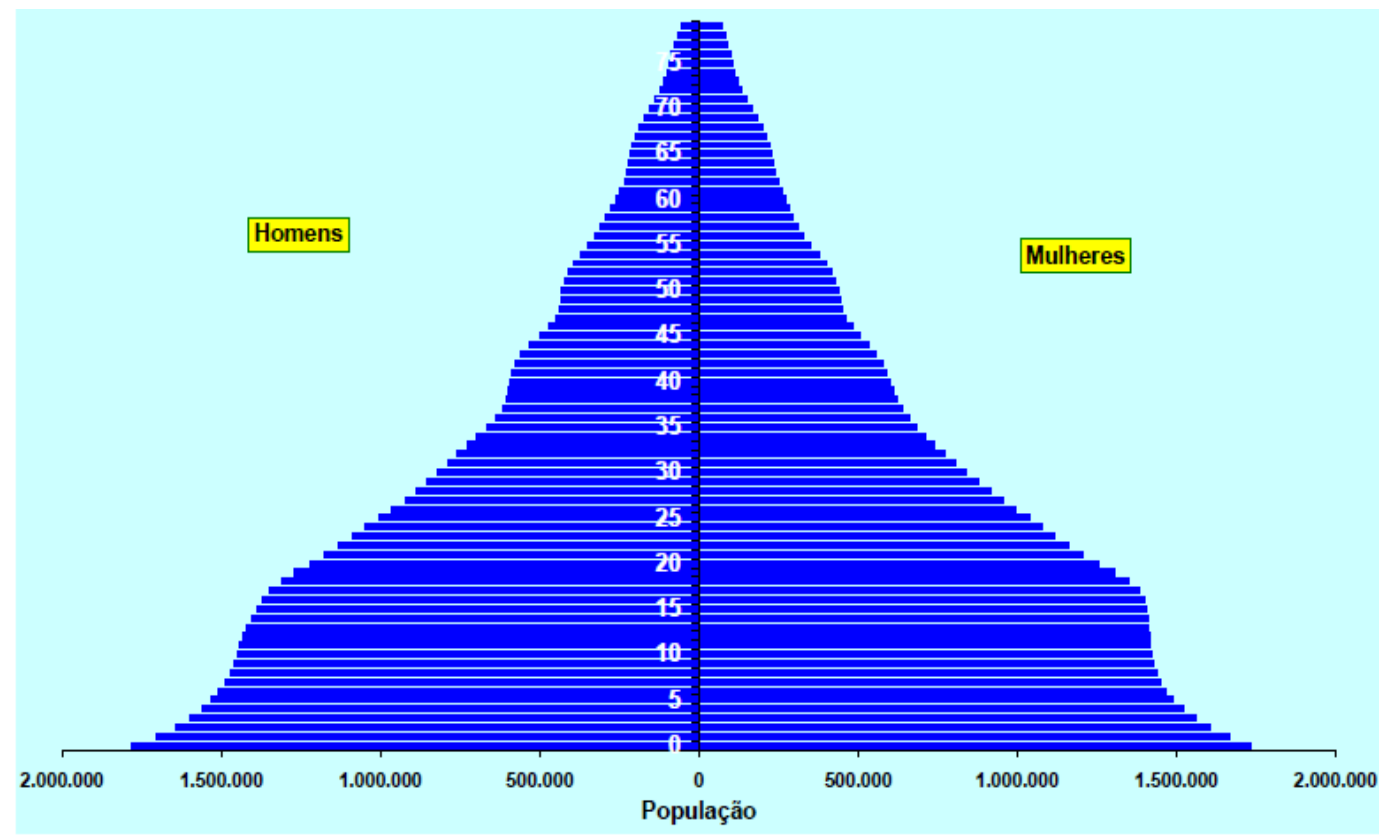

Figura 6 - Pirâmide etária da população brasileira em 1980

Fonte: IBGE 2004

De acordo com CAMARANO (2006) a constituição de domicílios na década de 80 estava associada à população entre 24 e 36 anos. Em 2000, essa faixa se estreitou para entre 24 e 28 anos. Considerando que os domicílios são formados por chefes de família entre essa idade, é possível inferir que o Brasil experimentou no período de 1998 a 2008 uma das maiores ondas de demanda por domicílio de sua história.

Ainda tratando das componentes da dinâmica demográfica, tem-se o fator da idade média ao casar, idade média ao primeiro e segundo filho, que são resultado das mudanças comportamentais das gerações e que influenciam no tamanho dos domicílios formados. Como observado no gráfico 5 , existe uma tendência de diminuição no tamanho médio dos domicílios desde a última década. Como exposto em GIVISIEZ et al (2006) o tamanho médio dos domicílios encontra-se próximo a 5,0 pessoas em países em desenvolvimento. Esse comportamento é similar aos países da Europa e América do Norte na metade do século dezenove. 


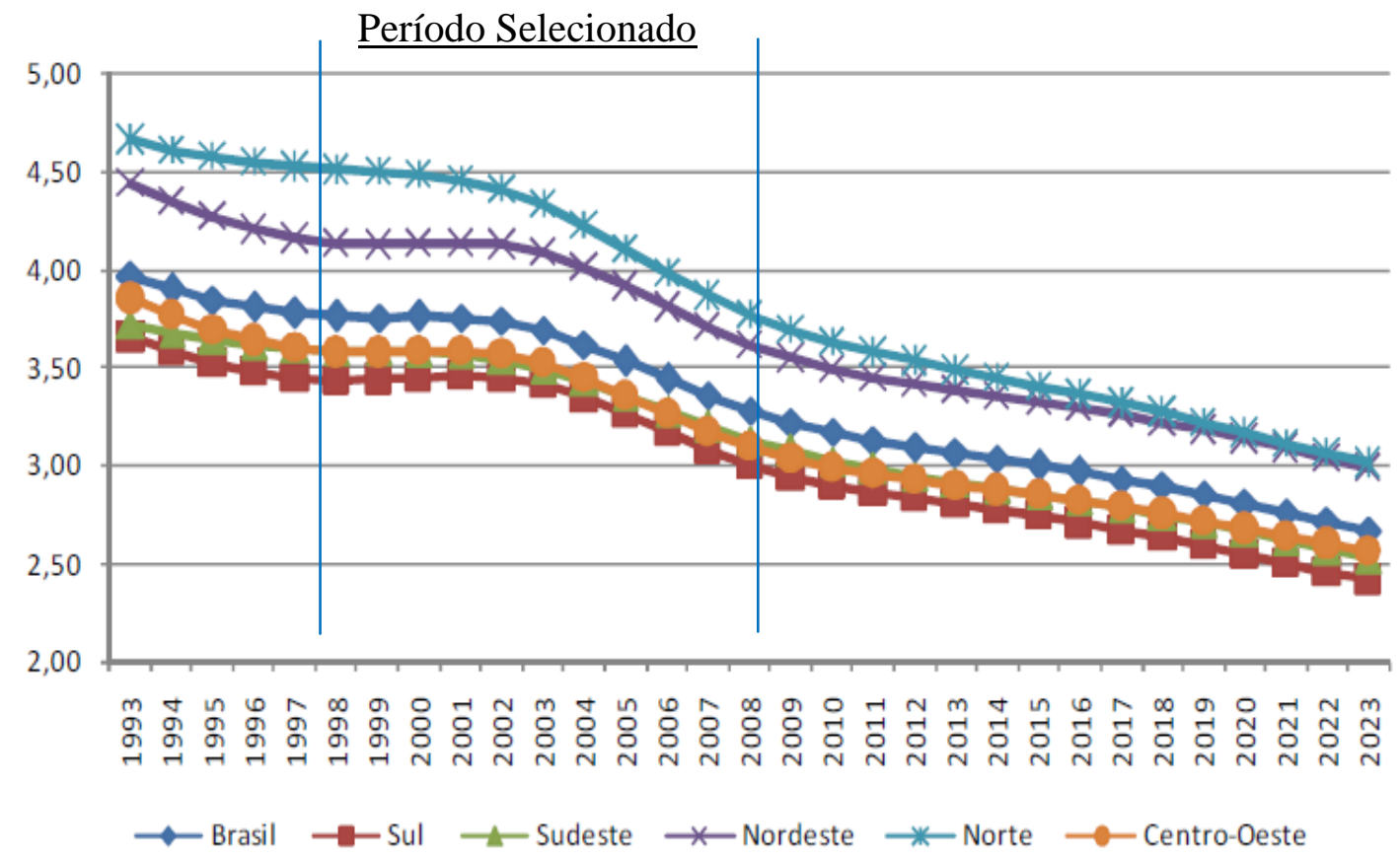

Gráfico 5 - Densidade média dos domicílios projetados segundo grandes regiões e Brasil entre 1993 e 2023 (habitantes/domicílios).

Fonte: PNAD (IBGE, 1982 a 2004). Projeção Populacional (CEDEPLAR,2007). Projeção Taxas de Chefia de Domicílio (CEDEPLAR,2007)

O gráfico 6 e os demais apresentados daqui em diante referentes à formação de domicílios utilizam dados projetados após 2003 de acordo com o método da taxa de chefia detalhado no item 2.3. De acordo com a projeção, o tamanho médio de domicílio em todas as grandes regiões brasileiras apresenta tendência de diminuição acentuada até 2008 .

Como resultado do comportamento do tamanho médio dos domicílios e do tamanho da população, tem-se no gráfico 6 o fluxo de formação de domicílios que será adicionado ao estoque brasileiro anualmente. 


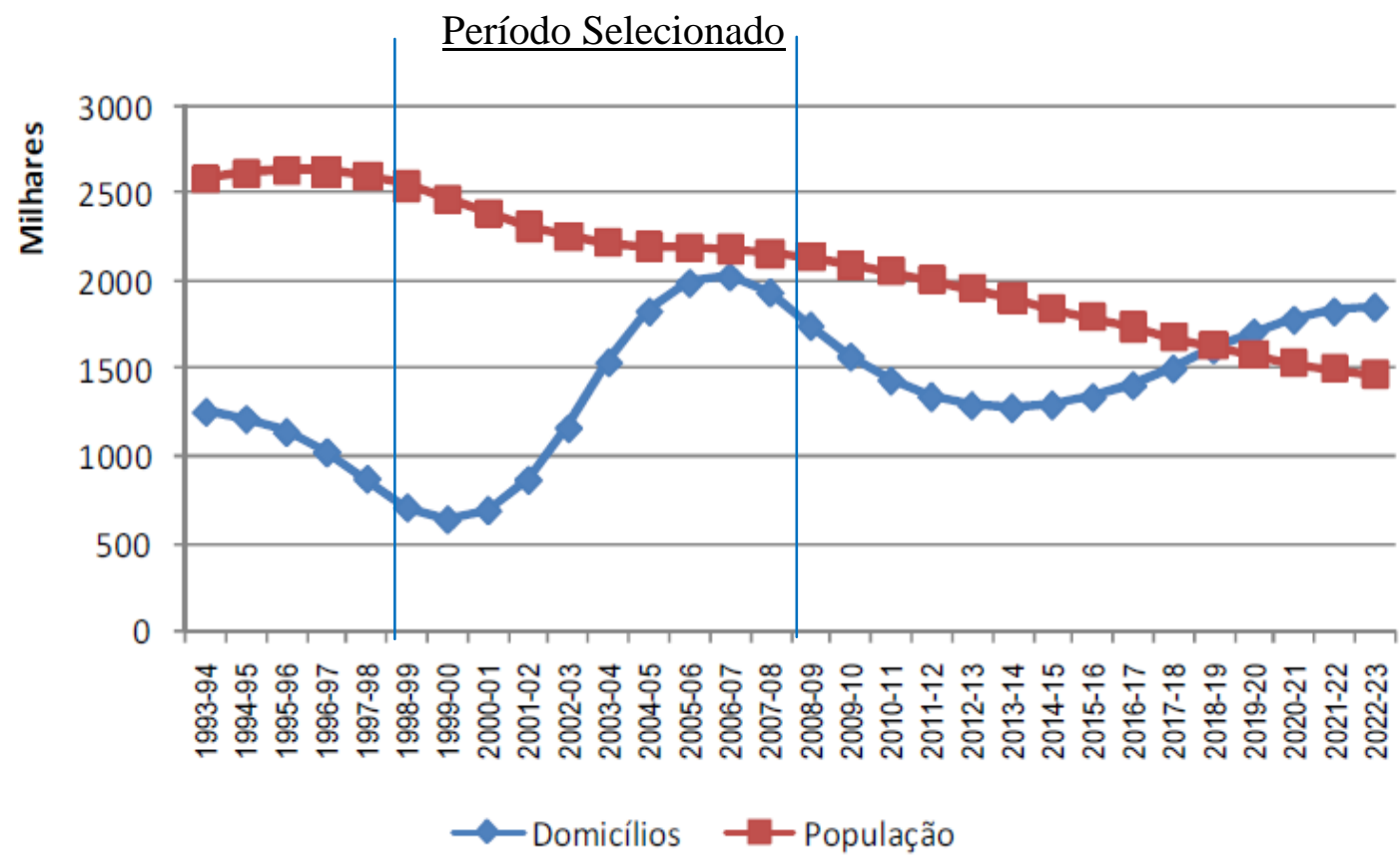

Gráfico 6 - Formação de domicílios x incremento da população do Brasil

Fonte: PNAD (IBGE, 1982 a 2004). Projeção Populacional (CEDEPLAR, 2007). Projeção Taxas de Chefia de Domicílios (CEDEPLAR, 2007)

De acordo com o exposto no gráfico acima é possível notar o incremento no número de domicílios no período selecionado de aproximadamente 600 mil anuais para 2 milhões. No entanto o crescimento populacional passou de 2,5 milhões para aproximadamente 2,1 milhões ao final de 2008.

Analisando a mesma curva de formação de domicílio $\mathrm{x}$ incremento da população na região sudeste, pode-se notar que a partir de 2003 o incremento no número de domicílios supera o da população, mostrando claramente o efeito mais intenso das mudanças na dinâmica demográfica desta região em relação ao Brasil. Conforme apresentado no gráfico 6, o incremento anual no número de domicílios passou de aproximadamente 300 mil em 1998 para 650 mil ao final de 2008. No mesmo período, o incremento populacional passou de 1 milhão para o mesmo nível da formação de domicílios de 650 mil. 


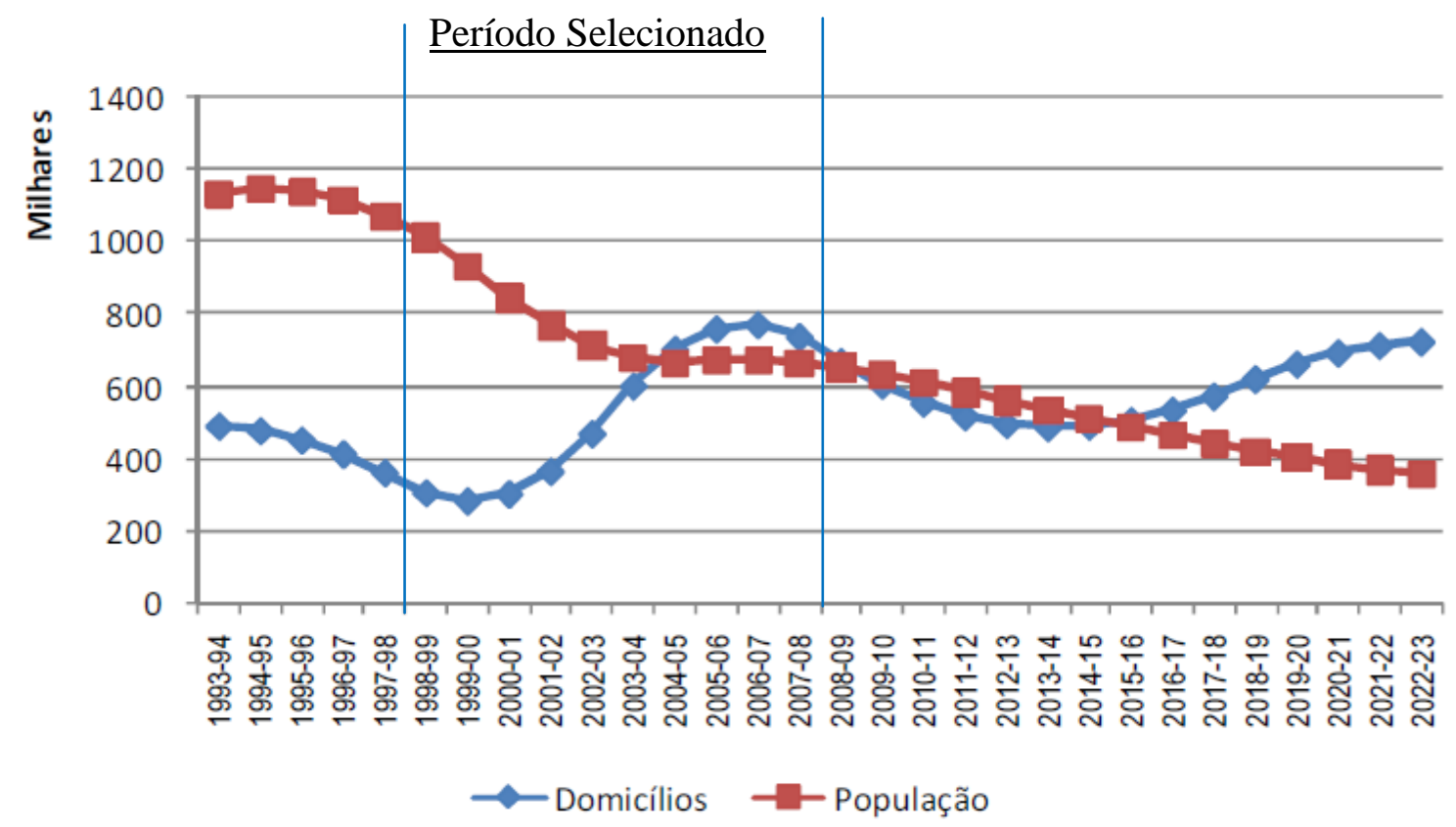

Gráfico 7 - Formação de domicílios x incremento da população no Sudeste do Brasil Fonte: PNAD (IBGE, 1982 a 2004). Projeção Populacional (CEDEPLAR, 2007). Projeção Taxas de Chefia de Domicílios (CEDEPLAR, 2007)

O mesmo comportamento é evidenciado na cidade de São Paulo que, conforme apresentado em MEYER(2006), em nove anos da década de 90 (1991 a 2000) foram formados 446.024 domicílios particulares permanentes no Município de São Paulo o que representa uma média anual de aproximadamente 50 mil. No mesmo período a população apresentou um incremento de $8,2 \%$ enquanto os domicílios cresceram $17,6 \%$, evidenciando mais uma vez mudanças na estrutura familiar. 
4.2.2. A formação de domicílios adequados no período selecionado

Segregando a curva da formação de domicílios adequados ${ }^{12}$ no período selecionado para análise nesta dissertação, no Gráfico 8, tem-se que o Brasil terminou 2008 com aproximadamente 2 milhões de domicílios formados, dos quais 300 mil estão concentrados no Estado de São Paulo. A Região Metropolitana de São Paulo, por sua vez, representa 150 mil domicílios e a cidade de São Paulo 60 mil domicílios.

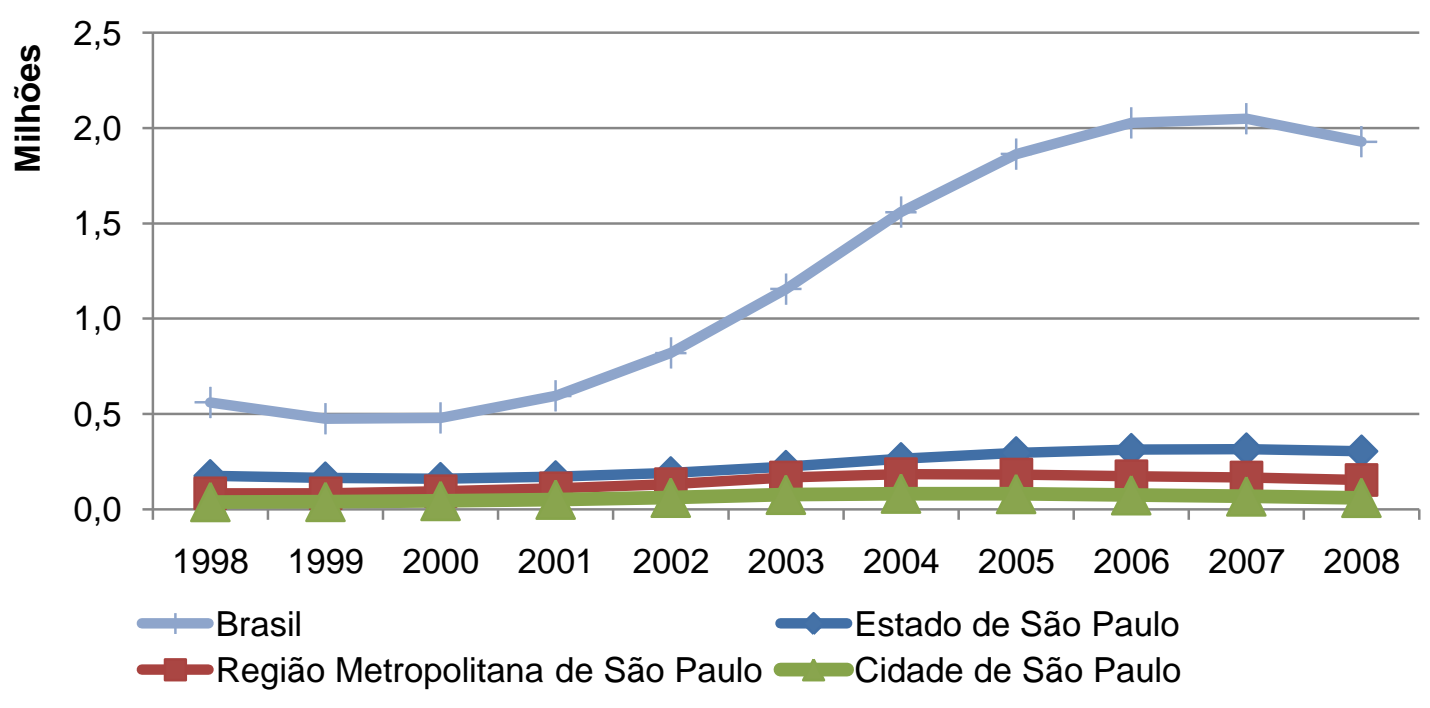

Gráfico 8 - Formação de domicílios adequados: Brasil x São Paulo

Fonte: PNAD (IBGE, 1982 a 2004). Projeção Populacional (CEDEPLAR, 2007). Projeção Taxas de Chefia de Domicílios (CEDEPLAR, 2007) com adaptações do autor

No Gráfico 9 é possível notar a evolução da formação do número de domicílios entre 1998 e 2008, e a concentração de aproximadamente 50\% do incremento de domicílios do Estado de São Paulo na Região Metropolitana. A cidade de São Paulo, por sua vez, concentra aproximadamente $1 / 3$ do incremento de domicílios da Região Metropolitana.

\footnotetext{
${ }^{12}$ A formação de domicílios adequados reflete o crescimento da parcela do estoque de unidades habitacionais segundo o critério apresentado no item 4.1.2.
} 


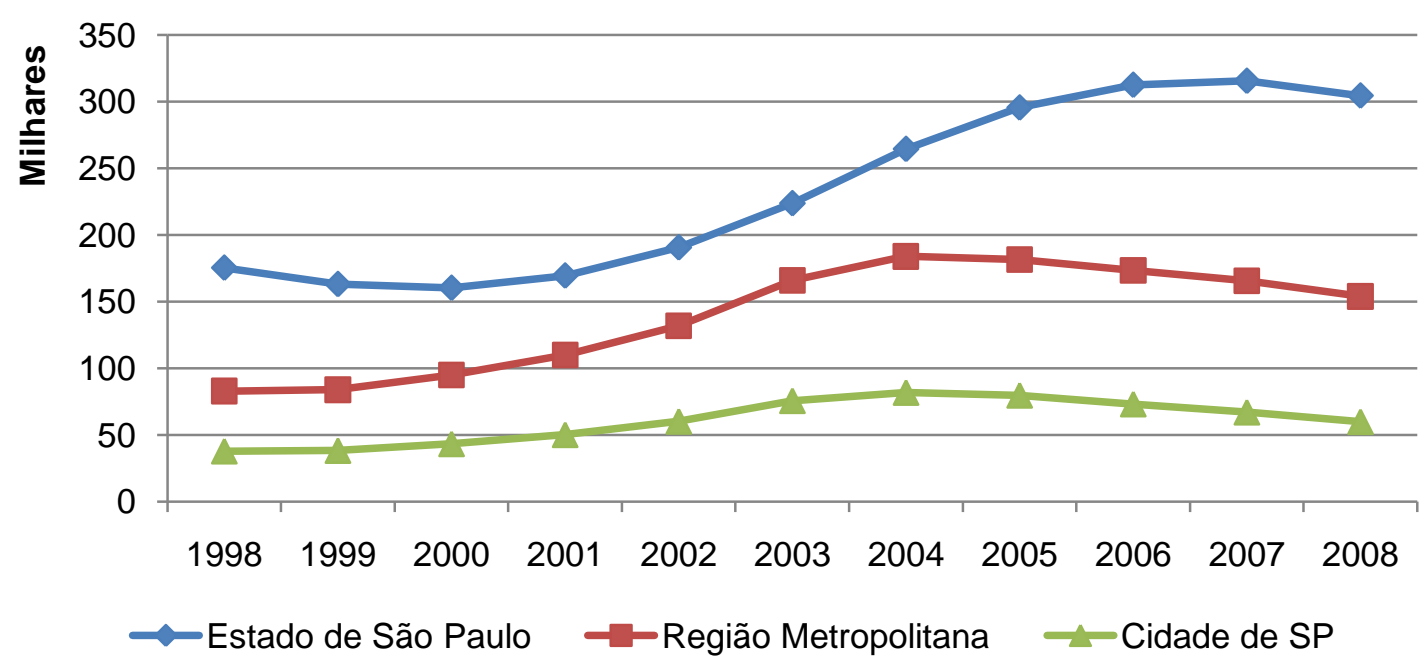

Gráfico 9 - Formação de domicílios adequados: Estado de São Paulo x RMSP e Cidade de SP

Fonte: PNAD (IBGE, 1982 a 2004). Projeção Populacional (CEDEPLAR, 2007). Projeção Taxas de Chefia de Domicílios (CEDEPLAR, 2007) com adaptações do autor

4.2.3. A formação de domicílios comparada à produção de unidades

Conforme mencionado no item 3.3, vale ressaltar que existe um descompasso de 18 a 42 meses entre a oferta do empreendimento e sua entrega ao mercado. No entanto, seguindo o objetivo do trabalho e os conceitos apresentados, o comportamento da PRODUÇÃo HABITACIONAL PRIVAdA será inferido a partir das novas unidades habitacionais ofertadas ao mercado no período.

No gráfico a seguir é apresentado o comportamento da FORMAÇÃo DE DOMICÍlIOS e a Produção Habitacional Privada na cidade de São Paulo. 


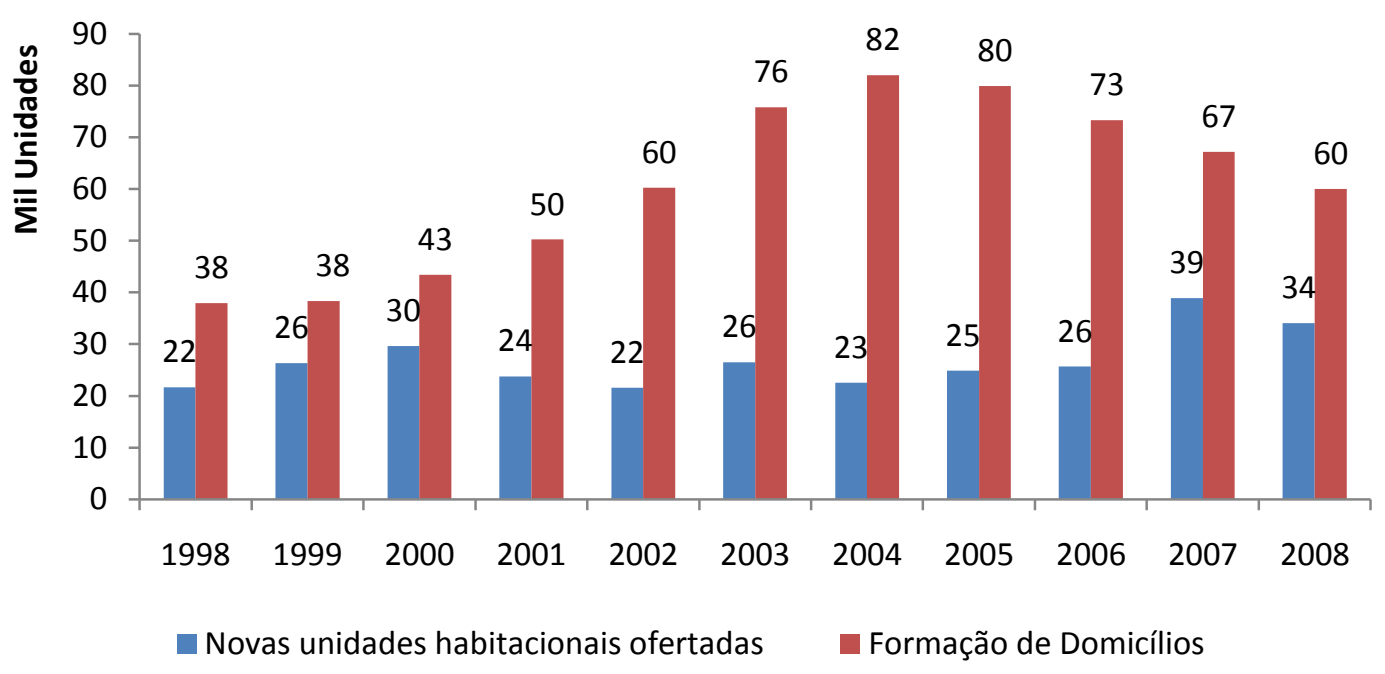

Gráfico 10 - Novas unidades habitacionais ofertadas x formação de domicílios adequados na cidade de São Paulo

Nota-se a partir do gráfico anterior que a PRODUÇão HABITACIONAL PRIVADA não superou a FormAÇÃo De DOMIĆ́lIOS no período. Nos anos de 1998 e de 2008 a produção de unidades atingiu o máximo de participação relativa à formação de domicílios, atingindo $57 \%$ do total.

Seguindo o conceito exposto no capítulo 2, a produção de unidades deveria acompanhar a formação de domicílios diferentemente do observado no período selecionado. Dessa forma, uma vez que efetivamente foram formados novos domicílios e a produção de unidades no mercado de empreendimentos imobiliários habitacionais não atingiu o mesmo patamar de incremento, é possível se levantar as hipóteses de que (i) a diferença foi absorvida pela modalidade de PRODUÇÃo PRÓPRIA (ii) houve uma ocupação nos imóveis vagos.

Não existe indicativos que o movimento de ocupação dos imóveis vagos foi intenso no período selecionado, o que reforça a hipótese que a maior parcela não atendida foi satisfeita pela Produção PRóPRIA, no entanto, sem dados ou estudos que a comprovem. No entanto, pode-se afirmar que os empreendedores não ofertaram unidades habitacionais na mesma proporção que a formação de domicílios, deixando espaços para outras modalidades de produção. 
Apesar dos valores absolutos não serem equivalentes, o movimento da PRODUÇÃO Habitacional Privada deveria acompanhar a Formação De Domicílios. Para observar esse comportamento relativo, o gráfico seguinte apresenta a formação de domicílios em número índice considerando 1998=100.

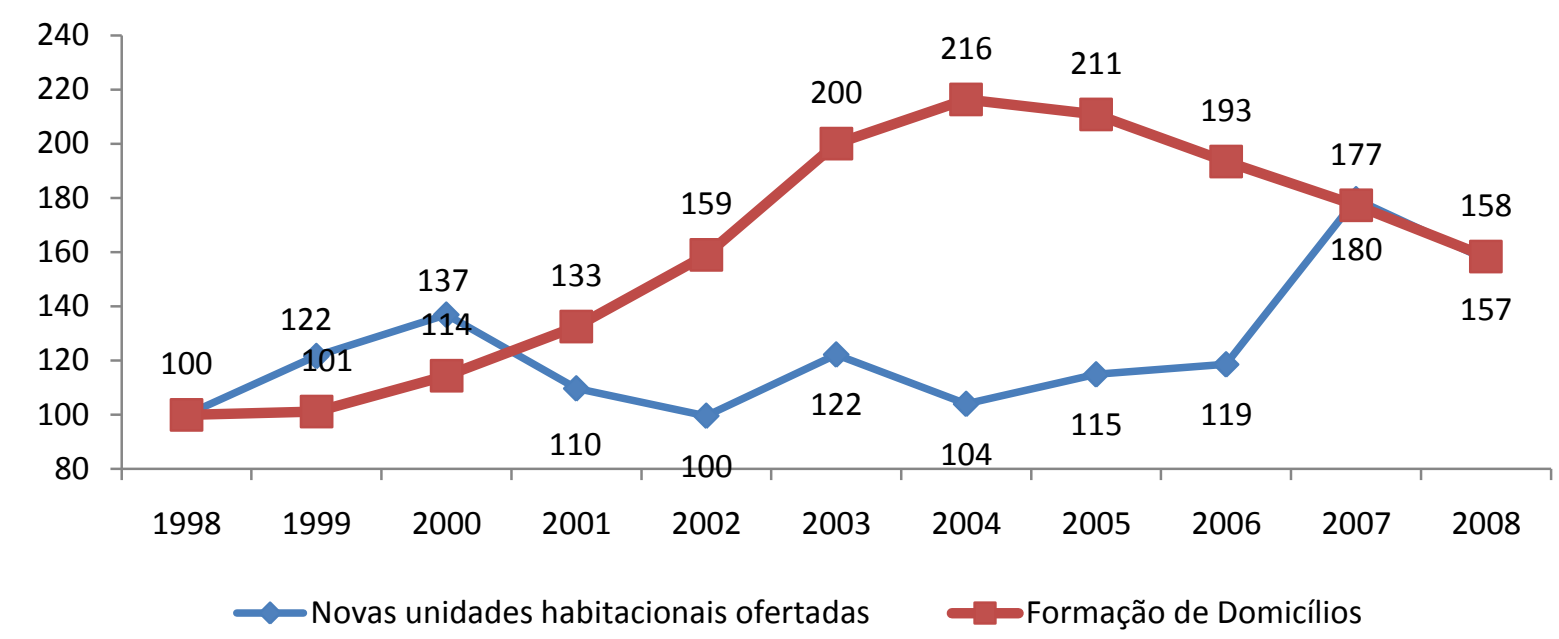

Gráfico 11 - Novas unidades habitacionais ofertadas x formação de domicílios adequados na cidade de São Paulo

É possível notar que até o ano 2000 a produção de unidades acompanha a formação de domicílios. No entanto, a partir de 2001 há o descolamento da PrODUÇÃo Habitacional Privada e da Formação De Domicílios. Somente após 6 anos, em 2007, o nível de produção de unidades se recupera e alcança o incremento de domicílios na cidade de São Paulo.

Como esperado, pode-se observar que a Produção Habitacional Privada não reproduziu o mesmo comportamento descrito na bibliografia na cidade de São Paulo conforme sintetizado no esquema abaixo. O cálculo do coeficiente de correlação de Person (r) resultou no valor de 0,04 , o que representa uma correlação fraca positiva. 


\begin{tabular}{c|c|cc}
\multirow{2}{*}{$\begin{array}{c}\text { FormaÇão de } \\
\text { Domicílios }\end{array}$} & \multicolumn{3}{|c}{ Produção Habitacional Privada } \\
\cline { 2 - 4 } & Premissa & Observado & r \\
\hline$\uparrow$ & $\uparrow$ & $\leftrightarrow$ & 0,04
\end{tabular}

Seguindo o objetivo do trabalho, será explorado nos próximos capítulos o comportamento das demais variáveis condicionantes da PRODUÇÃo Habitacional PRIVADA buscando os agentes explicativos do descolamento apresentado no último gráfico.

\section{A OFERTA DE RECURSOS PARA O SETOR HABITACIONAL}

A Oferta De Recursos pode ser dividida entre (i) Financiamento Habitacional e (ii) Financiamento À Produção. Conforme mencionado anteriormente, o FinANCIAMENTO HABITACIONAL é voltado ao financiamento aos compradores e é fundamental para viabilizar o financiamento de longo prazo, transferindo as carteiras de recebíveis originadas pelos empreendedores para as instituições financeiras. Por sua vez, o FinANCIAMENTO À ProduÇão tem a finalidade de apoiar a necessidade de capital dos empreendedores durante o ciclo de produção.

Historicamente o Brasil contou com duas fontes oficiais e específicas de recursos para o setor habitacional, (i) os depósitos de poupança do Sistema Brasileiro de Poupança e Empréstimo (SBPE) e (ii) os depósitos do Fundo de Garantia do Tempo de Serviço (FGTS), sendo ambas as fontes fortemente subsidiadas e reguladas por meio do Sistema Financeiro de Habitação (SFH). 
Mais recentemente, em 1997, foi criado também o Sistema Financeiro Imobiliário (SFI) que teve por objetivo criar as condições necessárias para viabilizar o acesso aos recursos do mercado de capitais em complemento aos recursos subsidiados e regulados pelo SFH.

Pode-se citar como ambiente de captação de investimentos no mercado de capitais específicos para o mercado imobiliário os Fundos de Investimento Imobiliário (FII) e os Fundo de Investimento em Participações (FIP). Como instrumento ou veículo de investimento é possível citar os Certificados de Recebíveis Imobiliários (CRIs) e as quotas dos fundos citados.

Além desses instrumentos específicos, existem ainda aqueles derivados do mercado de capitais e utilizados largamente por todos os setores da economia para captar recursos, como por exemplo, a emissão de debêntures, notas promissórias, além das emissões primárias de ações.

Inicialmente serão apresentadas nos itens 5.1, 5.2 e 5.3 as fontes oficiais e específicas de recursos para o setor. $\mathrm{Na}$ seqüência serão apresentadas as demais fontes de recursos disponíveis no período selecionado e seu comportamento.

\subsection{Breve histórico da criação do SFH}

O SFH foi criado em 1964 por meio da Lei $\mathrm{n}^{\circ} 4.380$ (21/08/64) tornando-se um marco fundamental na história da intervenção governamental no setor habitacional. Antes do surgimento desta lei, o comportamento do setor de financiamento habitacional apresentava distorções devido às altas taxas de inflação na economia enquanto existia um limite máximo de $12 \%$ ao ano mais a correção monetária para as taxas de juros nominais dos financiamentos. Este cenário de taxas de juros reais negativas inviabilizava a operação dos agentes financeiros no mercado de financiamento imobiliário. Segundo VASCONCELOS (1996), somente com a instituição da correção monetária (Lei $n^{\circ}$ 4.357, de 17/07/64), foi possível 
implementar o Sistema Brasileiro de Poupança e Empréstimo (SBPE) que seria capaz de atrair recursos para suportar o SFH.

\subsubsection{O Banco Nacional da Habitação}

Segundo KOHLER (2005), inicialmente, o sistema era composto pelo Banco Nacional de Habitação (BNH), pelas Companhias de Habitação (COHAB's), pelas Cooperativas Habitacionais (COOPHAB's), pelas Sociedades de Crédito Imobiliário (SCI's) e pelas Caixas Econômicas Federal (CEF) e Estaduais (CEE's). Em 1966, foram criadas as Associações de Poupança e Empréstimo (APE’s). Essas instituições se destinavam a atender mercados distintos e contavam com diferentes fontes de recursos.

O BNH tinha uma função social por meio das COHABs e COOPHABs destinando seus financiamentos às camadas mais pobres da população (até seis salários mínimos) e contava inicialmente com recursos a fundo perdido sob a forma de $1 \%$ da folha de pagamento de todos os empregados sujeitos ao regime da CLT. Estes recursos se mostraram insuficientes e levou o governo, em 1966, a criar o FGTS (Lei no $5.107 / 66)^{13}$. A gestão FGTS era de responsabilidade do BNH, tornando-se a sua principal fonte de recursos e instrumento de implantação da sua programação dentro do Sistema. No entanto, ainda segundo KOHLER (2005), tais recursos seriam obrigatoriamente destinados a operações com garantias reais, com correção monetária e com rentabilidade superior ao custo do dinheiro depositado, inclusive juros.

Outra responsabilidade do $\mathrm{BNH}$ era ser o provedor de última instância do $\mathrm{SFH}$, garantindo a liquidez e a solvência do sistema. Dessa forma, o BNH era o gestor do Fundo de Garantia de Depósitos e Letras Imobiliárias (FGDLI) e do Fundo de Assistência de Liquidez (FAL). Esses fundos foram concebidos com o propósito de cobrir riscos de atividades e operações do SFH. Ambos contavam com recursos

\footnotetext{
${ }^{13}$ O FGTS é um fundo compulsório constituído pelo conjunto de contas vinculadas e individuais, abertas pelos empregadores em nome de seus empregados, a partir do recolhimento de $8 \%$ sobre a folha de salários e da aplicação de juros e correção monetária.
} 
advindos de contribuições compulsórias correspondentes a um determinado percentual do saldo de recursos captados junto ao público pelas instituições financeiras. O objetivo do FGDLI era garantir a integridade das poupanças populares aplicadas em letras imobiliárias e nas cadernetas de poupança, enquanto o do FAL era evitar a iliquidez das entidades que compunham o SBPE.

Por sua vez, o SBPE era integrado por instituições públicas e privadas (SCIs, APEs e Caixas Econômicas) que captavam recursos do público por meio de instrumentos como os depósitos voluntários de poupança e as letras imobiliárias (LI), e financiavam os mercados de classes média e alta, podendo também aplicar recursos do FGTS.

Ambas as fontes de recursos têm forte carga de subsídio. No caso do SBPE, existe a isenção do imposto de renda sobre os rendimentos da caderneta de poupança ${ }^{14}$ e, no FGTS $^{15}$, os subsídios são extraídos dos depositantes compulsórios, que não têm como sacar ou utilizar as rentabilidades de suas aplicações. Além disso, as rentabilidades são inferiores a variação da inflação. Por exemplo, entre janeiro de 2000 e dezembro de 2004, para uma variação de 51,01\% no IPCA, os depósitos do FGTS tiveram uma rentabilidade total, entre atualização e juros, de 32,89\%, o que equivale a uma perda real anual de 2,5\%.

De maneira geral, pode-se dizer que o SFH era o responsável por fornecer recursos para todo o ciclo do setor habitacional, desde o FINANCIAMENTO À PRODUÇÃo até o FinANCIAMENTO HABITACIONAL. Este sistema é operado a partir de duas fontes de recursos, cada um direcionado para diferentes estratos da população. Enquanto os recursos do FGTS são voltados à população com renda insuficiente para recorrer a financiamentos e, portanto, com a necessidade de subsídio para adquirir um imóvel, os recursos do SBPE são voltados para a população com renda adequada para contrair o FINANCIAMENTO HABITACIONAL.

\footnotetext{
${ }^{14}$ A caderneta de poupança oferece uma rentabilidade anual de $6 \%$ mais correção monetária atrelada a Taxa Referencial (TR)

${ }^{15}$ A rentabilidade dos depósitos do FGTS são de 3\% de juros ao ano mais correção monetária pela TR
} 
Conforme citado em SANTOS (1999), ainda em 1967, foi criado o Fundo de Compensação das Variações Salariais (FCVS) que seria responsável por cobrir as distorções geradas pelo descasamento entre a evolução dos saldos devedores dos financiamentos imobiliários e a evolução das prestações dos financiamentos segundo o Plano de Equivalência Salarial (PES).

O Plano de Equivalência Salarial estabelecia o reajuste anual das prestações considerando o aumento médio dos salários. Para eliminar o descasamento entre as correções de parcela e saldo devedor iniciou-se a cobrança de uma sobreprestação mensal que seria destinada para financiar o FCVS, que no final do contrato quitaria o saldo devedor remanescente de cada mutuário.

\subsubsection{A extinção do BNH}

É importante ressaltar que o BNH desempenhou as funções do órgão central no SFH até 1986. A desestruturação do FCVS teve início em 1983 devido à aceleração da inflação para patamares acima de $100 \%$ ao ano. Neste período foi iniciada uma pressão política que resultou na concessão de um elevado subsídio para os mutuários do sistema em 1985. Buscando diminuir o intervalo de reajuste das prestações foi oferecida uma redução aos mutuários na correção monetária plena de $246,3 \%$ do saldo devedor para $112 \%$ daqueles que optassem pela semestralidade das correções. Os que desejassem manter as indexações anuais teriam o reajuste total. Dessa forma, o subsídio concedido contribuiu para diminuir as taxas de inadimplência e aumentou a liquidez de curto prazo do sistema. No entanto, esse subsídio aumentou o descasamento entre a evolução do passivo junto aos poupadores do SBPE e ao FGTS e o ativo, representado pelas prestações dos mutuários do $\mathrm{SFH}$, contribuindo assim de maneira decisiva para a insolvência do FCVS.

O equilíbrio atuarial do sistema sofreu outra perturbação com o lançamento do Plano Cruzado em 1986. Nesta ocasião, as prestações dos mutuários deveriam ser reajustadas pela média dos reajustes dos doze meses imediatamente anteriores, 
permanecendo fixas nos doze meses seguintes enquanto a correção monetária continuava a reajustar o passivo do sistema.

Em meio a este cenário, em 1986 o BNH foi extinto e suas responsabilidades foram distribuídas para: (i) Ministério do Desenvolvimento Urbano e Meio Ambiente (MDU), que seria responsável pelas políticas urbanas e de desenvolvimento urbano; (ii) Conselho Monetário Nacional (CMN), que teria a função de orientar, disciplinar e controlar o SFH; (iii) Banco Central do Brasil (BACEN), que concentraria as atividades de fiscalização das instituições financeiras que integram o SFH e (iv) CEF que seria responsável por administrar o passivo, ativo, pessoal e bens móveis e imóveis do BNH.

Os recursos do SBPE continuaram sendo regulados pelas regras do SFH e operados pelas instituições públicas e privadas que captavam recursos dos depósitos de poupança. Desde então, o sistema continua sendo utilizado como a principal fonte de recursos para o setor, apoiado principalmente nos subsídios do SBPE e do FGTS.

5.2. Participação do SFH no financiamento do setor habitacional no período selecionado

O número de financiamentos dentro do SBPE e do FGTS não tem acompanhado o crescimento populacional brasileiro. De acordo com os dados divulgados pelo BACEN, no auge do número de unidades financiadas, observa-se que entre 1980 e 1982, o FGTS e o SBPE financiaram anualmente 540 mil unidades, enquanto a população total brasileira era de aproximadamente 125 milhões segundo dados do IBGE. Na década de 1990, a média de financiamentos anuais concedidos foi de 178 mil, para uma população em 1995 estimada em 160 milhões de pessoas (IBGE).

Entre 1991 e 2000, os domicílios permanentes no País passaram de 34,1 milhões para 44,8 milhões, uma média de quase 1,2 milhão de novas residências por ano. No 
período, em média, o FGTS forneceu 130 mil financiamentos anuais e o SBPE 48 mil financiamentos por ano.

5.2.1. A participação do crédito imobiliário no sistema financeiro brasileiro

Analisando o saldo total das operações de crédito no SFH, conforme exposto no gráfico a diante, nota-se que no final de 2008 sua participação era de 2,1\% do Produto Interno Bruto (PIB), enquanto o total das operações financeiras era de $40,4 \%$. Isto representa apenas 5\% das operações financeiras nacionais. No início do período em análise (janeiro de 1998) esta participação era de aproximadamente 19\%. Esta redução é explicada pelo incremento nas operações financeiras totais do país, o que evidencia uma melhora dos fundamentos econômicos nacionais, e uma redução das operações no SFH.

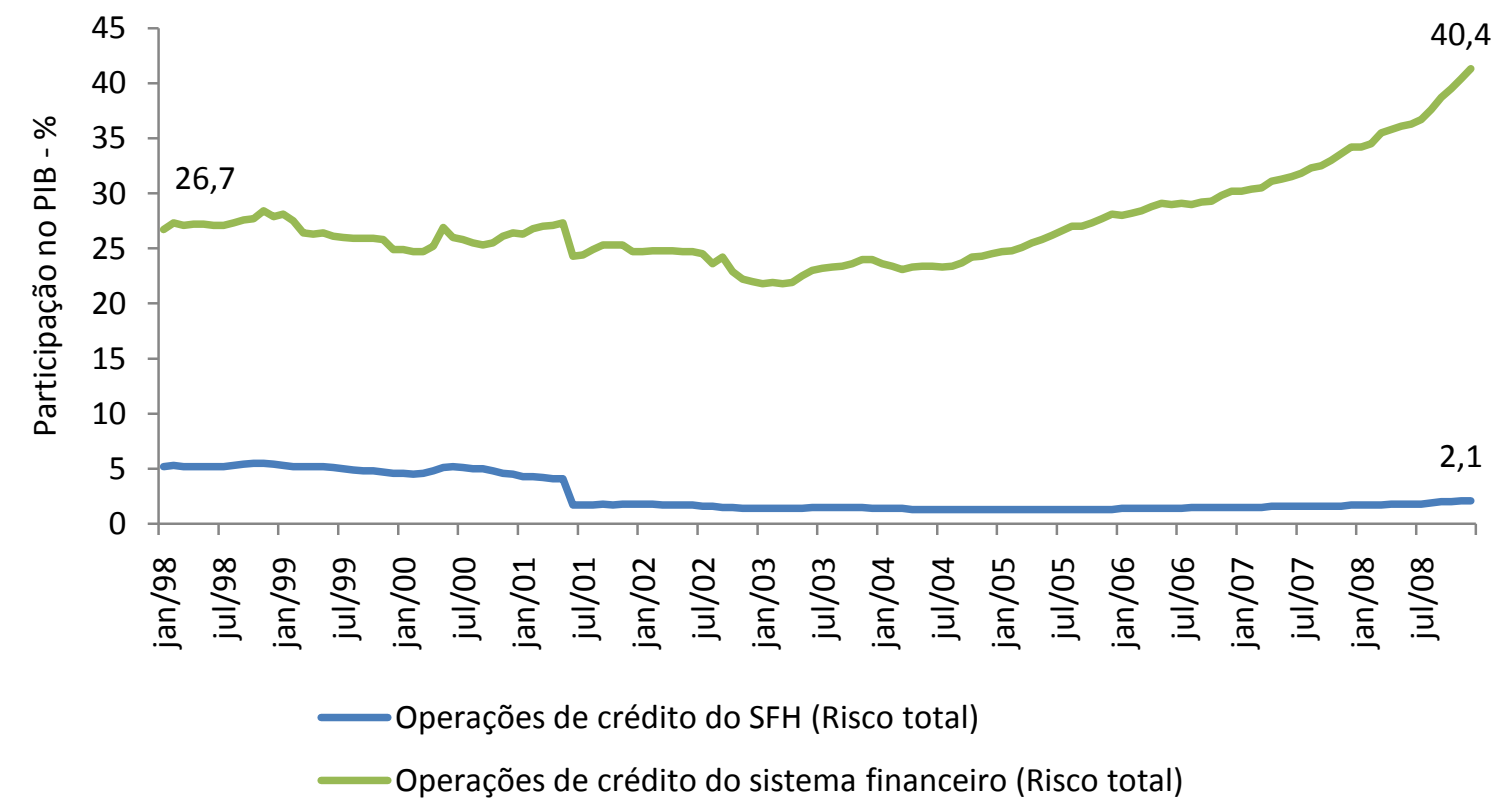

Gráfico 12 - Participação do estoque total das operações de crédito do SFH e do sistema financeiro no PIB Fonte: Bacen 
A brusca queda no número de operações de crédito no SFH é explicada pela criação em junho de 2001 da Empresa Gestora de Ativos (EMGEA). A EMGEA foi criada pela medida provisória $\mathrm{n}^{\circ}$ 2.196, de 28.6.2001 - CRIAÇÃO DO PROGRAMA DE FORTALECIMENTO DAS INSTITUIÇÕES FINANCEIRAS FEDERAIS, que buscou adequar à situação patrimonial de quatro bancos públicos federais - Banco do Brasil (BB), CEF, Banco do Nordeste (BNB) e Banco da Amazônia (BASA). Como resultado houve a diminuição de $60 \%$ do saldo das operações de crédito direcionadas ao setor habitacional, repassando R \$ 30,2 bilhões para a EMGEA, melhorando assim a qualidade da carteira e diminuindo o risco de crédito destas instituições.

Analisando apenas a participação das operações de crédito do SFH no PIB, nota-se no gráfico a seguir que, após cair de 1,7\% em julho de 2001 para 1,3\% em julho de 2005, ela cresce aproximadamente $62 \%$ alcançando $2,1 \%$ no final de 2008 . No mesmo período as operações totais do sistema financeiro cresceram 55\%, o que comprova que o setor de financiamento habitacional acompanhou o movimento da economia.

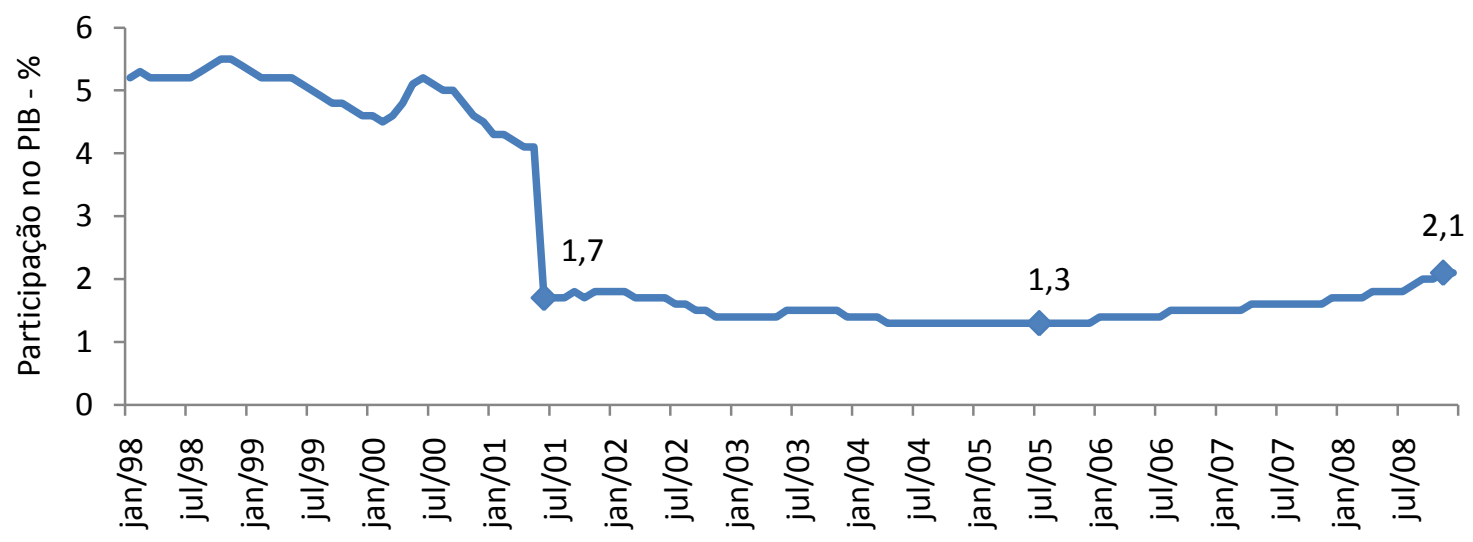

Gráfico 13 - Participação do estoque total das operações de crédito do SFH no PIB Fonte: Bacen

De acordo com os dados do BACEN. o saldo do SBPE passou de aproximadamente R\$ 82 bilhões no início de 1998 para R\$ 215 bilhões no final de 2008, o que representa um aumento de $162 \%$ enquanto a inflação acumulada no período segundo a variação do IPCA foi de $101 \%$. A utilização dos recursos superou historicamente o 
saldo do SBPE. Para fazer frente a esse hiato neste período foram utilizados recursos de repasses, refinanciamentos, fundos e programas sociais da união, além de Letras e Cédulas Hipotecárias emitidas pelas instituições. Mesmo com a utilização destes recursos, somente após 2007 essa conta passou a ser superavitária.

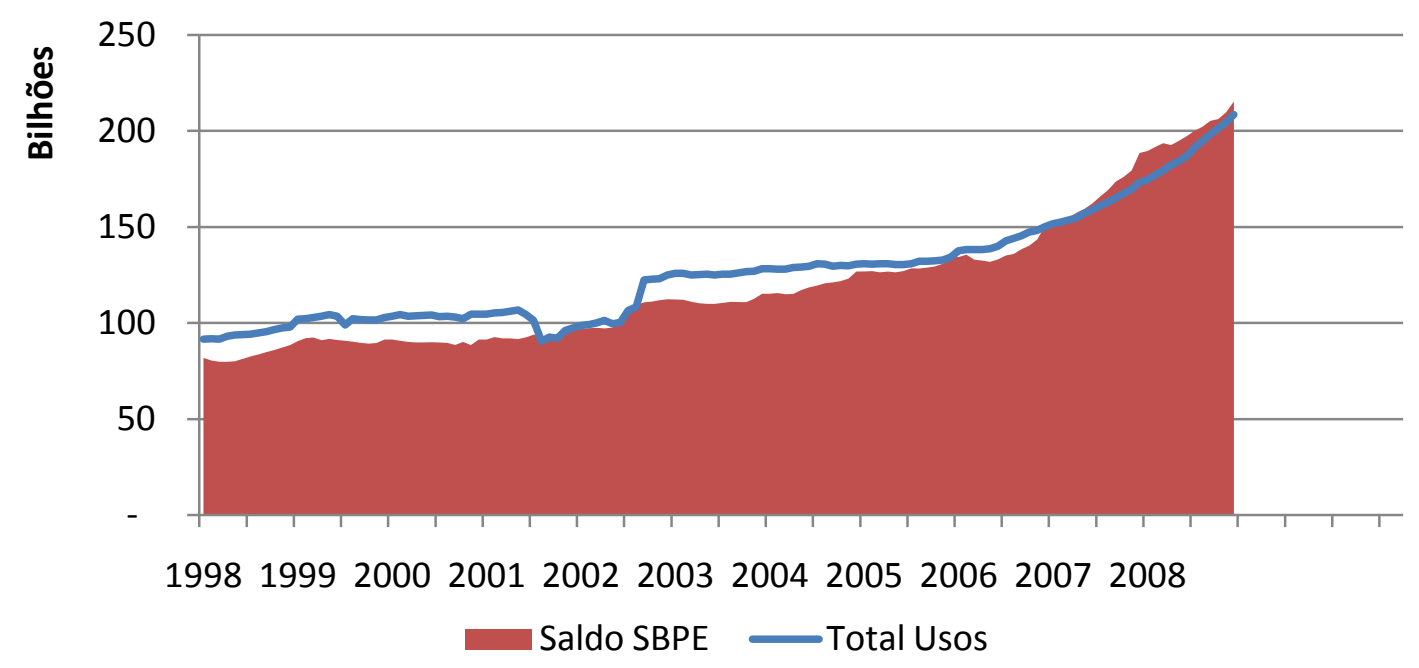

\section{Gráfico 14 - Saldo do SBPE x Usos}

Fonte: Bacen

5.2.2. O direcionamento dos recursos do SBPE

De acordo com as regras do SFH no final de 2008, a utilização dos recursos deve respeitar os limites de $65 \%$ para o financiamento imobiliário, $20 \%$ para o fundo de reserva e $15 \%$ para ser aplicado livremente conforme exposto na próxima figura. Os recursos do financiamento imobiliário são divididos entre aqueles dentro das regras do SFH, respeitando valor máximo e utilização residencial do imóvel, prazos de pagamento, taxas de juros ${ }^{16}$ e constituição de garantia ${ }^{17}$, e aqueles dentro da Carteira Hipotecária, que variam livremente de acordo com as regras determinadas pelas instituições financeiras que estão concedendo o financiamento.

\footnotetext{
${ }^{16}$ As taxas de juros dentro dos limites do SFH estão limitadas a $12 \%$ ao ano mais a correção monetária segundo a Taxa Referencial (TR)

${ }^{17}$ As regras do SFH exigem que o imóvel seja hipotecado à instituição financeira. Mais recentemente foi incorporada a alienação fiduciária como garantia segundo as regras do SFH
} 


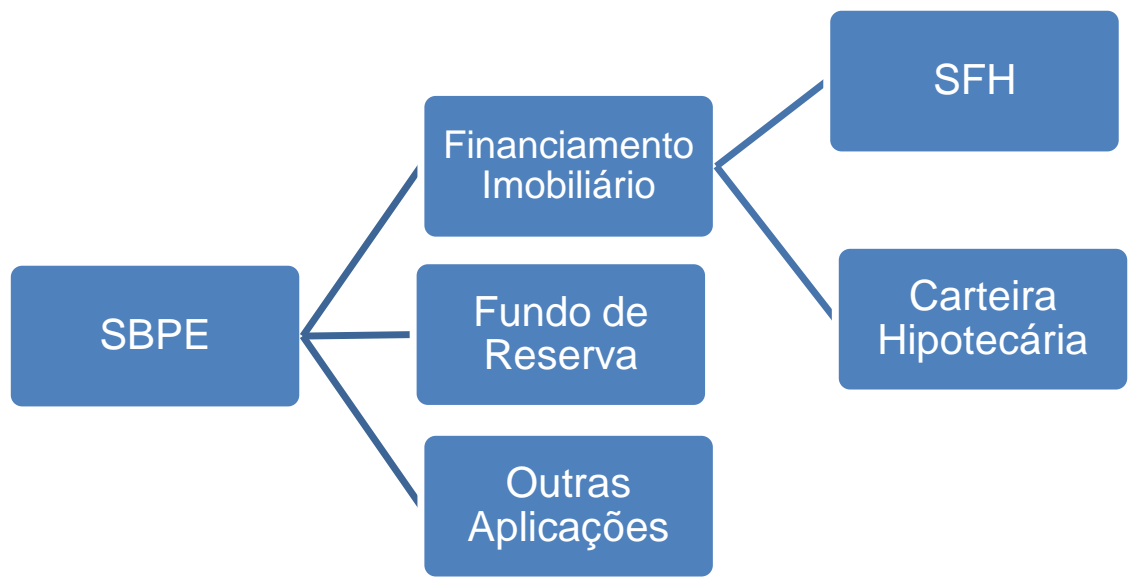

Figura 7- Direcionamento dos recursos do SBPE

Vale ressaltar que também são considerados como aplicação em financiamento imobiliário os créditos das instituições financeiras junto ao FCVS virtual ${ }^{18}$. No gráfico a seguir, são apresentadas as aplicações dos recursos do SBPE de acordo com a regra de direcionamento mencionada.

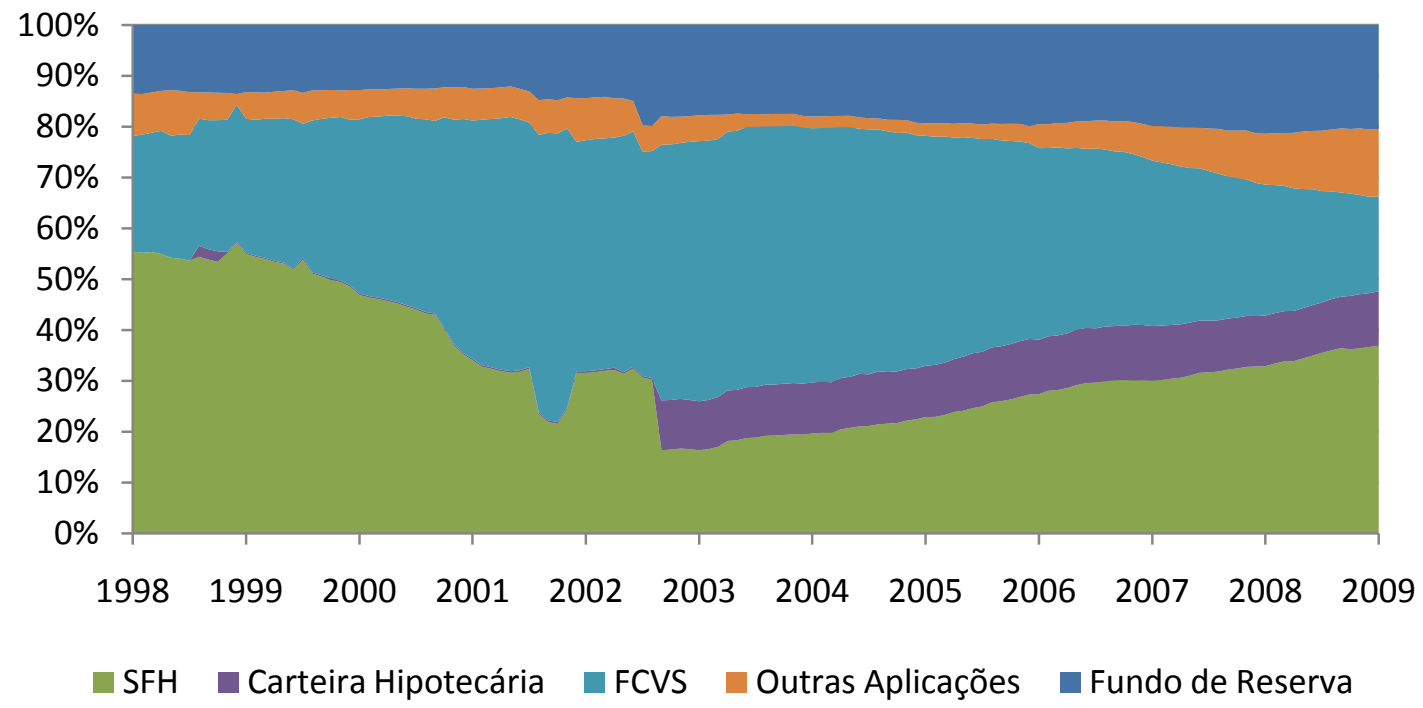

Gráfico 15 - Participação das aplicações dos recursos do SBPE

Fonte: Bacen

\footnotetext{
${ }^{18}$ O FCVS virtual foi originado a partir da utilização dos créditos do fundo mantido pelas instituições que sofreram intervenção nas operações do Programa de Estímulo à Reestruturação e ao Sistema Financeiro Nacional (PROER). Os agentes financeiros que adquiriram bancos falidos que possuíam carteira de crédito imobiliário, puderam contabilizar o correspondente à dívida do Tesouro como cumprimento da exigibilidade dos $65 \%$ da aplicação dos recursos do SBPE em financiamentos habitacional. Essa condição especial deveria durar dois ou três anos no máximo, tempo que seria suficiente para o Tesouro quitar suas dívidas com os bancos, no entanto se estendeu até 2008. O saldo do FCVS virtual representou aproximadamente R $\$ 30$ bilhões.
} 
De acordo com o gráfico apresentado, é possível notar que a carteira de créditos referentes a financiamento imobiliário iniciou o período com aproximadamente $62 \%$ da utilização total dos recursos, chegando ao final de 2008 com $47 \%$ do saldo do SBPE, entre créditos dentro do SFH (36\%) e na carteira hipotecária (11\%).

É importante ressaltar também a grande participação dos créditos do FCVS virtual na aplicação dos recursos, passando de $25 \%$ no início do período selecionado para $58 \%$ em 2003 e, finalmente, sua redução para $18 \%$ no final do período, evidenciando claramente o racionamento dos recursos disponíveis para a utilização no mercado habitacional.

Dessa forma, enquanto o saldo total do SBPE cresceu 162\%, o saldo direcionado para o financiamento imobiliário saltou aproximadamente $100 \%$, de $\mathrm{R} \$ 50$ bilhões para $\mathrm{R} \$ 100$ bilhões, considerando os mesmos 91\% de inflação acumulada no período. Essa redução da participação dos créditos do FCVS na aplicação do saldo do SBPE só foi possível com a atuação estatal na recompra gradual dos créditos iniciada em 2002 e concluída em 2008, liberando assim mais recursos para o setor.

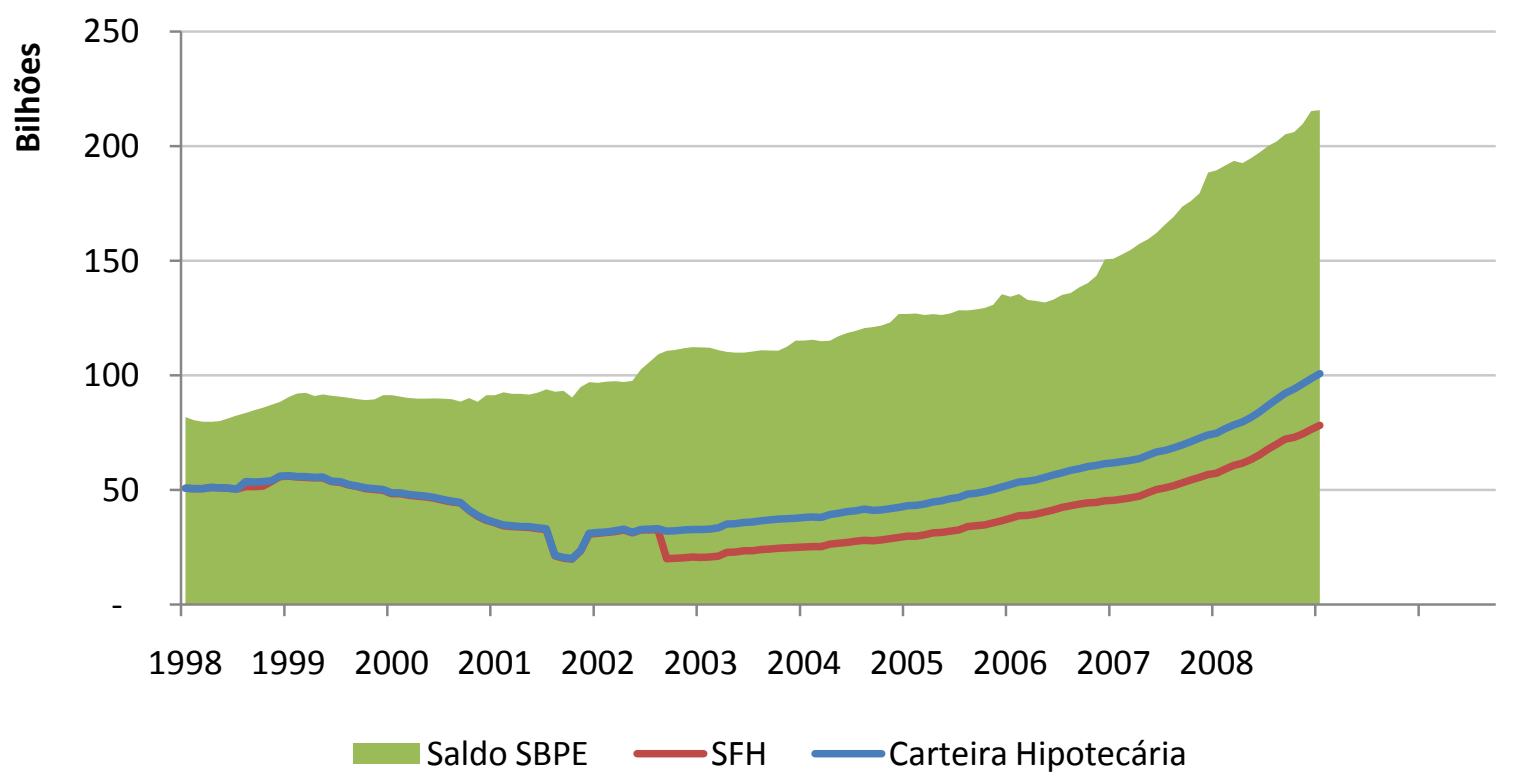

Gráfico 16 - Saldo SBPE x Aplicações dos recursos em financiamento imobiliário Fonte: Bacen 
5.2.3. A oferta de recursos no SBPE e a produção de unidades no período

Analisando a parcela de $65 \%$ do saldo da poupança que segundo as regras de aplicabilidade devem ser direcionadas para o financiamento habitacional, tem-se que durante o período esta se manteve estável até o final de 2006 quando iniciou uma tendência no crescimento atingindo um nível 40\% superior ao do ano de 1998.

No entanto, os recursos efetivamente direcionados apresentaram uma retração que alcançou aproximadamente $60 \%$ em 2003, quando retomou a tendência de crescimento, terminando 2008 no mesmo patamar que 1998. Esse comportamento pode ser observado no gráfico a diante.

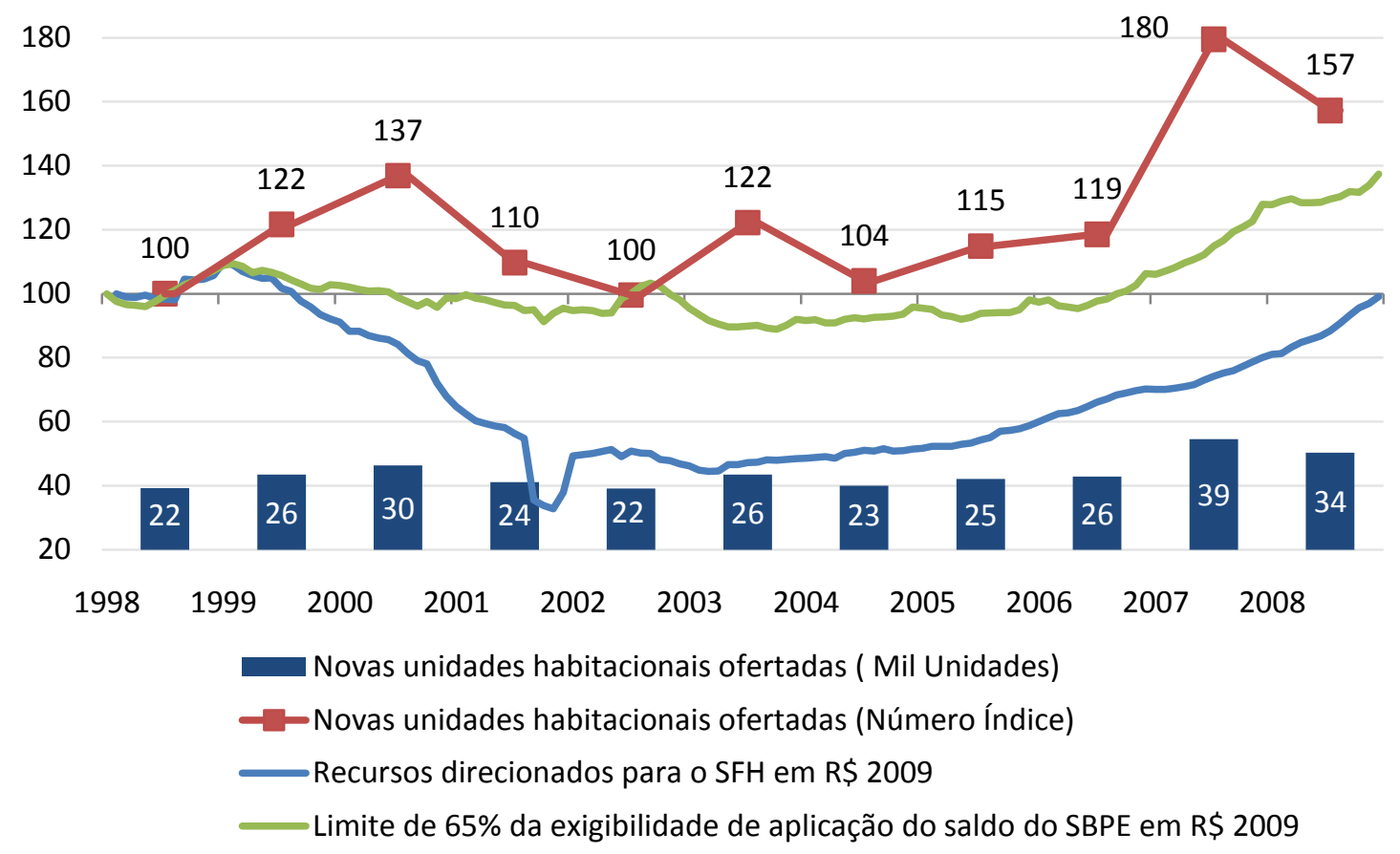

Gráfico 17 - Evolução dos recursos direcionados para o SFH x Limite de 65\% da exigibilidade de aplicação do saldo do SBPE x Novas unidades habitacionais ofertadas

Fonte: Bacen

Ainda conforme o exposto no gráfico anterior, deve-se destacar que, mesmo com a retração do volume direcionado para o SFH, o volume produzido se manteve, indicando que os empreendedores buscaram outros meios de financiamento para continuar a exercer a sua atividade. 


\subsubsection{Originação de financiamentos no SFH}

Como resultado das restrições de recursos disponíveis para o financiamento imobiliário, o volume originado em todo o país com os recursos do SBPE ficou restrito ao patamar de R\$ 2 bilhões até 2003. A partir de 2004 é iniciada uma tendência de aumento na originação de financiamentos imobiliários tanto para a produção quanto para a aquisição unidades habitacionais, atingindo $\mathrm{R} \$ 30$ bilhões ao final de 2008. Esse comportamento pode ser observado no gráfico a seguir.

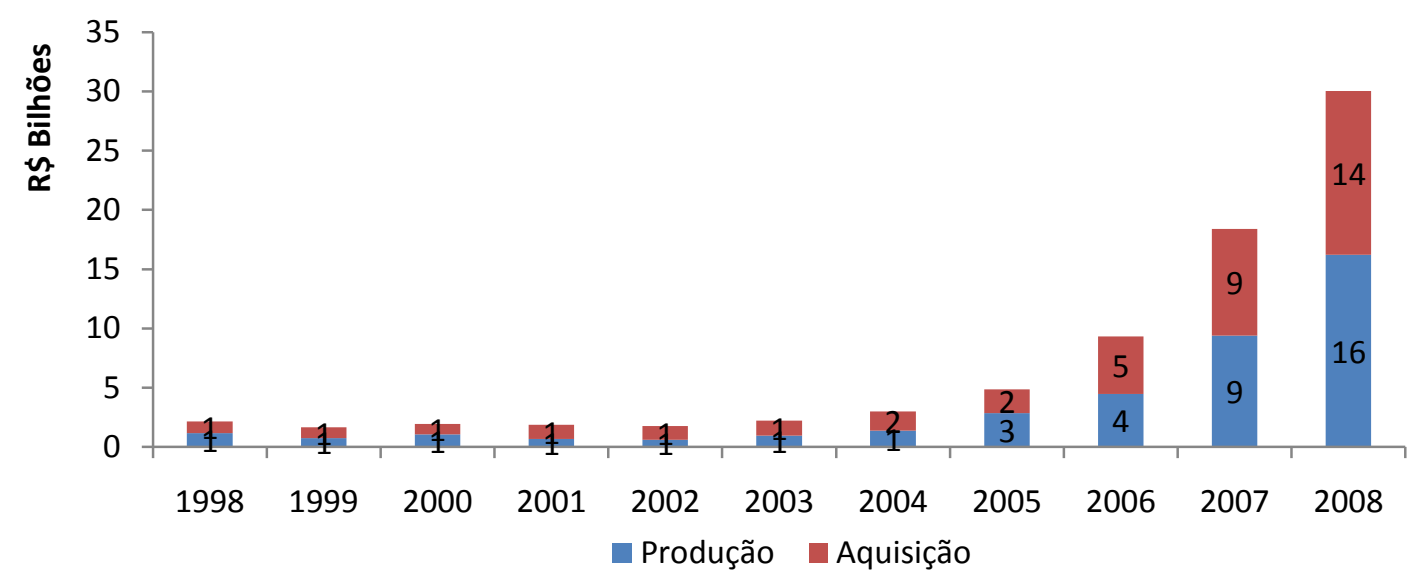

Gráfico 18 - Volume financiado originado no Brasil com recursos do SBPE Fonte: ABECIP

Acompanhando o volume financiado, o número de unidades superou o patamar de 40 mil unidades financiadas anualmente, atingindo 300 mil unidades em 2008. A participação do financiamento para a produção ou aquisição se alternou entre $40 \%$ e $60 \%$ no período selecionado, evidenciando a ligação entre as duas modalidades. No mesmo período, o Valor Médio Financiado (VMF) dos financiamentos passaram de aproximadamente $\mathrm{R} \$ 60$ mil para $\mathrm{R} \$ 100$ mil. No gráfico a seguir é possível notar essa evolução. 


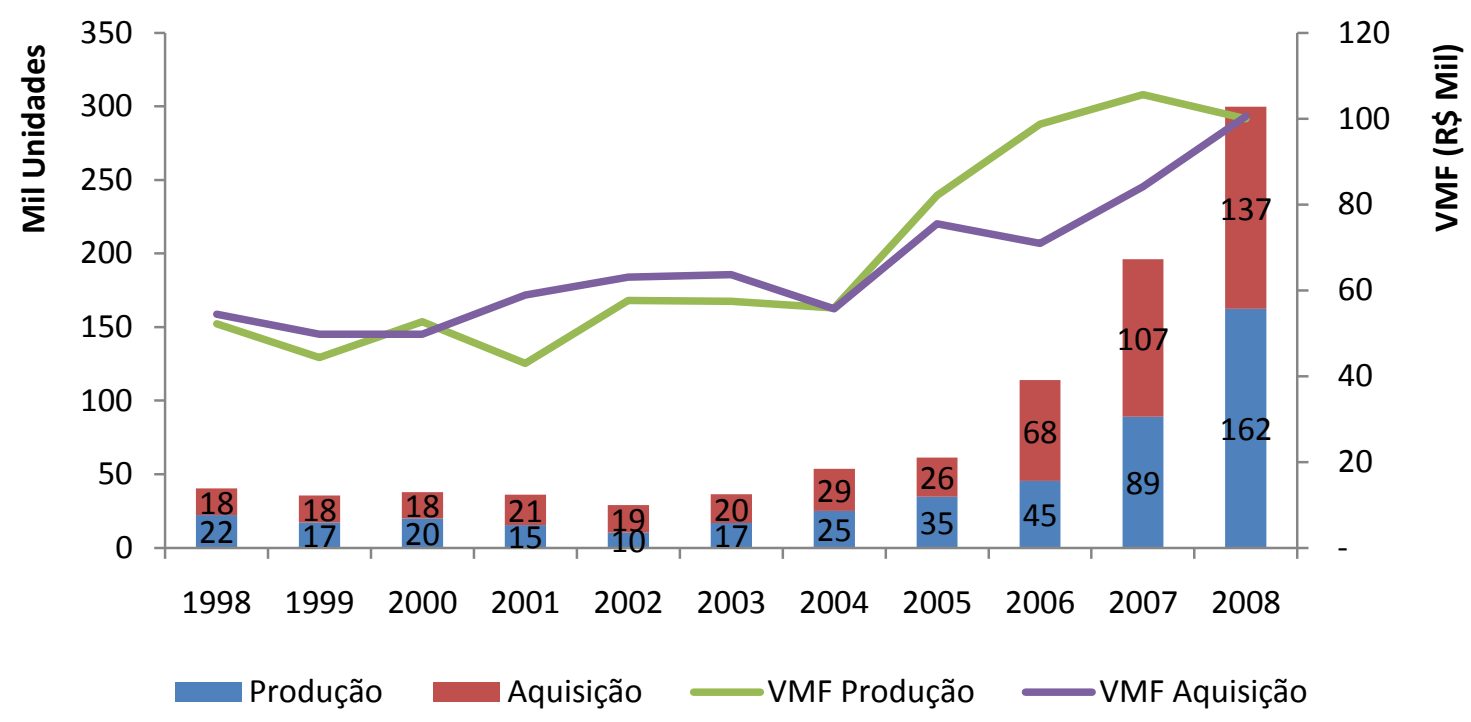

Gráfico 19 - Unidades financiadas originadas no Brasil com recursos do SBPE Fonte: ABECIP

Os limites máximos de valor de imóvel previstos na Lei $\mathrm{n}^{\circ} 4.380$, de 31 de dezembro de 1964, de criação do SFH, previa o limite máximo de financiamento de 300 salários mínimos, o que no final de 2008 representava aproximadamente R 140 mil. Ao longo das décadas subseqüentes esse limite foi sendo alterado, e no final de 2008 o valor máximo do imóvel era de $\mathrm{R}$ \$ 350 mil de acordo com a resolução no 3.280 de 29 de abril de 2005 .

Essa diferença de limites no valor máximo do imóvel a ser financiado dentro do SFH demonstra a adequação do sistema para continuar a abranger a maior parcela dos imóveis do mercado nacional. Mesmo assim, nota-se que o VMF tanto na aquisição quanto na produção não ultrapassa $30 \%$ do valor máximo previsto por lei.

Do volume financiado no Brasil no período, o Estado de São Paulo foi responsável pela aplicação de aproximadamente $50 \%$ dos recursos direcionados. A distribuição entre o volume financiado para a produção e para a aquisição manteve o mesmo comportamento que o nacional. 


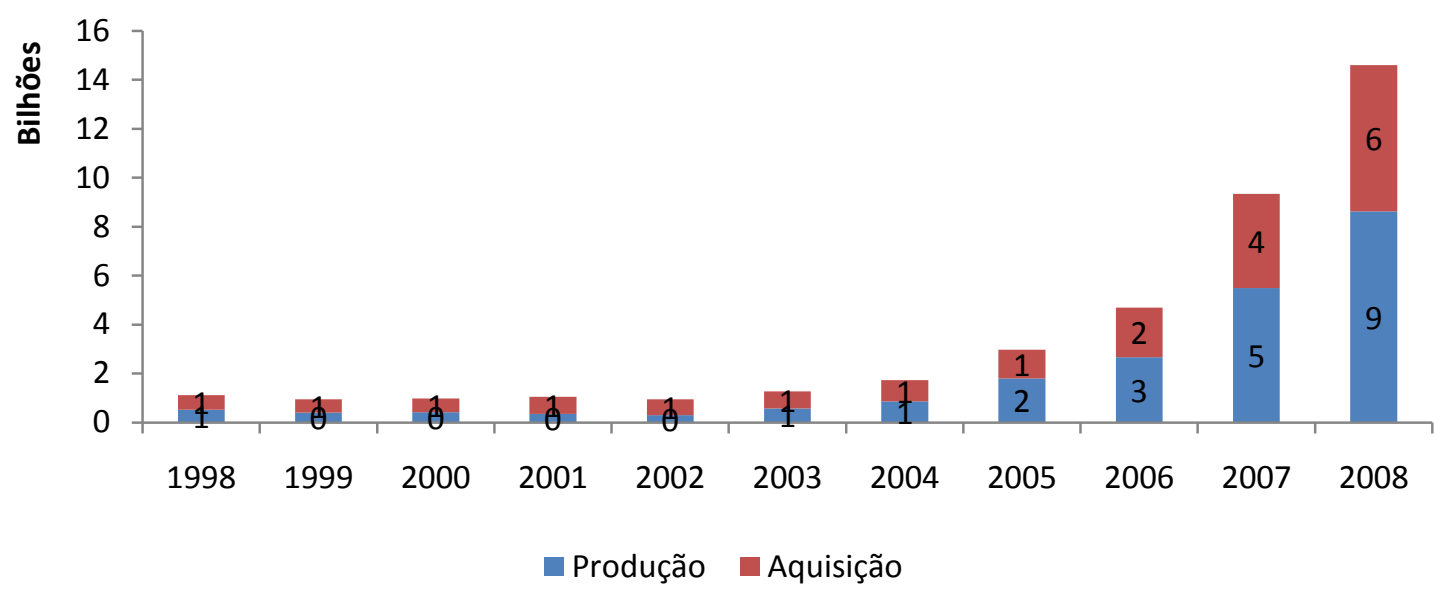

Gráfico 20 - Volume financiado originado no Estado de São Paulo com recursos do SBPE

Fonte: ABECIP

O VMF das unidades produzidas em SP se manteve em geral de 3\% a $17 \%$ acima dos valores no Brasil, e o VMF das unidades financiadas para aquisição de $4 \%$ a $23 \%$ conforme pode ser notado no gráfico a seguir. Mesmo com um maior valor, o VMF das unidades financiadas no estado de São Paulo somente atingiu 35\% do limite previsto por lei.

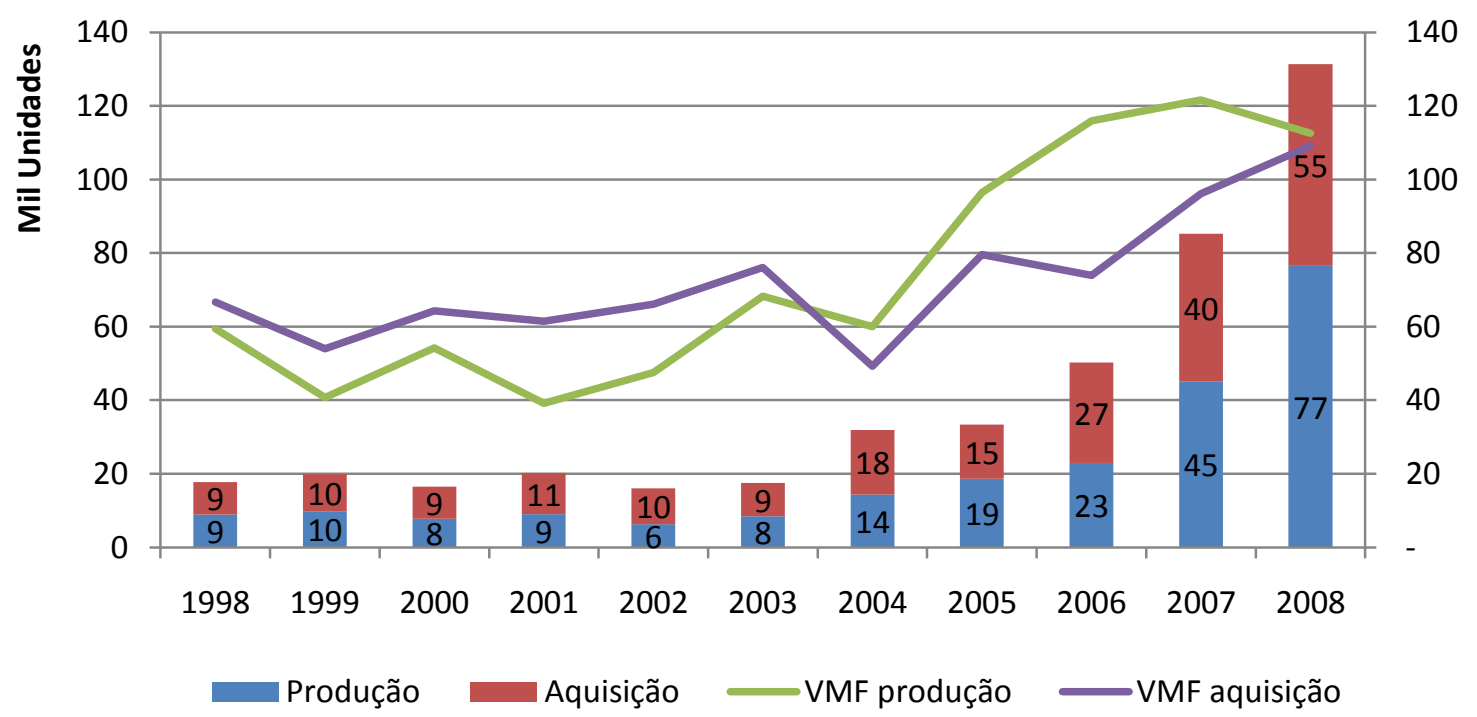

Gráfico 21 - Unidades financiadas originadas no Estado de São Paulo com recursos do SBPE

Fonte: ABECIP 
5.2.5. Originação de financiamento para a produção de unidades novas no $\mathrm{SFH}$

Considerando apenas o FinANCIAMENTO À ProduÇão no Brasil, pode-se notar que o financiamento das unidades novas representa $90 \%$ do total financiado em 2008. Deste total, $91 \%$ se concentraram em unidades dentro dos limites do SFH. No entanto, até 2003, a participação das unidades financiadas a taxas de mercado variou de $25 \%$ a $54 \%$ do total financiado, uma vez que os agentes financeiros não sofriam pressão para cumprir a exigibilidade de aplicação de $65 \%$ dos recursos do SBPE com os créditos do FCVS.

Nos anos subsequientes a participação desta parcela dos financiamentos ficou restrita de $2 \%$ a $9 \%$, demonstrando mais uma vez a forte influência da reversão dos créditos do FCVS pelo governo.

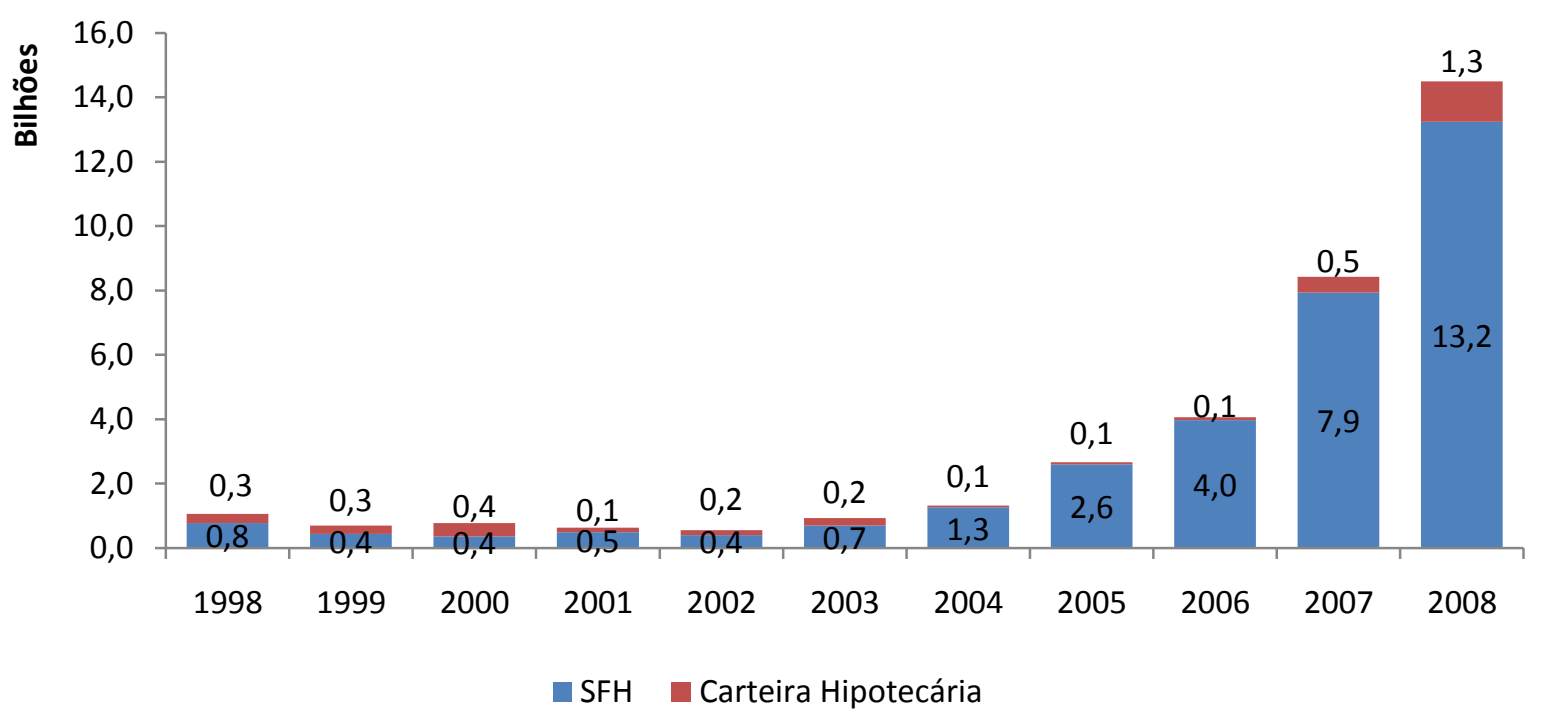

Gráfico 22 - Volume financiado originado no Brasil com recursos do SBPE para a produção de unidades novas

Fonte: ABECIP

Devido ao pequeno número de financiamentos fora dos limites do SFH a partir de 2004, o VMF das unidades oscilou de R\$ 80 mil a valores acima de R $\$ 500$ mil em 
2005. No mesmo período, as unidades dentro do limite do SFH passaram do patamar de $\mathrm{R} \$ 40$ mil para $\mathrm{R} \$ 95$ mil conforme apresentado no gráfico a seguir.

O baixo VMF das unidades dentro dos limites do SFH indica que apenas uma parcela equivalente a no máximo 30\% do limite de Preço está sendo financiado. Segundo a prática de mercado apresentada no item 3.2, os Agentes Financeiros liberam apenas uma parcela de $70 \%$ a $100 \%$ do custo de construção do empreendimento, o que equivale de $40 \%$ a $60 \%$ do Preço. O detalhamento do VMF é apresentado no gráfico a diante.

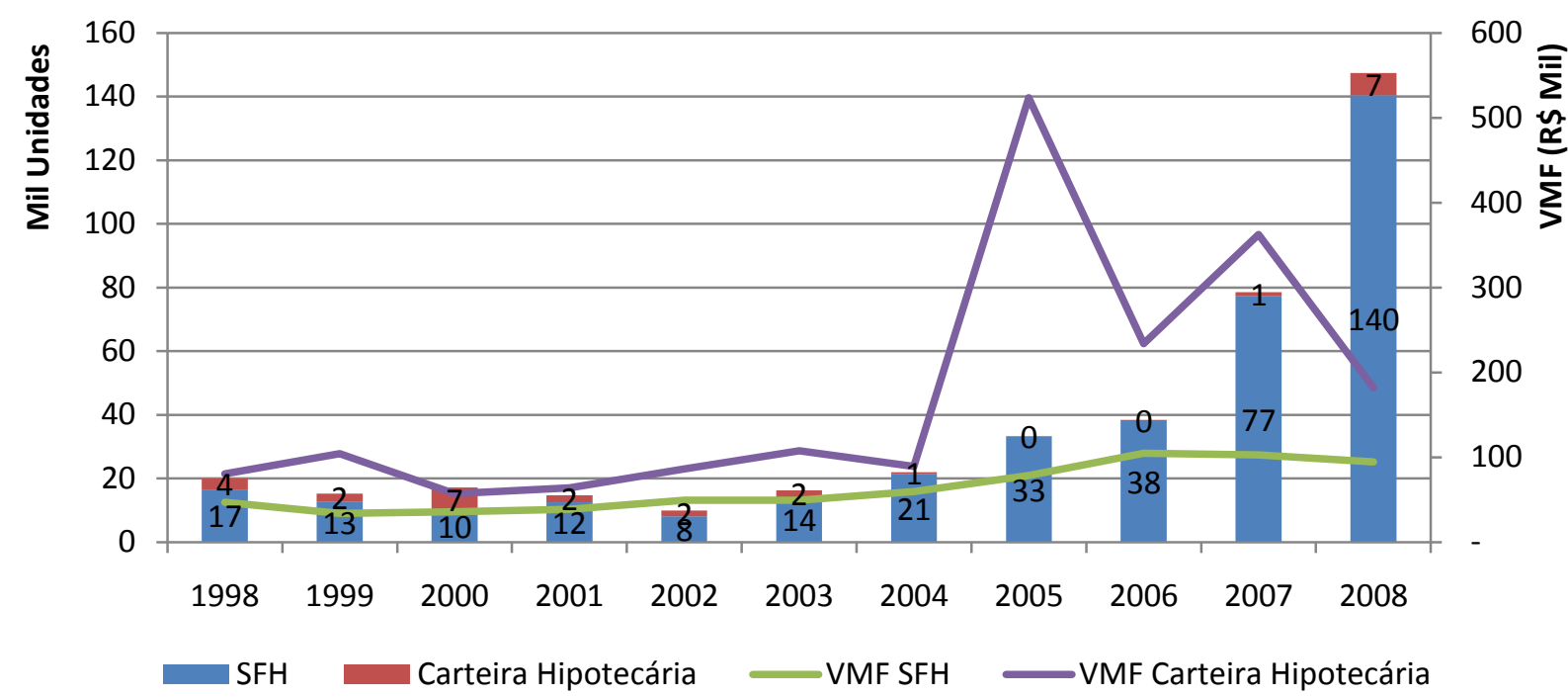

Gráfico 23 - Financiamentos originados no Brasil com recursos do SBPE para a produção de unidades novas

Fonte: ABECIP

5.2.6. Originação de financiamento para aquisição de unidades novas no SFH

Analisando somente as unidades novas para aquisição financiadas no período no Brasil, pode-se notar que estas representam $28 \%$ do total financiado em 2008. Deste total, $70 \%$ se concentraram em unidades dentro dos limites do SFH. No entanto, nos demais anos essa participação flutuou de $60 \%$ a $85 \%$. 
Nota-se ainda que, diferentemente do incremento total no volume de unidades financiadas a partir de 2003, as unidades novas somente tiveram seu ponto de inflexão após 2006. Este comportamento pode demonstrar que o mercado de produção não reagiu instantaneamente às novas condições de oferta de recursos resultado do ciclo de produção do mercado habitacional mencionado anteriormente.

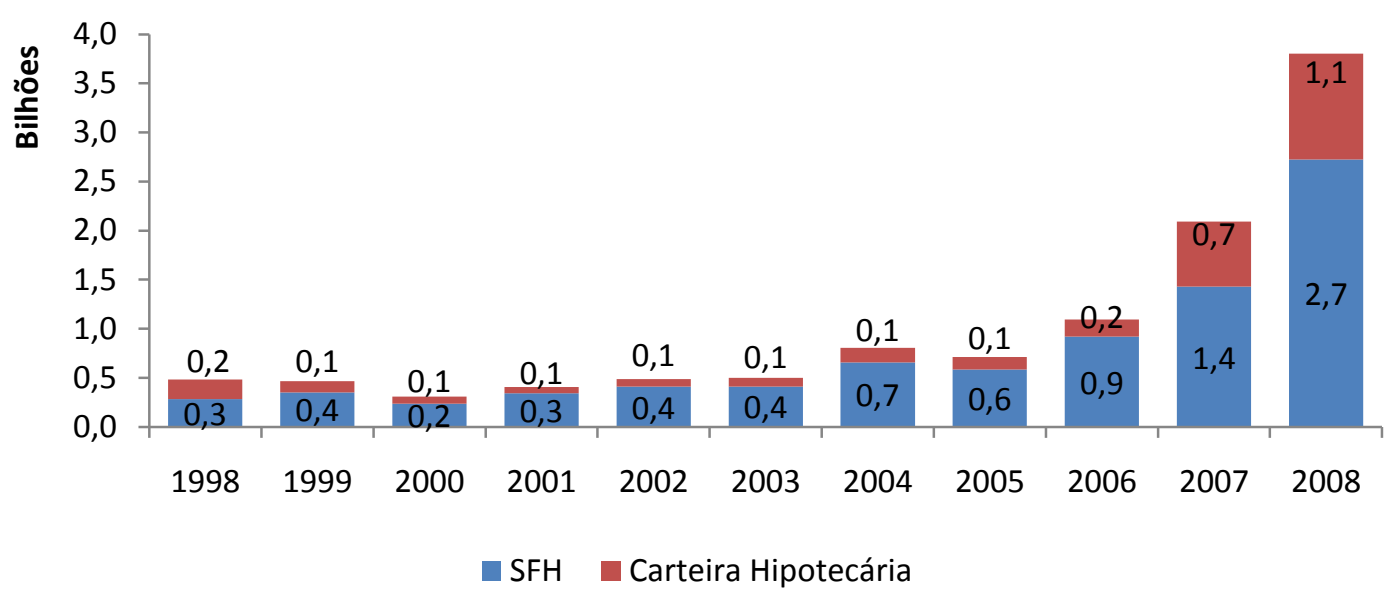

Gráfico 24 - Volume financiado originado no Brasil com recursos do SBPE para aquisição de unidades novas

Fonte: ABECIP

Por sua vez, o VMF das unidades dentro dos limites do SFH passou de R\$ 46 mil em 1998 para R\$ 100 mil no final de 2008. Ao mesmo tempo as unidades dentro da carteira hipotecária, e, portanto, com taxas de juros livres para flutuar de acordo com as condições do mercado passaram de $\mathrm{R} \$ 90$ mil para $\mathrm{R} \$ 233$ mil. 


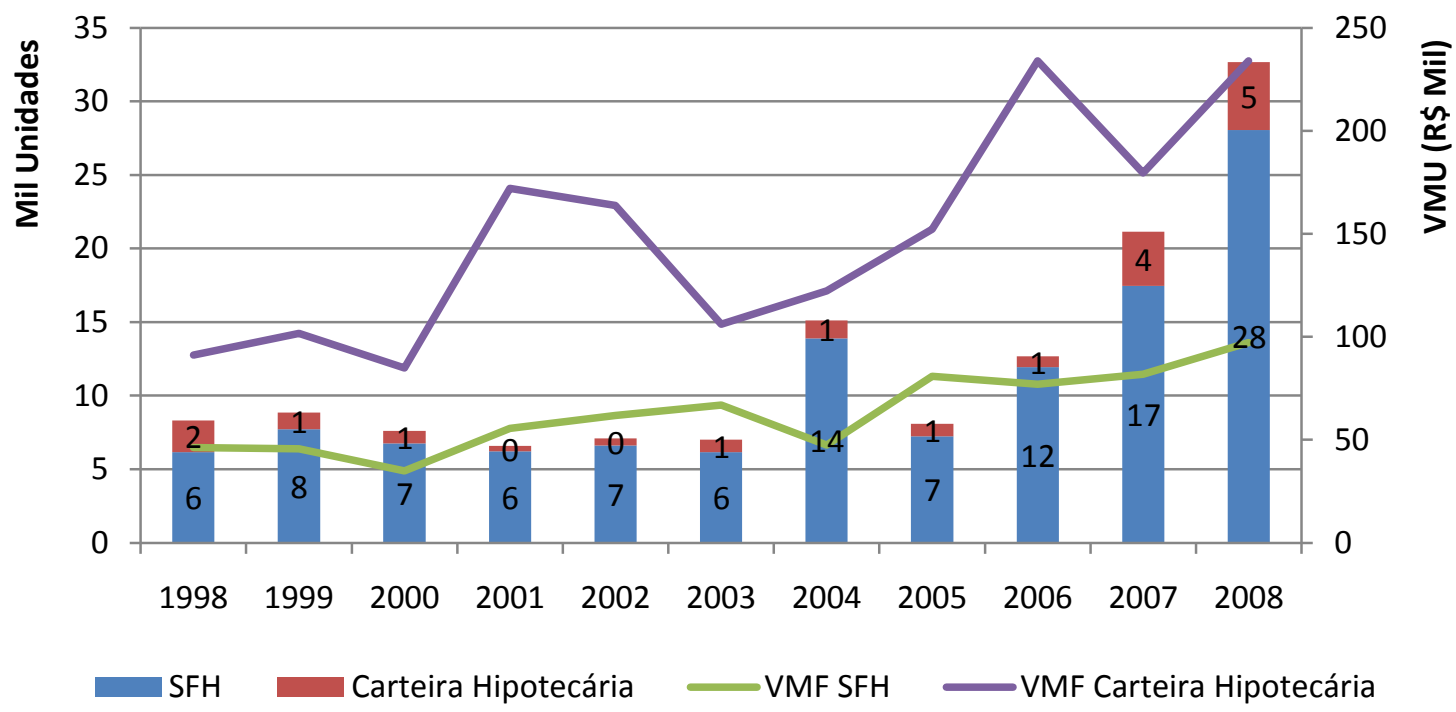

Gráfico 25 - Unidades financiadas originadas no Brasil com recursos do SBPE para aquisição de unidades novas

Fonte: ABECIP

O crescimento exponencial entre os financiamentos originados entre 2005 e 2008 também indica que as unidades produzidas estão sendo comercializadas, o que comprova a demanda habitacional gerada pela formação de domicílios apresentada anteriormente. 
5.2.7. Produção Habitacional Privada na cidade de São Paulo com financiamento à produção

A Produção Habitacional Privada na cidade de São Paulo pelos empreendedores se concentrou em unidades dentro do SFH com um Valor Médio Unitário (VMU) de aproximadamente R\$ 175 mil. As unidades ofertadas fora do limite do SFH apresentaram um valor superior, variando entre $\mathrm{R} \$ 650$ e $\mathrm{R} \$ 880$ mil no período, demonstrando uma clara segregação de públicos. Vale ressaltar que os valores em Reais foram ajustados pelo IPCA e estão expressos em R \$ de 2009.

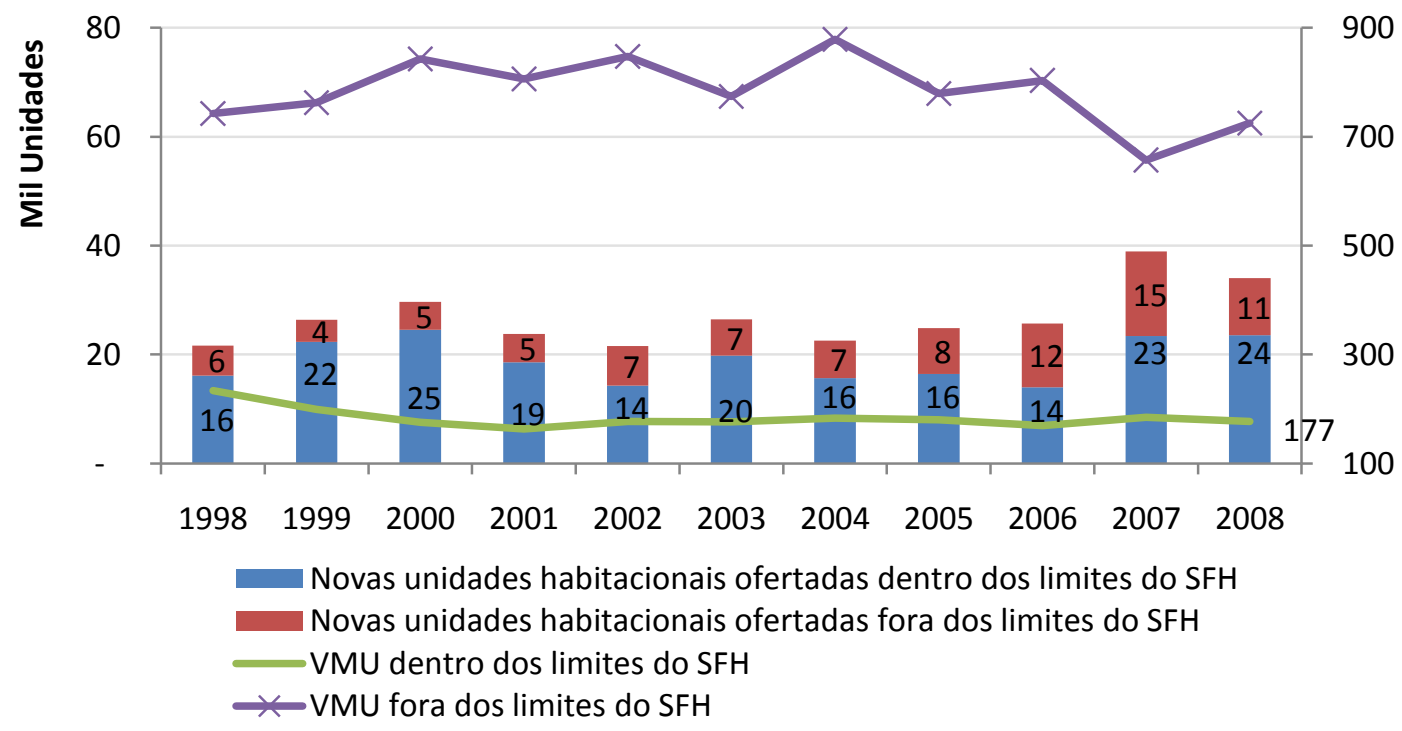

Gráfico 26 - Novas unidades habitacionais ofertadas na cidade de São Paulo segundo o público comprador

Fonte: SECOVI-SP, GEOIMÓVEL, EMBRAESP com adaptações do autor

Analisando a distribuição das novas unidades ofertadas no mercado, nota-se que as unidades mais caras, acima dos limites do SFH apresentaram um crescimento de participação de aproximadamente 25\% para 46\% em 2006, terminando 2008 com $31 \%$. Este comportamento pode ser observado no gráfico a seguir. 


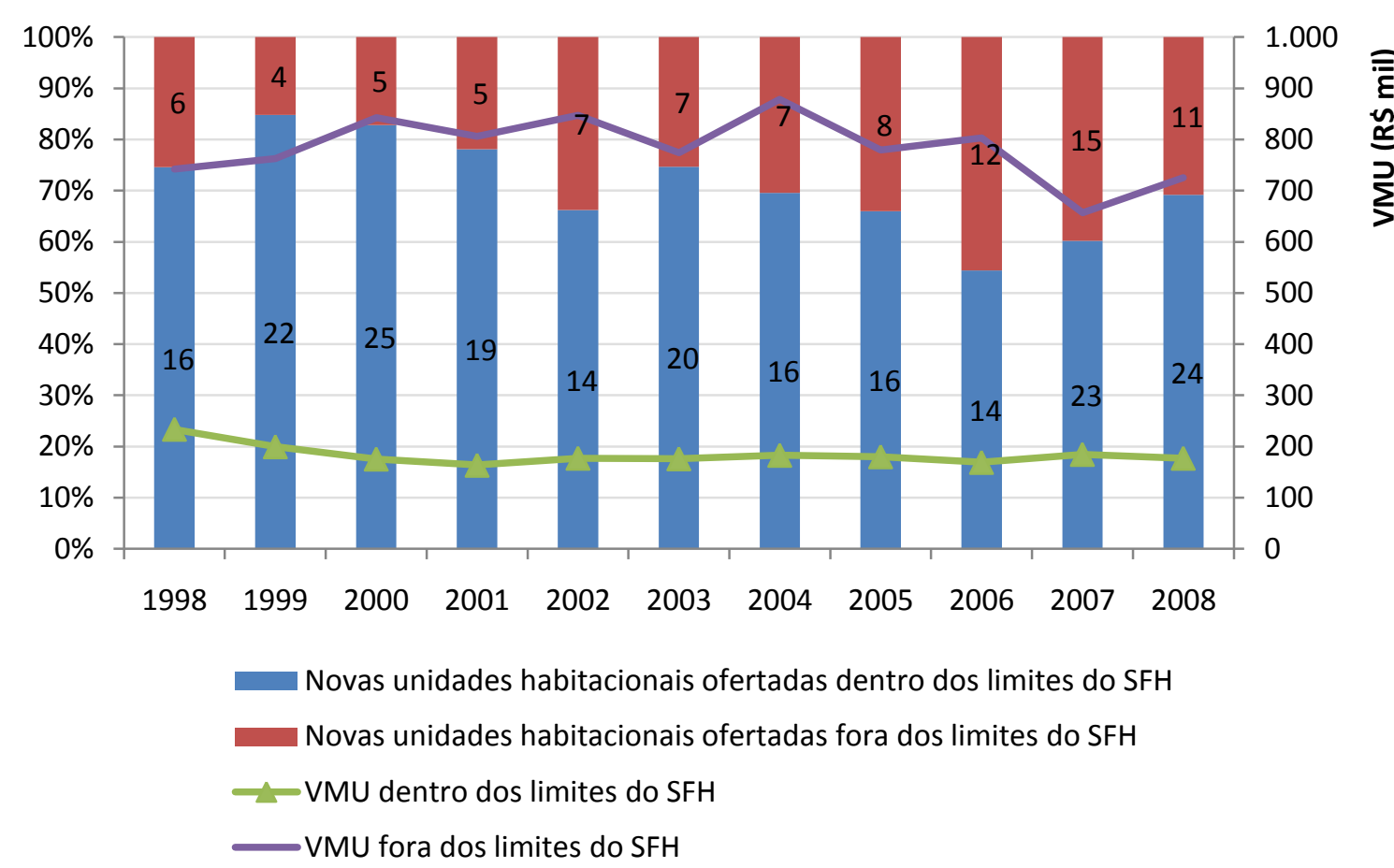

Gráfico 27 - Distribuição de novas unidades habitacionais ofertadas na cidade de São Paulo segundo o público comprador

Fonte: SECOVI-SP, GEOIMÓVEL, EMBRAESP com adaptações do autor

A explicação para esta tendência de oferta de unidades com valores mais altos coincide com a menor necessidade de financiamento de grande parte do preço por parte da população de maior renda. Dessa forma, a restrição de recursos disponíveis no período pode ter levado os agentes produtores a migrar para este nicho de mercado.

Segregando a nova oferta de unidades no período de acordo com a equação de fundos escolhida pelos empreendedores, tem-se que aqueles projetos com apoio de financiamento à produção oscilaram no período partindo de aproximadamente $50 \%$ em 1998 até 60\% em 2001. Após 2002, esse volume ficou restrito entre 35\% e 50\%, ultrapassando os $60 \%$ de participação novamente apenas em 2008, demonstrando mais uma vez a restrição de recursos que os agentes produtores enfrentaram no período. Este comportamento é apresentado no gráfico a seguir. 


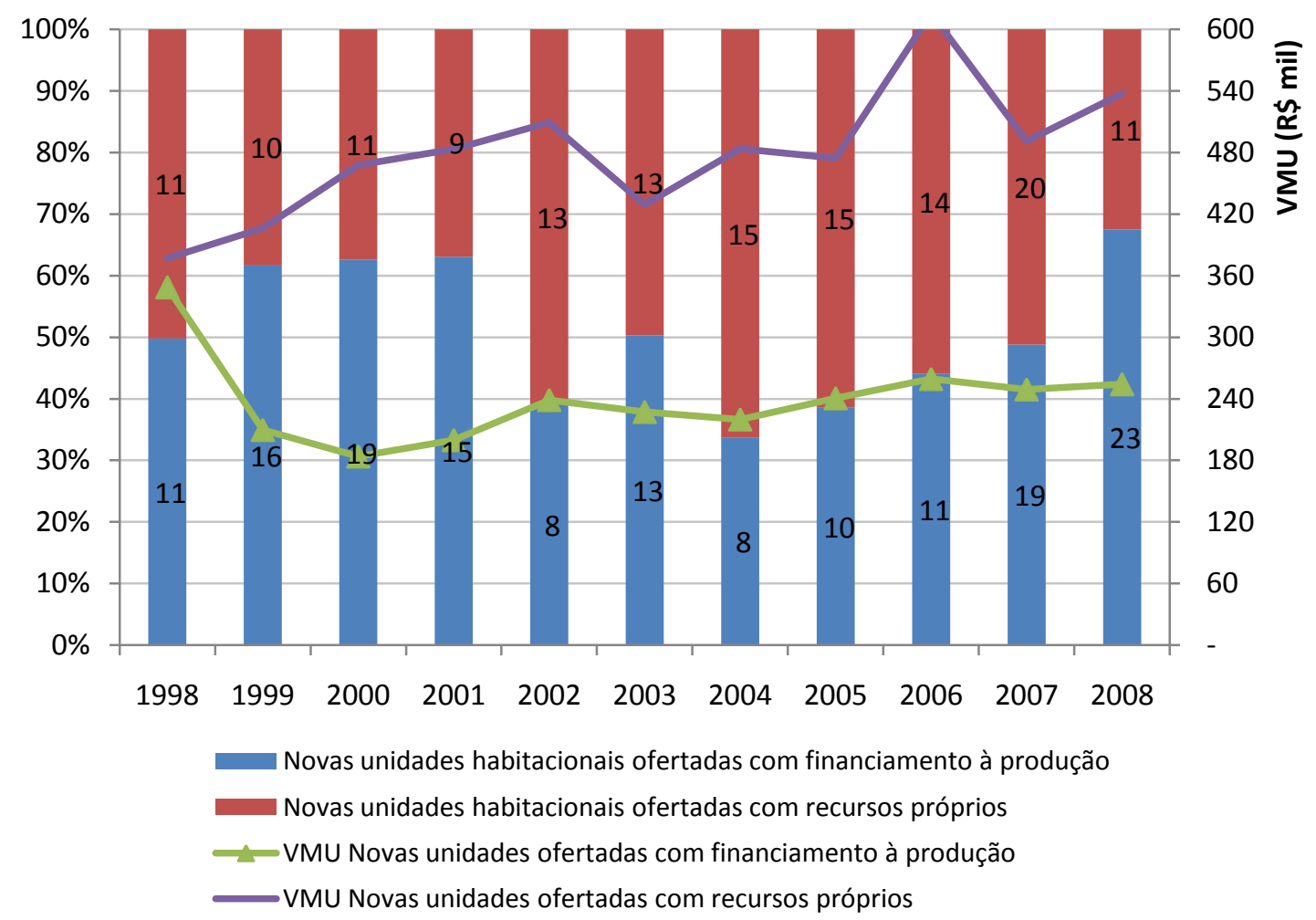

Gráfico 28 - Distribuição das unidades lançadas na cidade de São Paulo segundo a origem dos recursos

Fonte: SECOVI-SP, GEOIMÓVEL, EMBRAESP com adaptações do autor

O VMU das unidades produzidas com financiamento à produção oscilou no período entre $\mathrm{R} \$ 180$ mil e 240 mil, dentro do limite do SFH o que indica a possibilidade de enquadramento nos $65 \%$ de aplicação do saldo do SBPE. Ao mesmo tempo, as unidades produzidas com recursos próprios oscilaram entre $\mathrm{R} \$ 400$ mil e $\mathrm{R} \$ 600 \mathrm{mil}$ no período, acima do limite do SFH e somente elegíveis aos recursos mais escassos da carteira hipotecária. Esse comportamento contribui para a explicação que com a falta de recursos do SBPE os empreendedores migraram para o nicho de mercado onde os consumidores não necessitassem de financiamento de longo prazo.

Conforme os dados apresentados deve-se destacar a ineficiência do SFH no período para prover recursos ao setor, não cumprindo assim seu principal objetivo, e indicando mais uma vez o espaço para novas fontes de recursos para promover o crescimento da produção habitacional. 


\subsection{Histórico do Sistema Financeiro Imobiliário (SFI)}

Com o objetivo de incorporar novas fontes de recursos para o setor imobiliário, foi criado pela lei $n^{\circ} 9.541$ de 20 de novembro de 1997 o Sistema Financeiro Imobiliário (SFI). O SFI fundamenta-se na securitização dos créditos imobiliários para captar recursos de investidores, e para isso implementou mecanismos importantes para fortalecer as garantias das operações de crédito como a alienação fiduciária. A alienação fiduciária aumentou a liquidez das operações tornando a retomada dos imóveis mais rápidas em caso de inadimplência.

Pode-se destacar dentre os instrumentos criados pelo SFI os Certificados de Recebíveis Imobiliários (CRIs), as Letras de Crédito Imobiliário (LCI) e as Células de Crédito Imobiliário (CCI), os quais representam títulos lastreados em contratos de financiamento imobiliário, com o imóvel servindo como garantia da operação.

A partir dos instrumentos citados, foi possível criar o ambiente para o desenvolvimento do mercado secundário, no qual investidores poderiam negociar seus títulos em um mercado organizado, criando assim a liquidez necessária para atrair investidores institucionais, estrangeiros.

A inspiração para a criação do SFI, apoiado em um forte mercado secundário, venho do modelo norte americano implementado em 1938 após a Grande Depressão de 1929. Naquele momento houve a criação da agência securitizadora Fannie Mae a qual tinha por objetivo garantir liquidez para o mercado primário de hipotecas e incentivar o aumento da sua utilização no mercado imobiliário. A Fannie Mae operou como uma agência estatal durante 30 anos, mas se tornou privada em 1968. O volume de negócios no mercado secundário de hipotecas americano atinge o volume de US\$ 1 trilhão de dólares anualmente.

Esse nível de atividade, segundo Vasconcelos (1996), só foi possível devido à padronização das alternativas de investimentos encontradas no mercado secundário 
de hipotecas. Essa homogeneidade dos papéis garante transparência e maior grau de percepção do investidor sobre a rentabilidade real dos investimentos. O principal objetivo do SFI é captar recursos do mercado de capitais, interna e externamente, atingindo as poupanças privadas e institucionais.

A condição fundamental para o sistema é a estabilidade econômica, oferecendo a credibilidade necessária aos investidores para aportar recursos a longo prazo e a taxas de juro menores. A história do SFH mostrou que a elevação da inflação para o patamar de três dígitos foi responsável por descasamentos que acabaram inviabilizando o sistema.

As operações de originação no SFI foram limitadas nos primeiros anos após sua criação. A emissão primária de recebíveis imobiliários atingiu somente em 2005 o volume total de R\$ 2,1 bilhões e em 2006 de R\$ 1,1 bilhão, decaindo nos anos subseqüentes. Segundo a CVM, esses volumes correspondem, basicamente, a títulos de financiamentos lastreados em imóveis comerciais. A participação do crédito habitacional no SFI no período não foi significativa, ficando restrita a operações não representativas realizadas pelos bancos comerciais.

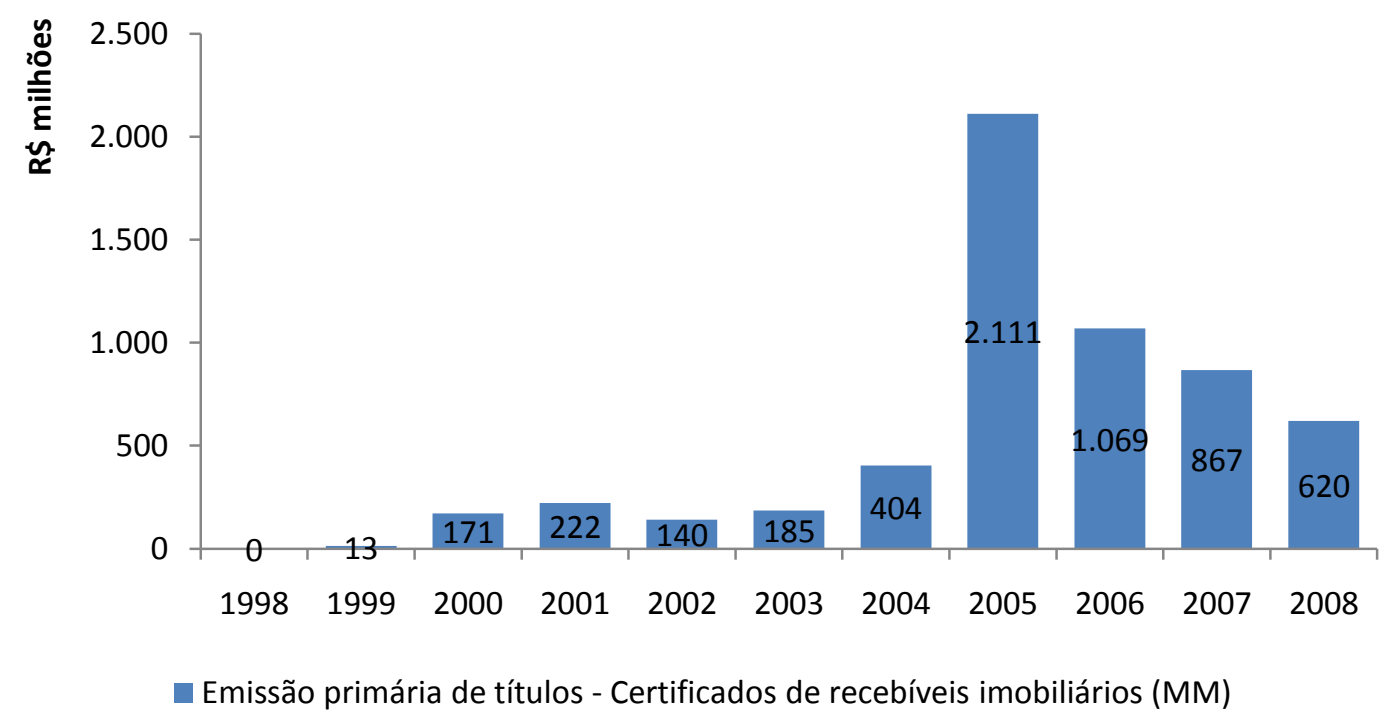

Gráfico 29 - Emissão primária de Certificados de Recebíveis Imobiliários (CRI)

Fonte: ABECIP 
Outras mudanças objetivaram contribuir para o desenvolvimento do mercado secundário. Entre as medidas pode-se destacar a desoneração tributária, que compreende a isenção de imposto de renda dos ativos detidos por pessoas físicas associados à Letras Hipotecárias, os CRIs e LCI, por meio da Lei 11.033 de 19 de janeiro de 1999.

Outra medida importante foi à resolução 3.456 de 1 de junho de 2007, realizada pelo Conselho Monetário Nacional, que autorizou o aumento da proporção dos CRIs que podem ser adquiridos pelos fundos de pensão, estimulando o principal instrumento de captação do SFI.

Mesmo com essas medidas, o mercado secundário ainda está em desenvolvimento. No período selecionado não houve um volume significativo de operações, resultado das emissões de baixo valor e o baixo volume de ofertas de investidores interessados nos títulos. Segundo dados da BOVESPA, em 2006 e 2007 houve uma movimentação de $\mathrm{R} \$ 252$ milhões e R 176 milhões respectivamente.

Dentre as razões para este comportamento, pode-se citar o uso da Taxa Referencial (TR) nos créditos habitacionais financiados dentro do $\mathrm{SFH}$, o qual reajusta a caderneta de poupança do SBPE - fonte de recursos destes financiamentos. A TR, por sua vez, tem uma variação inferior aos demais índices que acompanham o movimento da inflação nacional, como o IGPM ou o IPCA. Para equilibrar o ativo e passivo das operações sem buscar custos adicionais, o indexador dos contratos com os mutuários e da remuneração para os investidores deve ser o mesmo. Dessa forma, a originação de CRIs fica comprometida, uma vez que para o mutuário é mais vantajoso financiar o seu imóvel dentro do SFH com sua dívida indexada na TR.

Além disso, a falta de padronização dos contratos e a ausência do cadastro positivo tornam o empacotamento dos contratos de financiamento imobiliário mais difícil, prejudicando a diluição de riscos de concentração de contratos em um determinado perfil e a obtenção de volumes atrativos. As regras que determinam as taxas de juros, o valor do imóvel, uso comercial ou residencial, novo ou usado, prazos de 
financiamento e os limites de comprometimento da renda dos mutuários devem resultar em um padrão de risco e retorno a ser determinado pelo mercado comprador dos títulos.

Visando aumentar as operações do mercado secundário, algumas iniciativas foram tomadas nos últimos anos, como a utilização dos recursos do SBPE e do FGTS para gerar a liquidez necessária para este mercado. Está previsto no orçamento de 2008 a 2011 do FGTS a utilização de recursos para aquisição de CRIs. No entanto, a utilização dos recursos do SBPE e FGTS, os quais representam as fontes de recursos do SFH, não resultariam em acréscimo de recursos ao sistema, contrariando assim o objetivo do mercado secundário. Utilizando este raciocínio, os recursos alocados na aquisição de títulos concorreriam com as aplicações em novos financiamentos.

\subsection{Acesso aos recursos do mercado de capitais}

Ainda buscando atrair recursos do mercado de capitais, foram instituídas outras ferramentas para operacionalizar o investimento no setor imobiliário, como o Fundo de Investimento em Participações (FIP) e o Fundo de Investimento Imobiliário (FII). Um instrumento implantado mais recentemente, a lei $\mathrm{n}^{\circ} 10.931$ de 2004 que criou o patrimônio de afetação, possibilitou a segregação do patrimônio e das obrigações do empreendedor de cada empreendimento imobiliário que este promovesse. A empresa que optasse pela modalidade de patrimônio de afetação durante o desenvolvimento de um empreendimento teria a contabilidade segregada e individualizada em cada projeto. Dessa forma, os compradores dos empreendimentos teriam uma maior segurança no momento da compra e, caso tivessem adquirido uma unidade de uma empresa com dificuldades financeiras, poderiam substituir a empresa por outra objetivando o término da construção. Além da vantagem aos compradores, essa segregação de patrimônio contribui para atrair recursos de investidores para os projetos específicos, segregando o risco do empreendimento do risco da empresa.

Conforme apresentado no gráfico a seguir, os volumes de CRI, FIP e FII não foram representativos no período selecionado. Vale destacar que a emissão primária pública 
total de quotas de fundos nos diversos mercados não superou o montante de $\mathrm{R} \$ 1$ bilhão entre 1998 e 2008.

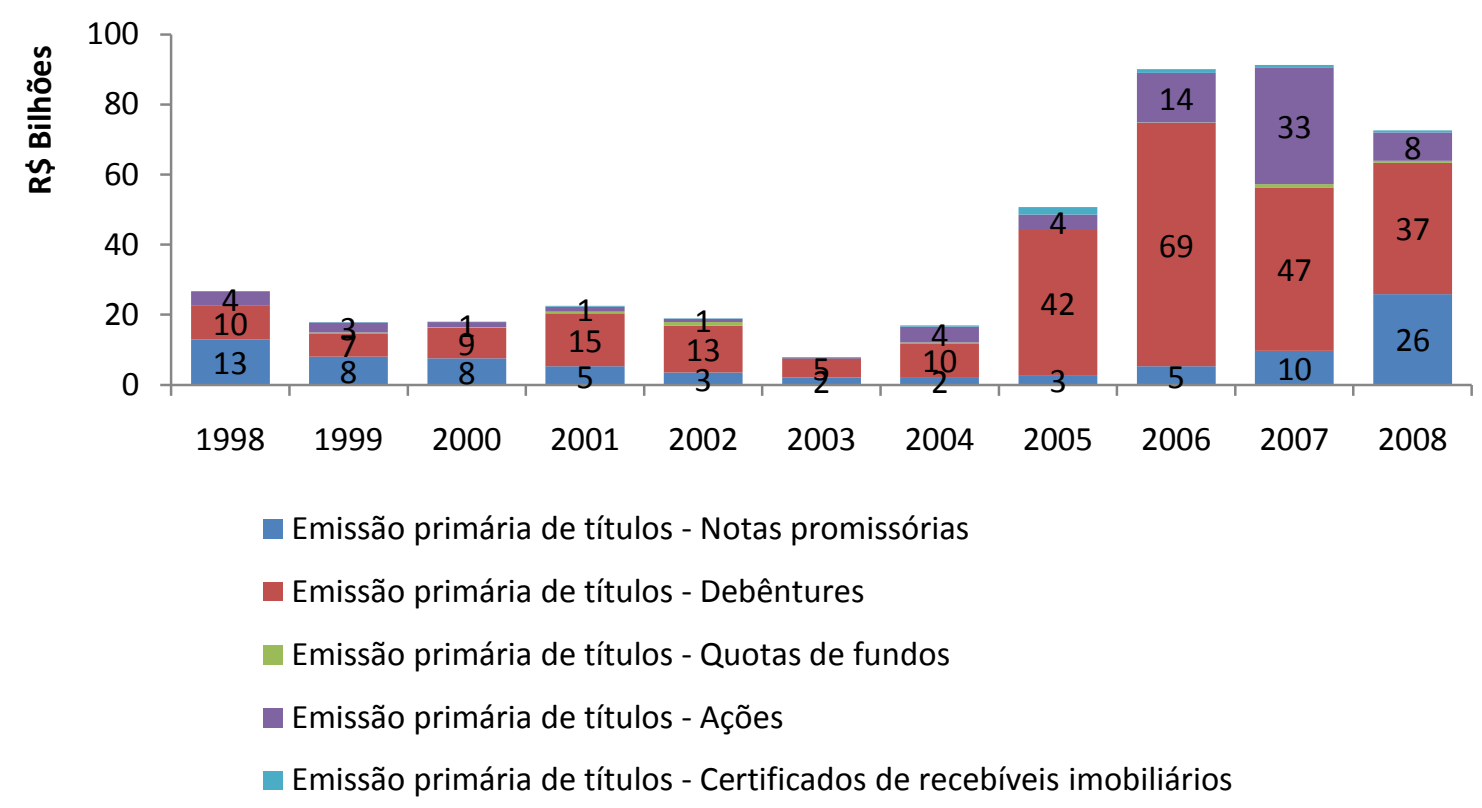

Gráfico 30 - Acesso aos recursos do mercado de capitais

Fonte: CVM

De acordo com o gráfico apresentado, os instrumentos mais utilizados no período para acesso ao mercado de capitais foram a emissão de (i) Debêntures, (ii) Notas promissórias e (iii) Ações. Os dois primeiros instrumentos representam operações fundamentadas em dívidas, com garantias definidas e padrões de risco controlados. Nota-se que, após oscilar em um patamar de aproximadamente R \$ 20 bilhões de 1998 a 2002, em 2003 seu volume foi reduzido para apenas R\$ 7 bilhões. A partir de 2004 é iniciada uma retomada, onde à emissão de debêntures supera o volume médio de R \$ 40 bilhões anuais e a de notas promissórias de $\mathrm{R} \$ 9$ bilhões anuais.

No caso das ações nota-se que desde 2004 foi captado um total de R \$ 64 bilhões de recursos novos para o mercado como um todo. O ano de 2007 foi responsável por mais da metade deste volume. Entre 2006 e 2007, 19 empresas focadas no desenvolvimento de empreendimentos imobiliários habitacionais também foram ao mercado de capitais e captaram $\mathrm{R} \$ 13$ bilhões em novos recursos por meio da oferta pública de ações. 
A abertura de capital proporcionou a estas empresas o acesso a recursos alternativos ao SFH, antes indisponíveis como, por exemplo, a emissão de debêntures. Em 2007, as debêntures emitidas pelas empresas de capital aberto do setor da construção civil somaram aproximadamente $\mathrm{R} \$ 1,4$ bilhões.

No gráfico a diante, são segregadas as empresas que realizaram Oferta Pública de Ações (OPA) a partir de 2006. Nota-se de acordo com o gráfico que antes de acessar os recursos do mercado de capitais essas empresas produziram na cidade de São Paulo entre 6 e 9 mil unidades por ano. A partir de 2006, essas empresas ampliaram sua capacidade produtiva passando a lançar em 2007 e 2008 aproximadamente 12 e 19 mil unidades respectivamente, o que representa mais de $100 \%$ de incremento.

No mesmo período as empresas limitadas (ltdas) oscilaram a produção entre 15 mil e 22 mil unidades, produzindo o mesmo volume de 15 mil unidades em 1998 e 2008. Diante dos dados pode-se concluir que o incremento na produção de unidades ocorreu somente na parcela de empresas que aumentaram sua capacidade produtiva mediante o ingresso de recursos do mercado de capital.

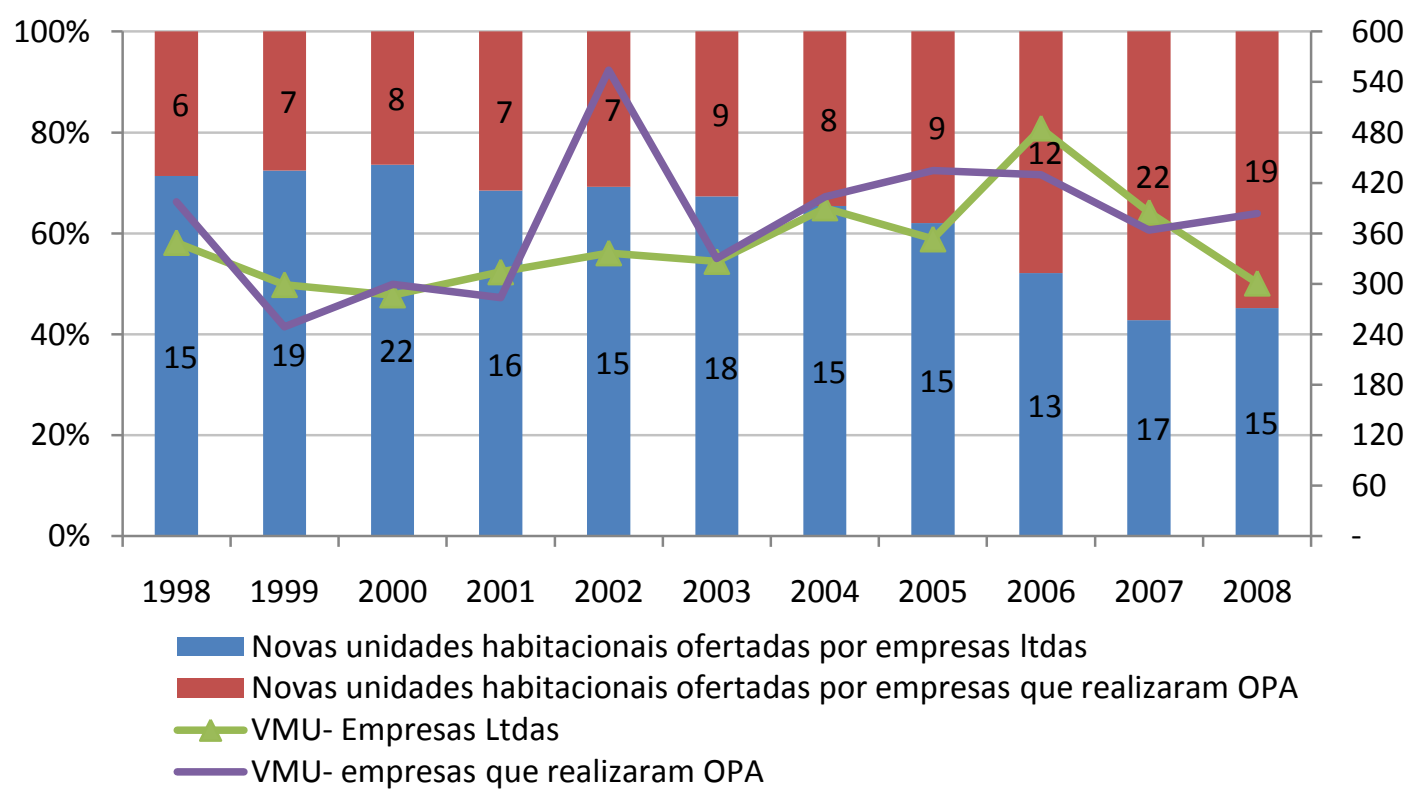

Gráfico 31 - Distribuição das novas unidades habitacionais ofertadas na cidade de São Paulo segundo a estrutura de capital da empresa

Fonte: SECOVI-SP, GEOIMÓVEL, EMBRAESP com adaptações do autor 
Analisando o comportamento do VMU das unidades lançadas, nota-se que seu valor oscilou simultaneamente entre a faixa de R \$ 300 mil e 480 mil, a exceção de 2002 onde houve uma concentração em unidades com valores mais altos por parte das empresas que viriam a realizar OPA em 2002. Vale ressaltar que em 2008 há uma redução no VMU das unidades lançadas pelas empresas ltdas, o que pode indicar uma diversificação de produto para manter a competitividade com as empresas que realizaram OPA.

Além dos recursos levantados no mercado de capitais, estas empresas ainda recorreram a outras modalidades de dívidas para promover seu crescimento. Considerando os dados retirados dos resultados operacionais publicados ao final do segundo trimestre de 2009 pelos empreendedores de capital aberto, tem-se que a estrutura de capital utilizada para promover o crescimento apresentado no gráfico anterior foi de $31 \%$ de endividamento com o SFH, 36\% em debêntures, $26 \%$ em capital de giro e $7 \%$ de outros tipos de financiamento.

Esses dados demonstram que o crescimento da participação dessas empresas na produção habitacional da cidade de São Paulo foi impulsionado principalmente pelos recursos do mercado de capitais que foram responsáveis por aproximadamente $70 \%$ da estrutura de dívida. Considerando que o endividamento médio dessas empresas é de $46 \%$, o SFH representou ao final de 2008 apenas $15 \%$ da equação de fundos utilizada.

5.5. Comportamento da produção de unidades frente à oferta de recursos

Como apresentado, a OfERTA DE RECURSOS no período selecionado pode ser dividida entre (i) fontes oficiais e instrumentos específicos do setor habitacional (SFH e SFI) e (ii) outros instrumentos ligados ao mercado de capitais comum aos demais setores, as quais apresentaram significativa mudança no período selecionado. 
De forma resumida, tem-se que até 2004 o SFH foi responsável pela totalidade dos recursos disponíveis para as atividades do setor habitacional e conseqüentemente pelas originações no período, somando aproximadamente $\mathrm{R} \$ 14$ bilhões em 7 anos. Além disso, as novas operações estavam limitadas ao saldo de recursos do SBPE que até 2004 apresentou uma retração, principalmente devido aos créditos do FCVS que consumiram a utilização da exigibilidade de direcionamento dos recursos.

A partir de 2004, o saldo do SBPE iniciou uma tendência de incremento, que se traduziu no aumento de operações a partir de então até o final do período selecionado, acumulando R\$ 62 bilhões em 4 anos. Além disso, a partir de 2005, a condição econômica do país também facilitou a entrada de recursos do mercado de capitais para a economia de forma geral beneficiando todos os setores da cadeia produtiva brasileira.

No mercado de empreendimentos habitacionais não foi diferente, e nos anos subseqüentes as empresas se beneficiaram com as emissões primárias de ações, o que possibilitou o aumento da escala de seus negócios. Além disso, essas empresas tiveram acesso ao mercado de dívida, com emissões de debêntures e notas promissórias, impulsionando seu crescimento. De 2006 a 2008 o volume captado no mercado de capitais acumulou aproximadamente $\mathrm{R} \$ 18$ bilhões, sendo $\mathrm{R} \$ 13$ bilhões em investimentos nas empresas e $\mathrm{R} \$ 5$ bilhões em instrumentos de dívidas. 
Conforme representado no gráfico a seguir, a retomada das originações dentro do SFH a partir de 2005 foi capaz de estabilizar o mercado para o patamar anterior a contração do crédito. No entanto, a elevação do nível da produção só foi possível a partir de 2006 com o acesso ao mercado de capitais pelas empresas.

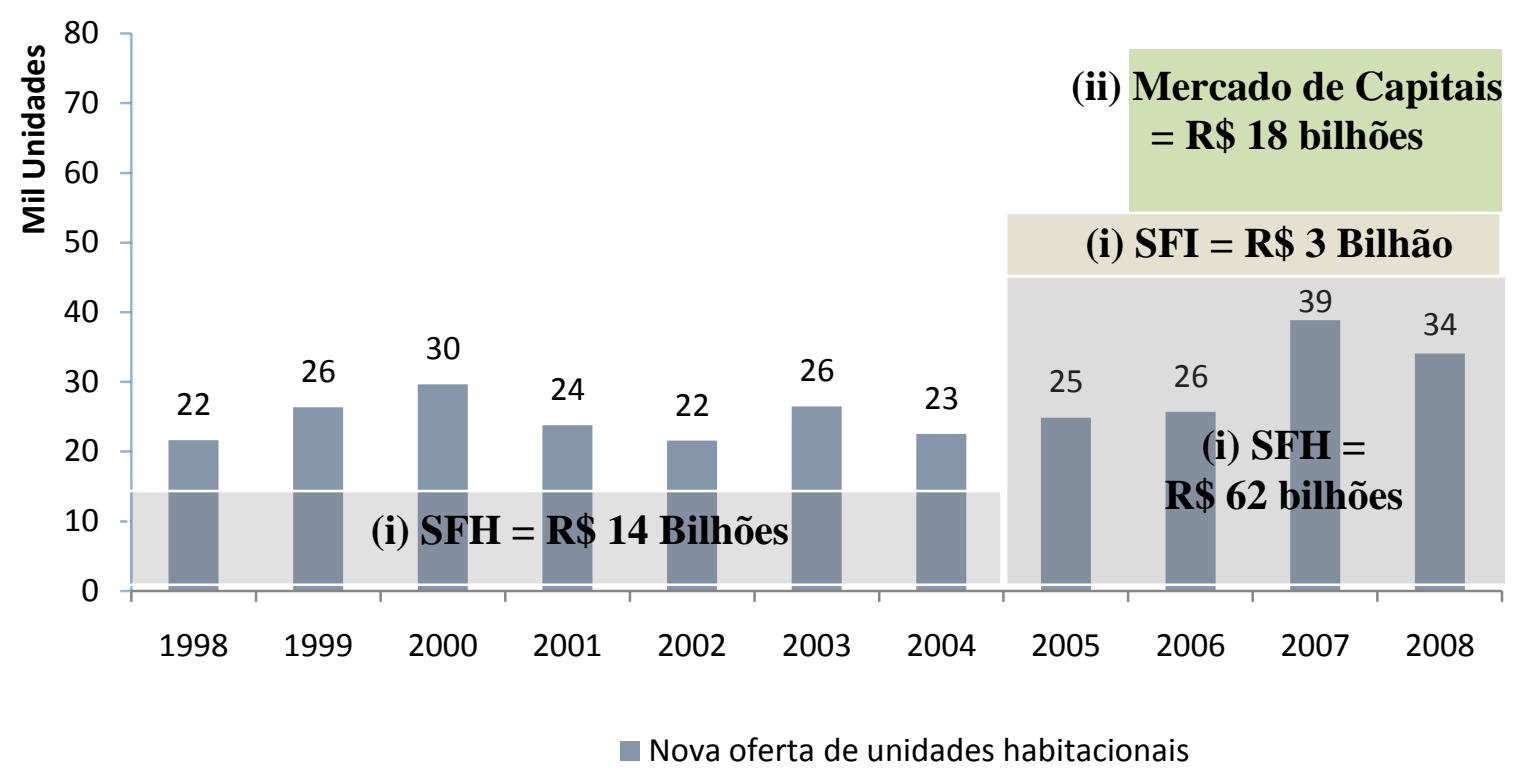

Gráfico 32 - Novas unidades habitacionais ofertadas e a originação de financiamentos por fonte de recursos

Apesar de o SFI ter sido criado em 1997, o esquema apresentado não menciona seu volume originado até 2005 uma vez que, conforme apresentado anteriormente, seus volumes não foram significativos para influenciar a mudança da atividade de produção. Seguindo o mesmo critério, não é apresentado no gráfico o volume originado no mercado de capitais até 2006.

Apenas como referência, até 2005 o SFI originou menos de R\$ 1 bilhão de títulos lastrados em financiamento habitacional. A partir de 2005 sua atividade sofreu um incremento, acumulando $\mathrm{R} \$ 3$ bilhões originados em 4 anos. 
De acordo com a análise apresentada, a variável OFERTA DE RECURSOS, apesar de não ser apresentada em destaque nas bibliografias sobre o assunto, apresentou grande influência no comportamento da PRODUÇÃO HABITACIONAL, e, portanto, na interpretação de seus movimentos. O comportamento da Oferta de Recursos frente à Produção Habitacional pode ser generalizado conforme o esquema apresentado na seqüência. O coeficiente de correlação de Pearson (r) resultou em um valor de 0,73 , o que representa uma forte correlação positiva.

\begin{tabular}{c|c|cc}
\multirow{2}{*}{$\begin{array}{c}\text { Oferta de } \\
\text { Recursos }\end{array}$} & \multicolumn{3}{|c}{ Produção Habitacional Privada } \\
\cline { 2 - 4 } & Premissa & Observado & $\mathrm{r}$ \\
\hline$\uparrow$ & - & $\uparrow$ & 0,73 \\
& & &
\end{tabular}

\subsection{Gastos com Serviços Habitacionais}

Conforme discutido no item 5.1.2 o sistema de FinANCIAMENTO HABITACIONAL sofreu com o impacto da inflação descontrolada na década de 80 causando a insolvência do sistema. Dessa forma, quanto maior o prazo do financiamento, maior seria o horizonte de incertezas que as instituições financeiras iriam enfrentar ao conceder um empréstimo.

Outro ponto que influenciava negativamente a concessão dos financiamentos era a forma de garantia. Somente após a criação do patrimônio de afetação as instituições financeiras puderam exercer a garantia no caso de inadimplência, retomando o imóvel.

De acordo com a pesquisa realizada, as condições de FINANCIAMENTO HABITACIONAL no período podem ser divididas em dois momentos. De 1998 a 2003 os financiamentos tinham um prazo que oscilava de 10 a 15 anos e o comprometimento de renda domiciliar mensal de $20 \%$ a $25 \%$ com o valor da parcela. A partir de 2005, com o início da estabilidade econômica e o aumento da pressão de direcionamento 
dos recursos do SBPE foi iniciada uma flexibilização das condições de financiamento, com os prazos máximos passando para 20 a 30 anos e o comprometimento máximo de $25 \%$ a $30 \%$ da renda com o valor da parcela.

A fim de ilustrar o aumento do poder de compra do consumidor devido à mudança das condições de financiamento, o gráfico a seguir ilustra o faixa da renda mínima necessária em SM de 2008 para adquirir um imóvel de R \$ 130 mil no período em R \$ de 2009.

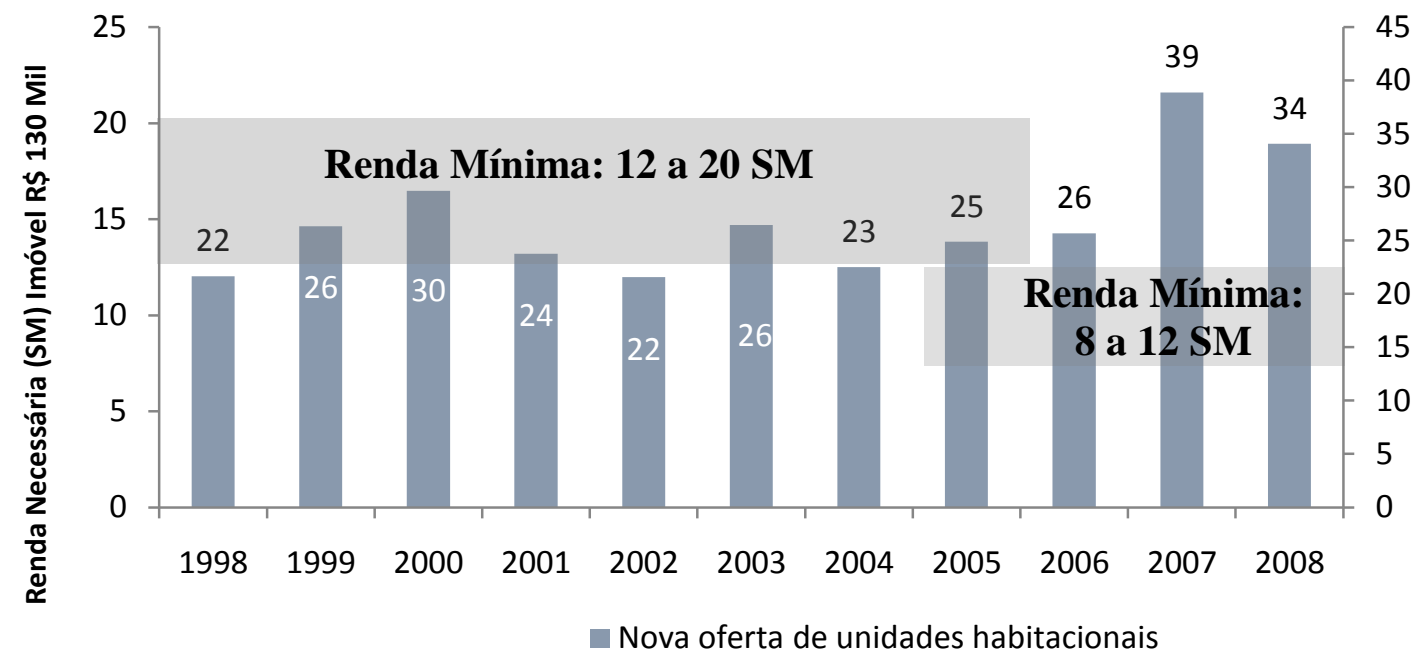

Gráfico 33 - Evolução da renda mínima necessária para o financiamento de uma unidade de $\mathrm{R} \$ 130$ mil em $\mathrm{R} \$$ de 2009 e a nova oferta de unidades habitacionais

Conforme apresentado, a renda mínima necessária para a aquisição de um imóvel de R\$ 130 mil reduziu de 12 a 20 SM até 2004 para 8 a 12 SM a partir de então, aumentando significativamente a base da população que teria acesso a um imóvel deste valor. Pode-se notar que a partir de 2007 as novas unidades ofertadas já apresentaram um aumento significativo. 
O comportamento desta variável é ilustrado no esquema abaixo e o valor de seu coeficiente de correlação de Pearson (r) é de $-0,66$, o que indica uma correlação negativa moderada.

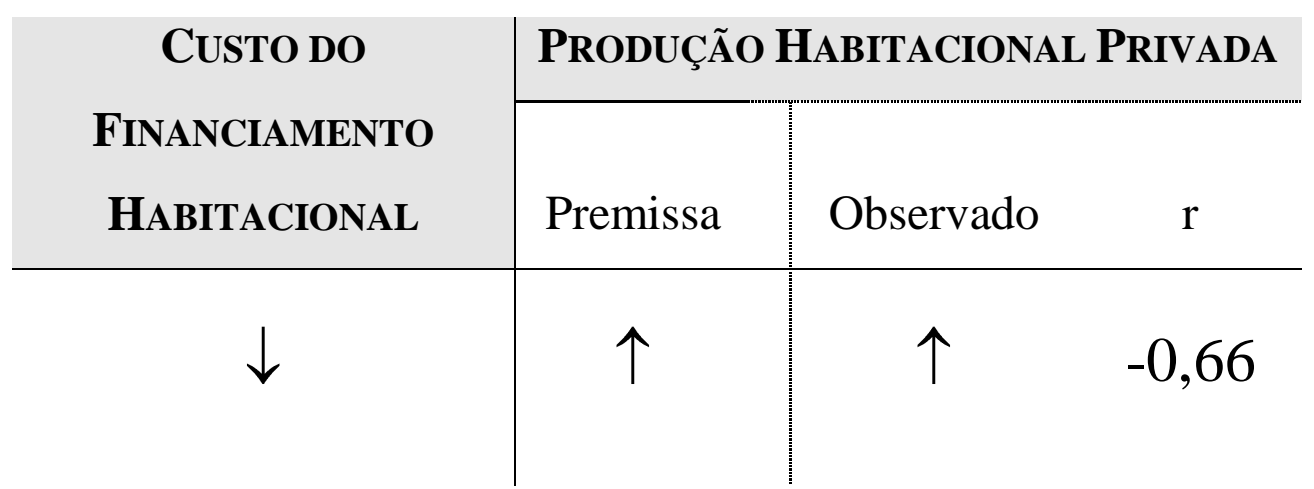

\section{COMPORTAMENTO DAS DEMAIS VARIÁVEIS SELECIONADAS}

A seguir são apresentados os comportamentos das demais variáveis na PRODUÇÃo HABITACIONAL PRIVADA.

\subsection{Preço}

A seguir é apresentado comportamento do preço médio por $\mathrm{m}^{2}$ e do VMU das novas unidades ofertadas na cidade de São Paulo. Os valores apresentados foram ajustados pelo IPCA e estão expressos em $\mathrm{R} \$$ de 2009 . O cálculo do preço por $\mathrm{m}^{2}$ foi obtido por meio da divisão entre o valor total ofertado histórico dos projetos e a área total das unidades ofertadas. O cálculo do VMU foi realizado da mesma maneira substituindo o denominador da divisão mencionada anteriormente pelo número de unidades ofertadas.

Analisando o gráfico a seguir é possível notar a tendência de ligeira queda no preço por $\mathrm{m}^{2}$ no período. Entretanto, no mesmo período o VMU se manteve no mesmo patamar, evidenciando que em termos reais os imóveis não apresentaram bruscas variações de preço, mantendo o mesmo nível. 


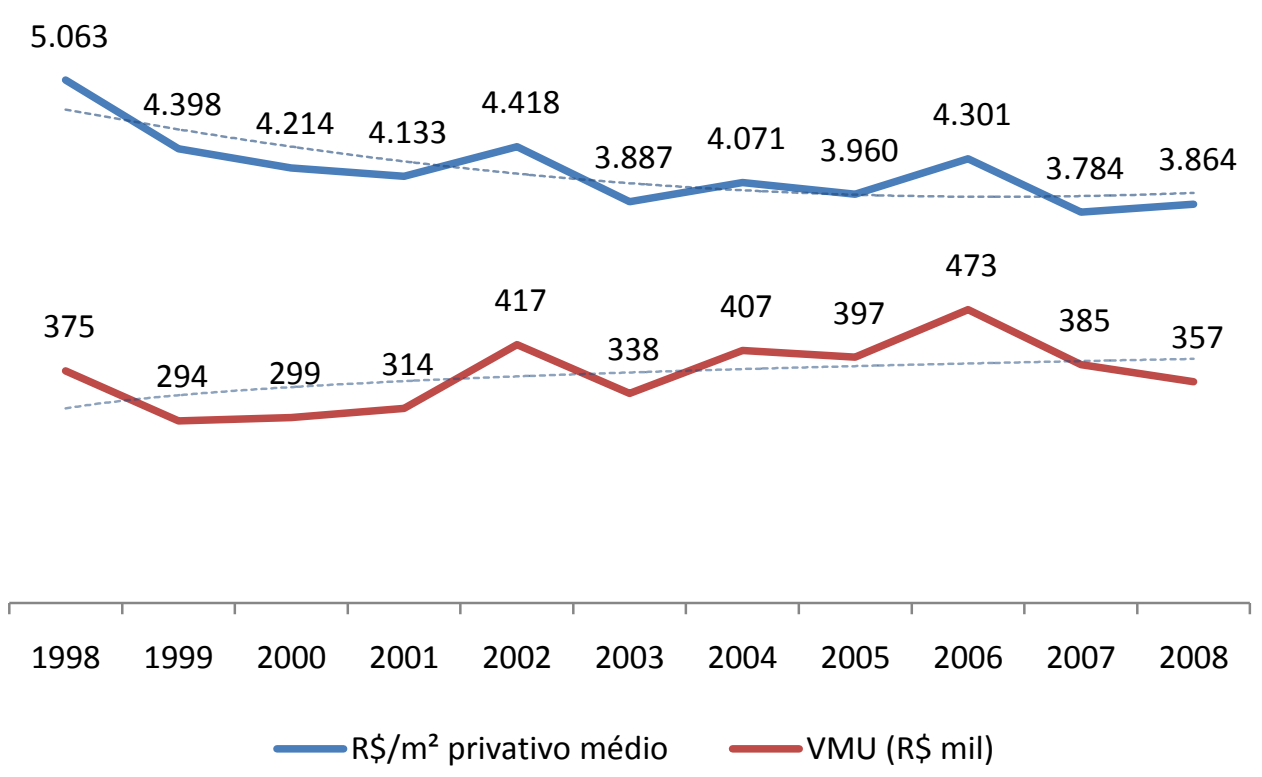

Gráfico 34 - Comportamento da evolução do preço médio por $\mathrm{m}^{2}$ e do VMU das novas unidades habitacionais ofertadas na cidade de São Paulo

Fonte: SECOVI-SP, GEOIMÓVEL, EMBRAESP com adaptações do autor

O gráfico a seguir segrega as ofertas de unidades dentro e fora do limite do SFH. Para unidades acima do limite do $\mathrm{SFH}$, o preço por $\mathrm{m}^{2}$ passou de aproximadamente $\mathrm{R} \$$ 5.500,00 para $\mathrm{R} \$ 4.500,00$ no final do período, o que representa $20 \%$ de decréscimo. Para unidades dentro do SFH esse valor se estabilizou por volta dos R $\mathbf{2 . 8 0 0 , 0 0}$ entre 2003 e 2008 conforme exposto no gráfico a diante. 


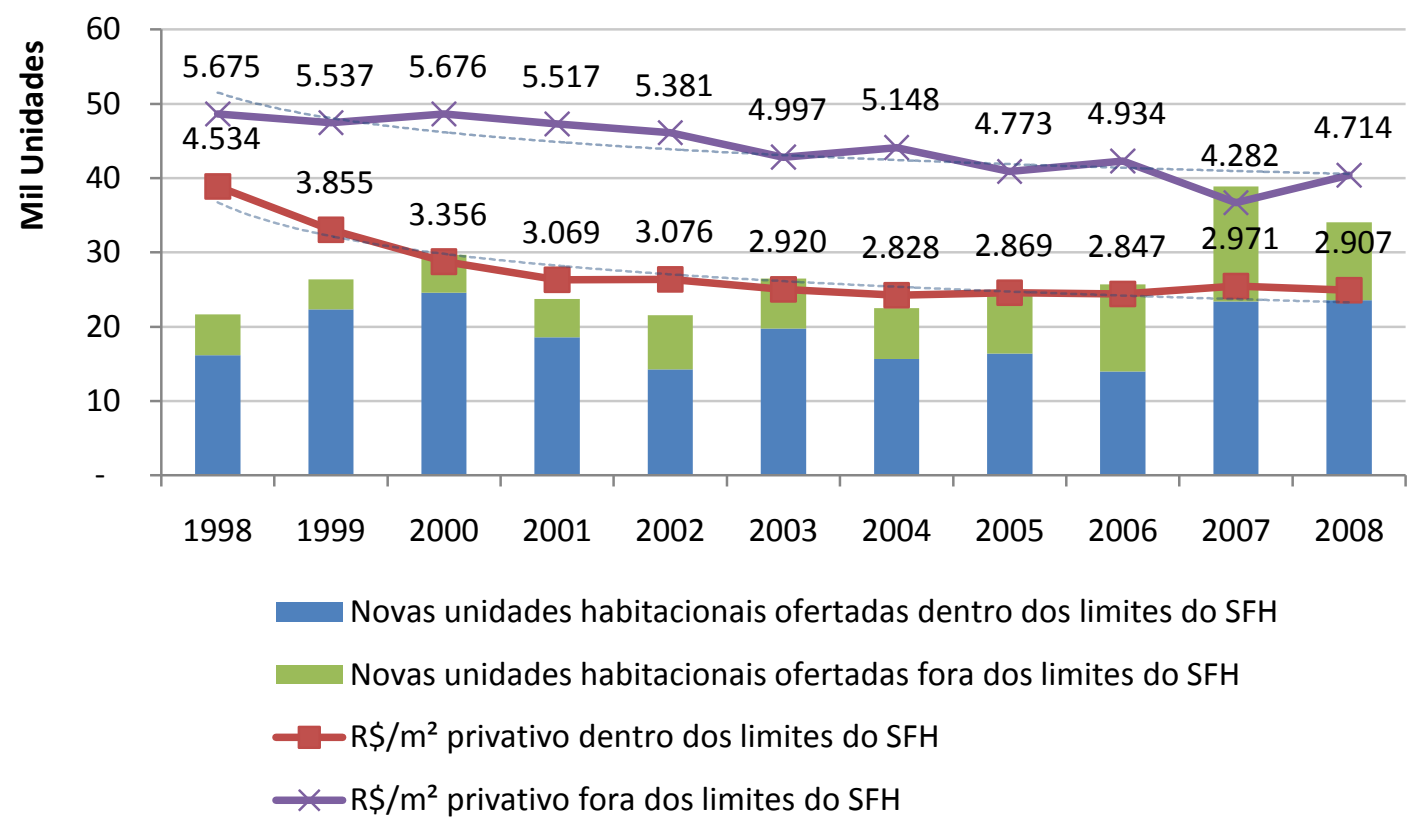

Gráfico 35 - Comportamento da evolução do preço por $\mathrm{m}^{2}$ das unidades lançadas na cidade de São Paulo segundo o público comprador Fonte: SECOVI-SP, GEOIMÓVEL, EMBRAESP com adaptações do autor

Lembrando que os valores apresentados estão expressos em $\mathrm{R} \$$ de 2009 , nota-se que mesmo com a oscilação de produção de unidades no período, os preços mantiveram sua tendência de queda. Em 2007 e 2008, apesar do aumento no número de unidades produzidas o preço das unidades lançadas dentro dos limites do SFH sofreram um incremento, resultado divergente do esperado pelo apresentado na revisão bibliográfica. No entanto, para unidades com valores acima do limite do SFH, mesmo com o incremento na produção, o VMU das unidades lançadas foi reduzido em 2007 e 2008.

Mesmo considerando a limitação da análise do comportamento de apenas 2 anos, pode-se inferir que a maior demanda pela produção de unidades com valor dentro dos limites do SFH contribuiu para sustentar o preço por $\mathrm{m}^{2}$. Enquanto isso, a parcela de unidades acima dos limites do SFH sofreu uma redução no seu preço por $\mathrm{m}^{2}$, o que por sua vez, indica que a demanda não acompanhou a oferta por esse tipo de unidade. 
Uma vez que não foi possível reconhecer uma clara influência do PREÇo na Produção Habitacional Privada, o comportamento dessa variável foi generalizado segundo o esquema apresentado na seqüência. $O$ coeficiente de correlação de Pearson para a variável Preço foi de 0,06 no período considerando as unidades dentro dos limites do SFH, o que demonstra uma correlação fraca positiva. Analisando as unidades fora dos limites do SFH foi encontrado o valor de $\mathrm{r}$ de $-0,9$, o que contradiz as expectativas segundo a revisão bibliográfica realizada. A distorção pode ser causada pelo menor número de unidades ofertadas e pela grande diferença de preços da amostra devido à localização dos empreendimentos voltados para a população de mais alta renda.

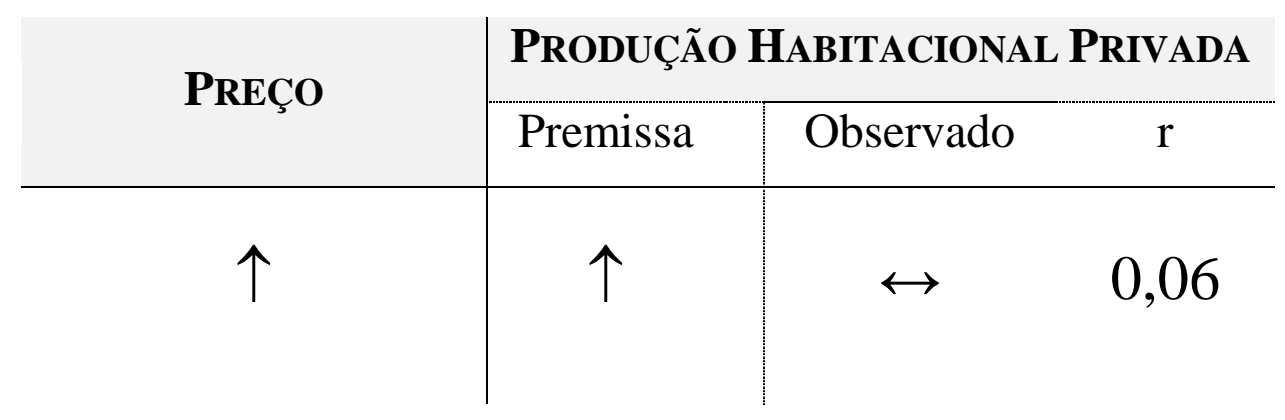

Apesar do valor encontrado contrapor a revisão bibliográfica, seu comportamento pode indicar que a ausência de pressão nos preços foi influenciada pela (i) distribuição geográfica da oferta em regiões menos nobres (ii) economia na cadeia produtiva, possibilitando a manutenção dos padrões de margem pelos agentes produtores e (iii) adequação natural do mercado a capacidade de pagamento dos compradores que até 2005 contavam com condições de financiamento mais restritivas.

\subsection{Renda}

Considerando a estreita relação entre a renda e o nível de emprego, inicialmente será apresentado seu comportamento no período selecionado. 


\subsubsection{Nível de emprego}

Como resultado da atividade industrial no período o nível do emprego formal apresentou uma evolução significativa de $42 \%$. O nível de emprego da população está diretamente relacionado à condição da capacidade de comprometimento de financiamentos de longo prazo, e, portanto, pode ser considerado outro agente exógeno que influencia o comportamento do mercado de produção de unidades habitacionais.

Na cidade de São Paulo, o nível de emprego após apresentar uma retração entre 1999 e 2000 iniciou uma tendência de crescimento até o final do período selecionado. As retrações apresentadas no gráfico a seguir se referem à sazonalidade devido ao trabalho temporário ligado às vendas de natal.

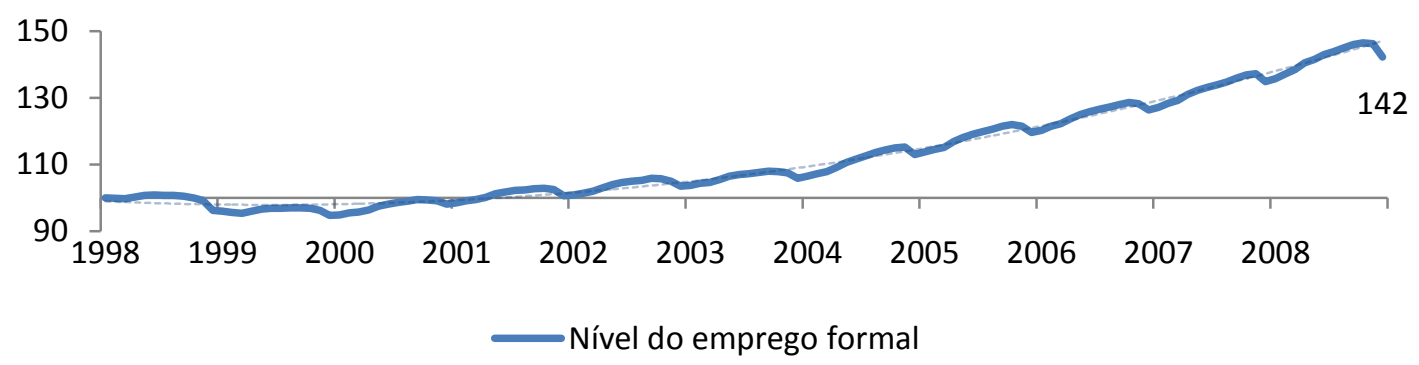

Gráfico 36 - Nível do emprego formal na cidade de SP Fonte: MTE (IBGE)

\subsubsection{População economicamente ativa}

No mesmo período, analisando a população economicamente ativa acima de 15 anos nas regiões metropolitanas do Brasil, nota-se que esta apresentou uma tendência de crescimento desde 1998, o que indica um aumento no desemprego. No entanto, no final do período o nível de pessoas economicamente ativas maiores de 15 anos aumentou aproximadamente $33 \%$ (IBGE) enquanto, conforme mencionado anteriormente, o nível do emprego formal atingiu $42 \%$ de crescimento. 
No gráfico a seguir é possível notar o comportamento da taxa de atividade das pessoas com mais de 15 anos nas regiões metropolitanas. Conforme apresentado no gráfico vale ressaltar que a taxa de ocupação apresentou um comportamento cíclico no período, apresentando picos de baixa nos anos de 1999, 2001 e 2003, nos anos seguintes o índice variou entre 56 e 58.

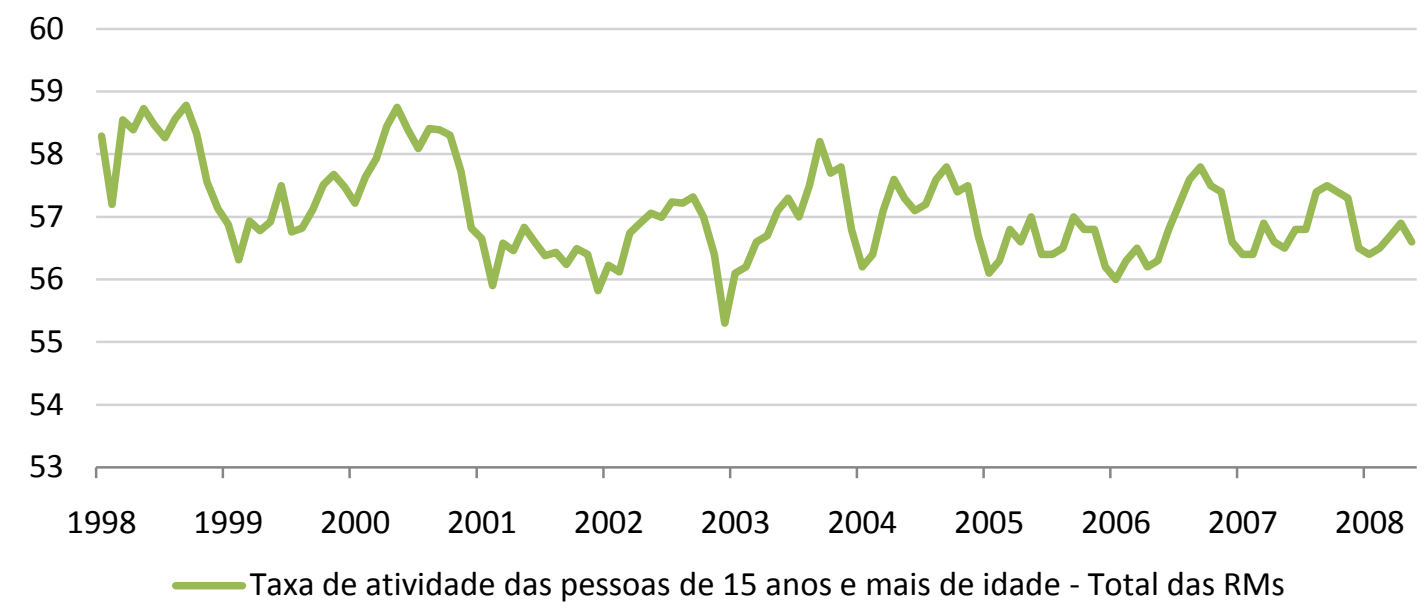

Gráfico 37 - Taxa de atividade da população economicamente ativa nas Regiões Metropolitanas do Brasil

Fonte: IBGE-PME

Analisando o índice de desemprego disponível a partir de 2001 para a RMSP, tem-se que após oscilar até 2004 entre 12\% e 14\%, este iniciou uma tendência decrescente até 2008 refletindo a condição econômica do período.

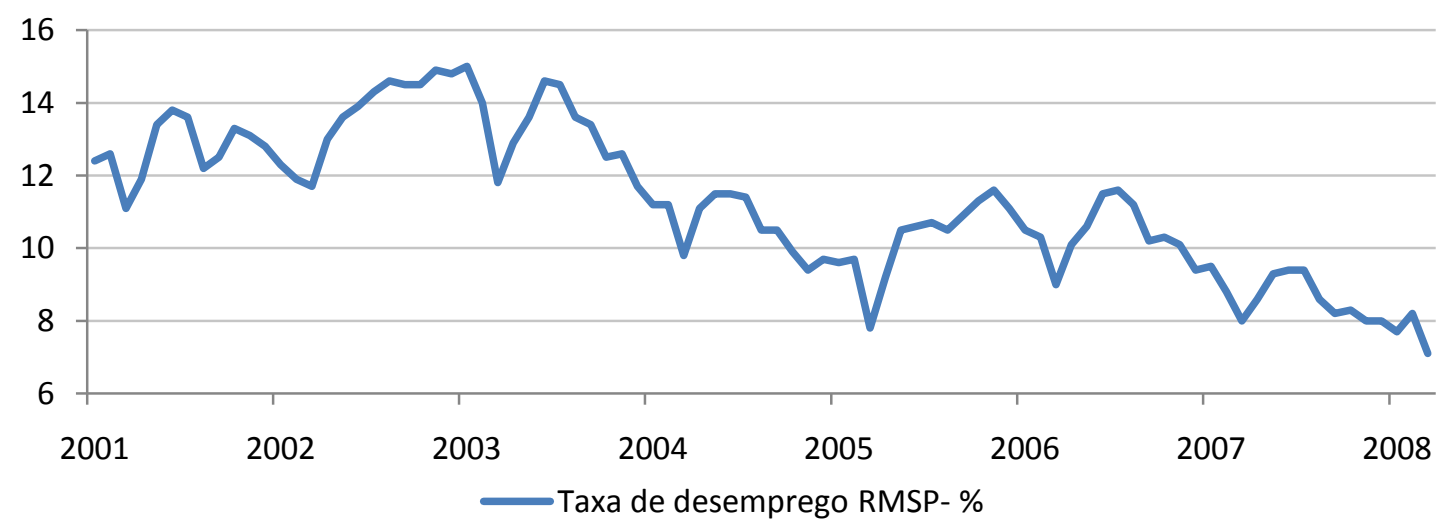

Gráfico 38 - Taxa de desemprego na RMSP

Fonte: IBGE 


\subsubsection{Distribuição de renda}

Analisando a distribuição da população no Brasil, segundo os dados de renda dos domicílios do CENSO realizado pelo IBGE em 2000, tem-se que aproximadamente 17\% dos domicílios, o que representa 8 milhões de residências, tinha renda acima de 10 salários mínimos $(\mathrm{SM})$. A maior concentração dos domicílios brasileiros tem rendimentos até $3 \mathrm{SM}$, somando $45 \%$ da base total.

Segregando os domicílios do Estado de São Paulo, tem-se uma maior parcela de domicílios acima de $10 \mathrm{SM}$, os quais representam aproximadamente $27 \%$ da base do estado ou o equivalente a 2,8 milhões de residências. A base de domicílios com renda até 3 SM também é menor, representando aproximadamente $27 \%$ do total e evidenciando uma maior concentração de renda no Estado.

Mantendo a tendência de concentração de renda, a cidade de São Paulo tem aproximadamente $36 \%$ dos seus domicílios com renda acima de 10 salários mínimos, representando 1,09 milhões de residências. A base de domicílios com renda inferior a 3 salários mínimos é de aproximadamente $21 \%$.

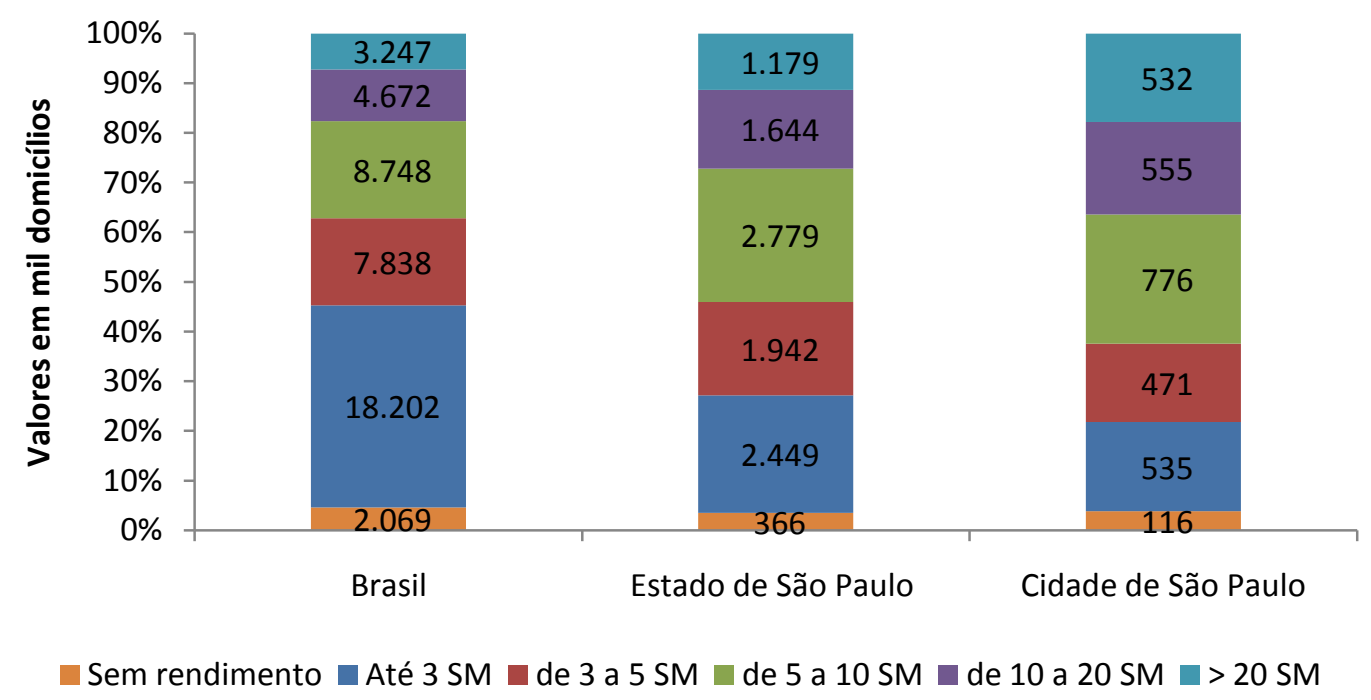

Gráfico 39 - Distribuição da renda dos domicílios em 2000

Fonte: CENSO 2000(IBGE) 


\subsubsection{Evolução da renda média}

Analisando a evolução da renda média mensal domiciliar em R \$ de 2009, nota-se que a média brasileira passou em termos reais de $R \$ 1.458,00$ para $R \$ 1.861,00$, o que representa um incremento de $28 \%$. O Sudeste apresentou no mesmo período um incremento de $16 \%$ e o Estado de São Paulo $7 \%$.

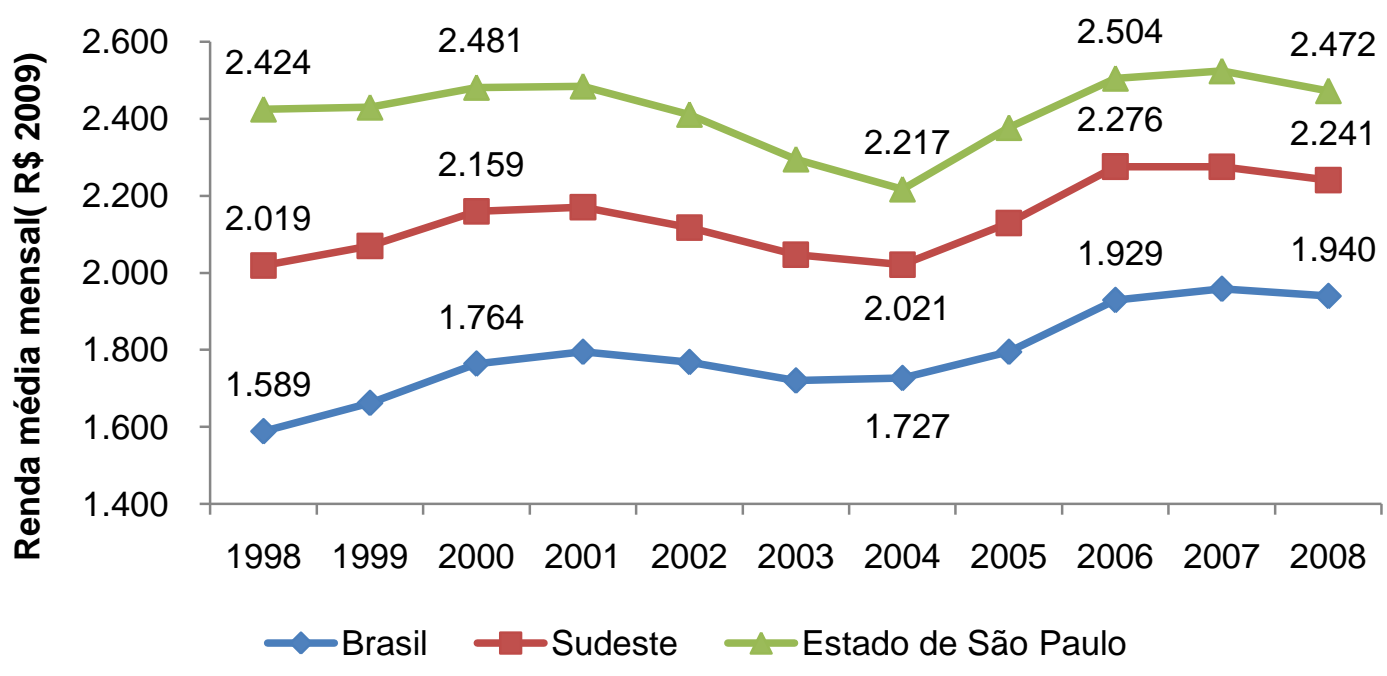

Gráfico 40 - Renda média mensal por domicílio: Brasil x Sudeste x Estado de São Paulo

Fonte: PNAD (IBGE)

A evolução do nível de pessoas empregadas, bem como da renda da população, influenciam diretamente a demanda pela compra de unidades habitacionais visto que estes indicadores são determinantes para demonstrar a capacidade de compra da população. Considerando a renda média domiciliar no período selecionado como resultado da influência das condições econômicas no orçamento dos domicílios, é apresentado a seguir o comportamento relativo da produção de unidades na cidade de São Paulo e da renda média domiciliar no Estado de São Paulo considerando 1998 como número índice 100. Não foi possível ter acesso aos dados de renda desagregados da cidade de São Paulo e por isso não foi respeitado o mesmo universo de análise. No entanto, a comparação é valida para identificar tendências gerais, que, 
conforme apresentado anteriormente na comparação do Brasil, Estado de São Paulo e Região Metropolitana de São Paulo, se mantém.

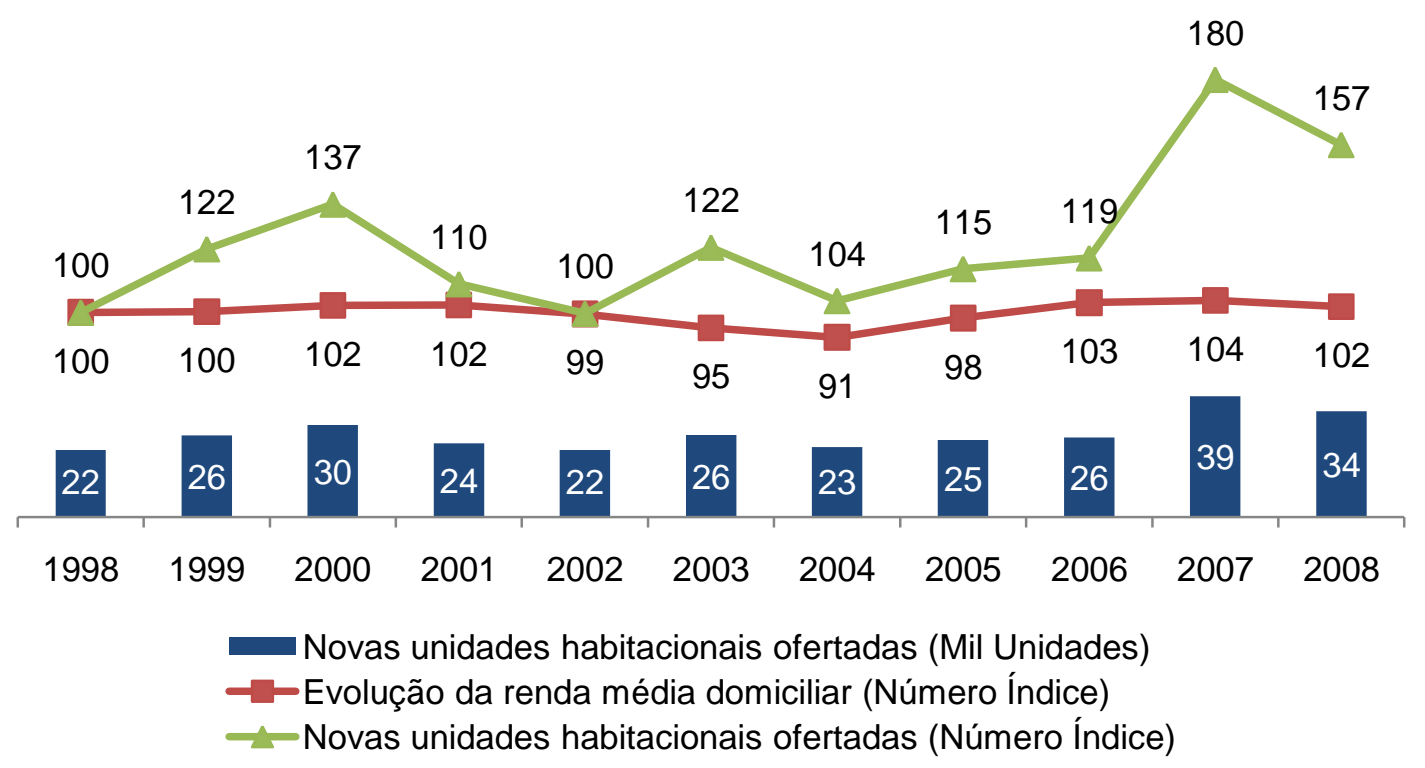

Gráfico 41 - Evolução da Renda média mensal por domicílio no Estado de São Paulo x Novas unidades habitacionais ofertadas na cidade de São Paulo

Fonte: PNAD (IBGE)

Apesar da menor variação da renda média domiciliar, nota-se que a exceção do período entre 2002 e 2004 a produção de unidades acompanhou o comportamento da renda média domiciliar. Esse comportamento está alinhado com o desempenho esperado apresentado na revisão bibliográfica e pode ser explicado pelo modelo de negócio utilizado pelos empreendedores.

Usualmente, os empreendedores iniciam a comercialização dos projetos antes da construção utilizando o desempenho das vendas de seus projetos e dos concorrentes para regular seu nível de atividade. Dessa forma, o aumento da renda ${ }^{19}$ proporciona um incremento nas vendas, que por sua vez é percebida pelos empreendedores que aumentam a oferta.

\footnotetext{
${ }^{19} \mathrm{O}$ impacto do aumento da renda proporciona uma maior capacidade de comprometimento pelos compradores, facilitando a obtenção dos financiamentos habitacionais e aumentando a atividade do mercado.
} 
O coeficiente de correlação Pearson (r) da variável RENDA e produção habitacional privada foi de 0,50 no período, representando uma correlação positiva moderada. $\mathrm{O}$ comportamento dessa variável é reproduzido no esquema a seguir.

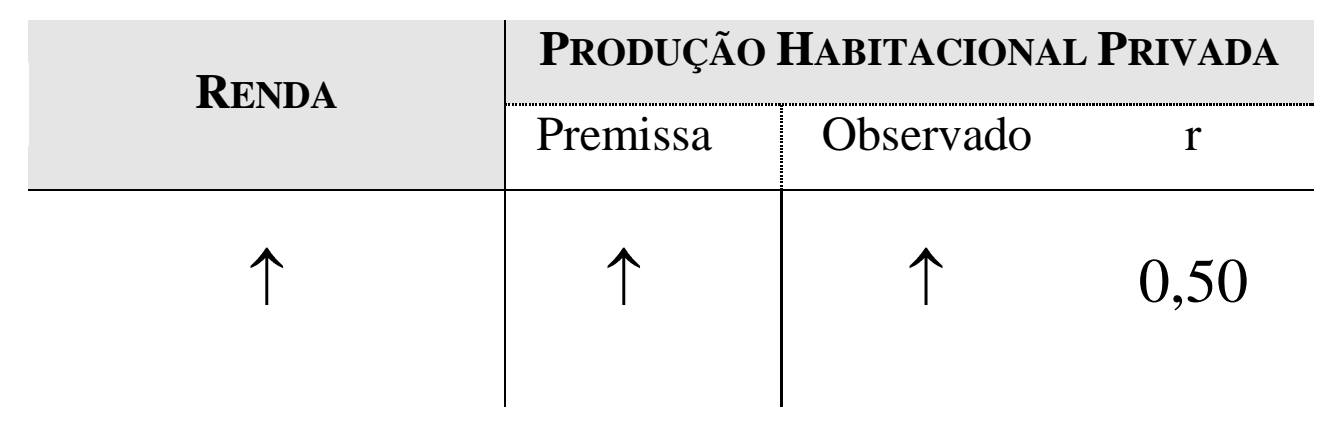

6.3. Taxa de atratividade setorial

De acordo com o conceito de TAXA DE ATRATIVIDADE, tem-se que esta varia em função do custo de oportunidade dos investimentos acrescido de um prêmio de acordo com o padrão de risco envolvido no negócio. Admitindo que não é possível capturar o prêmio de cada agente produtor do mercado uma vez que estes variam de acordo com a sua percepção de risco e retorno, esta análise será realizada a partir da observação da oscilação da rentabilidade mínima da economia.

No caso brasileiro, a remuneração dos títulos do tesouro nacional se figura como o padrão de rentabilidade mínima esperada por investidores. Dessa forma, a TAXA DE ATRATIVIDADE oscilara em função da taxa SELIC e o seu comportamento no período é apresentado no próximo gráfico. Os dados estão expressos como percentual equivalente ao ano com base em 252 dias de acordo com o BACEN. 


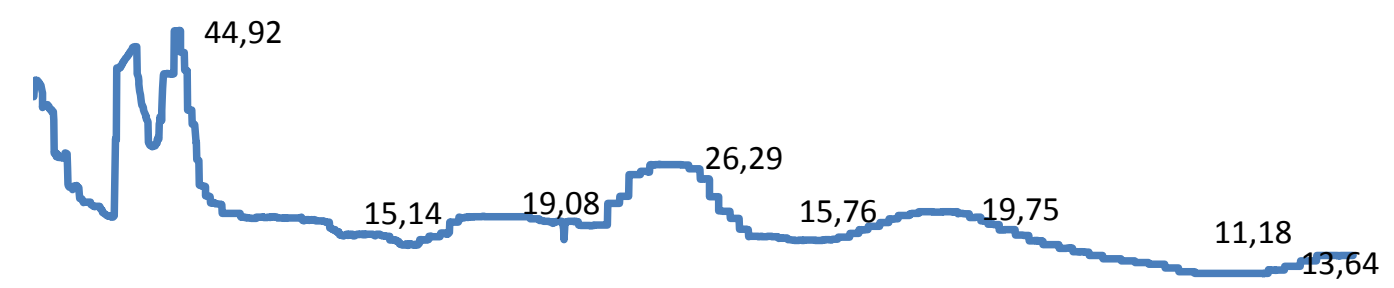

$\begin{array}{lllllllllll}1998 & 1999 & 2000 & 2001 & 2002 & 2003 & 2004 & 2005 & 2006 & 2007 & 2008\end{array}$

Taxa de juros - Selic anualizada base 252 - \% a.a.

Gráfico 42 - Evolução da taxa SELIC (\% equivalente ao ano)

Fonte: Sisbacen

De acordo com o gráfico é possível notar que até o primeiro semestre de 1999 a taxa SELIC apresentou uma forte flutuação atingindo rentabilidade de $45 \%$ equivalente ao ano. Neste período pode-se destacar o impacto da crise da Rússia no ambiente econômico mundial e a reeleição do Governo Fernando Henrique Cardoso. Este cenário causou uma grande distorção na economia impactando todos o setor produtivo.

É importante ressaltar que a taxa SELIC é um importante instrumento de Política monetária do governo no controle da inflação e altera sua meta de acordo com as expectativas do Comitê da Política Monetária $(\mathrm{COPOM})^{20}$. A evolução da inflação segundo o índice ICPA é apresentada no gráfico a diante, onde pode ser observada a pressão inflacionária no ano de 2002, combatida com o aumento da Selic durante o ano de 2003 e a repetição da mesma estratégia no ano de 2008.

\footnotetext{
${ }^{20}$ A periodicidade da reunião do COPOM se alternou no período em um intervalo de 30 a 45 dias.
} 


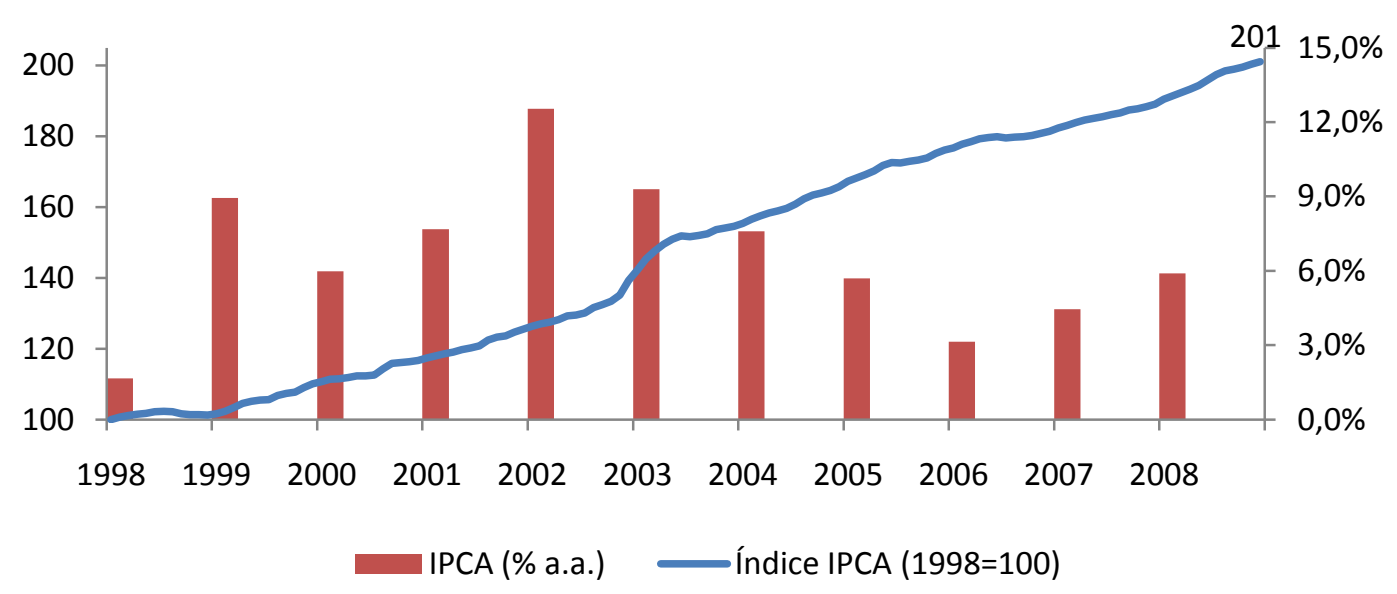

Gráfico 43 - Evolução do índice de Inflação IPCA

Fonte: IBGE

No período após 1999, observa-se que a taxa oscilou entre $15 \%$ e $20 \%$ equivalente ao ano. Em 2001 há uma nova tendência de alta passando de 15\% ao ano para $19 \%$ ao ano, influenciada principalmente pela queda da bolsa americana de tecnologia Nasdaq. Em 2003 ocorre uma nova alta, onde o índice alcançou 26\% equivalente ao ano, resultado do período pré-eleição do governo Lula e a guerra do Iraque. Após retornar ao patamar de 15\% equivalente ao ano em 2004, em 2005 o índice retoma a escalada para próximo dos $20 \%$, buscando conter a subida da inflação no período.

Após o segundo semestre de 2005 é iniciada uma redução gradativa, que em 2008 chega ao menor patamar do período de aproximadamente $11 \%$ equivalente ao ano. Mais uma vez, temendo um descontrole inflacionário o COPOM retoma a subida do índice que termina 2008 em aproximadamente $13,75 \%$.

Conforme mencionado anteriormente, os juros cobrados no SFH, principal fonte de recurso responsável pelo FINANCIAMENTO HABITACIONAL no período, foram limitados a $12 \%$ a.a. no período. Portanto, mesmo quando a TAXA DE ATRATIVIDADE atingiu valores acima de $40 \%$ a.a. os CUSTOS DO FinANCIAMENTO HABITACIONAL não acompanharam seu incremento, no entanto, é evidente seu impacto na OFERTA DE RECURSOS, que após 2006, com a SELIC no seu menor patamar do período, teve um incremento significativo. 
Seguindo essa premissa, pode-se destacar a dificuldade de atração de novos recursos para o setor habitacional até 2006, visto que, sem subsídios, as operações com recursos do SBPE e do FGTS também não se viabilizariam. O comportamento da Selic também contribui para explicar o reduzido volume de operações no mercado de capitais envolvendo CRIs, os quais somente podiam oferecer aos investidores uma rentabilidade inferior a taxa de atratividade mínima da economia no período.

Além de influenciar o mercado de crédito, a SELIC também exerce influência na atividade produtiva. Assumindo que as atividades da produção habitacional privada apresentam um risco superior ao custo de oportunidade, as operações neste mercado deveriam oferecer prêmios acima dos apresentados nos gráficos anteriores.

Buscando identificar a influência da TAXA DE ATRATIVIDADE na PRODUÇÃO HABITACIONAL PRIVADA, o gráfico a seguir apresenta a flutuação da taxa de juros SELIC, expressa como percentual equivalente ao ano com base em 252 dias de acordo os dados do BACEN comparada às novas unidades ofertadas na cidade de São Paulo.

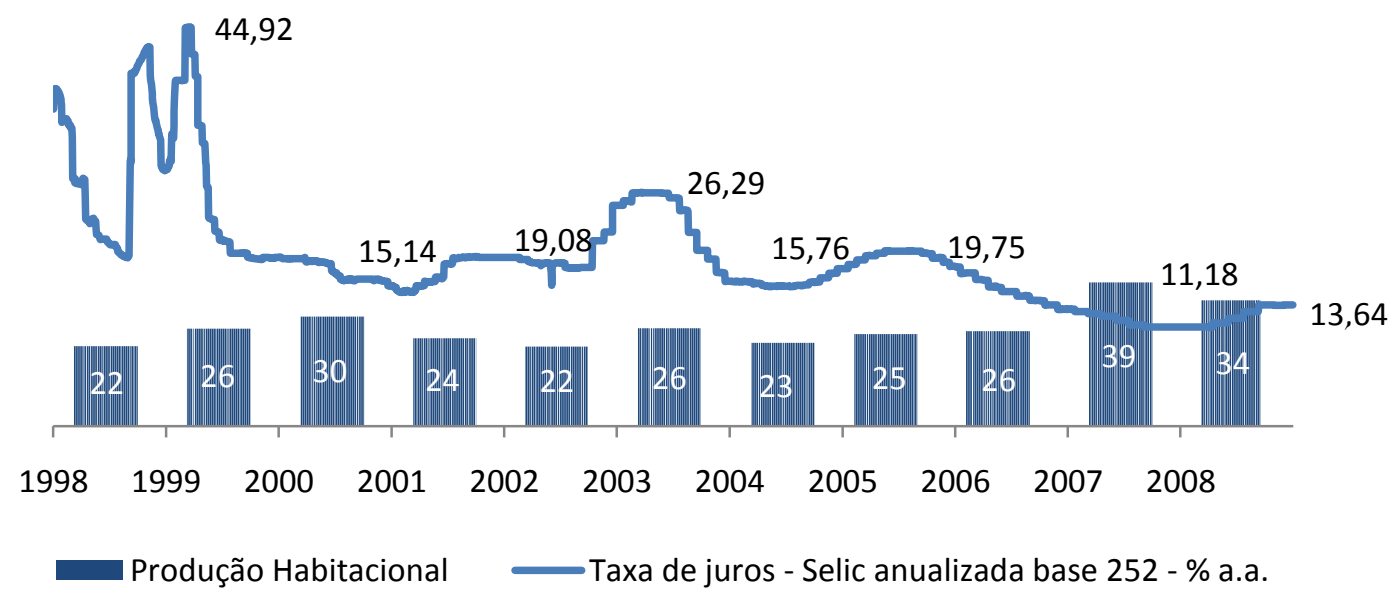

Gráfico 44 - Evolução da taxa de juros Selic (\% equivalente ao ano) frente à Produção Habitacional

Fonte: Sisbacen 
Apesar da grande variação da SELIC no período, a PRODUÇÃo HABITACIONAL PRIVADA se manteve entre 22 e 30 mil anuais, até 2006. O incremento da produção a partir de 2007 coincidiu com o menor patamar do período que conforme mencionado anteriormente contribuiu para o aumento da OFERTA DE RECURSOS criando assim um ciclo virtuoso para a produção habitacional.

O coeficiente de correlação de Pearson (r) foi de $-0,32$, demonstrando uma correlação negativa moderada e o comportamento da variável taxa de atratividade pode ser generalizado conforme o esquema a seguir.

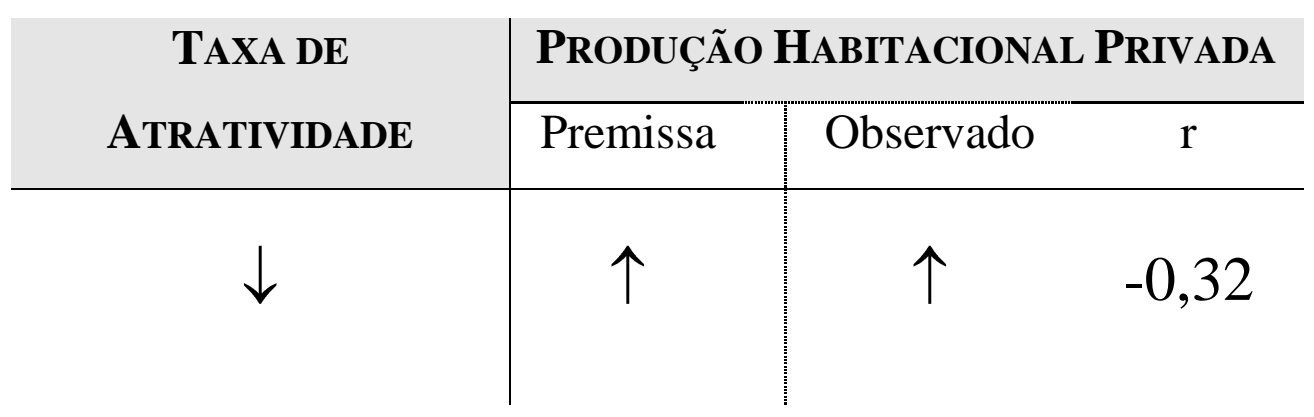

6.4. Comportamento de outros indicadores no período selecionado

Além das variáveis apresentadas até o momento, outros indicadores são comumente utilizados para relacionar a produção habitacional com o comportamento da economia nacional em geral. Dentre elas está o Produto Interno Bruto e o Índice de Confiança da Indústria os quais são apresentados em detalhes a seguir.

\subsubsection{Produto Interno Bruto (PIB)}

Analisando o desempenho do PIB brasileiro em moeda de 2008, excetuando assim o efeito da inflação, tem-se o desempenho apresentado no gráfico a seguir que considerou o volume de 1998 como índice 100. 


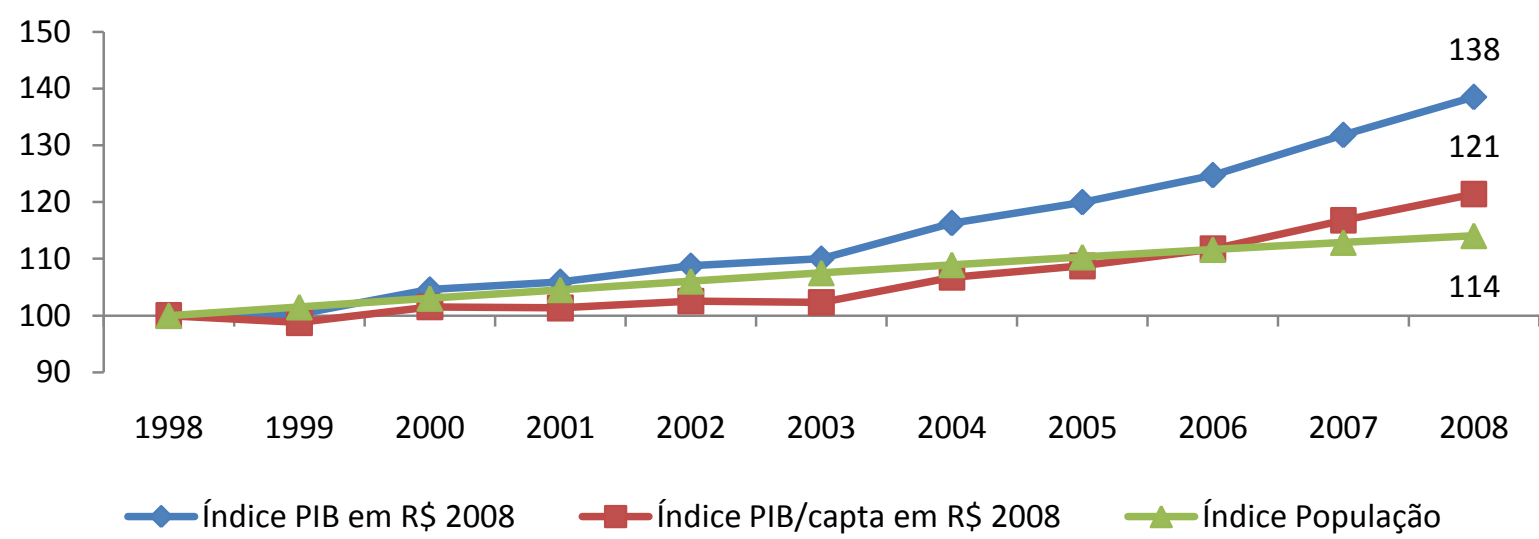

Gráfico 45 - PIB x PIB per capta x População no Brasil

Fonte: IBGE, BACEN

De acordo com os dados apresentados, é possível verificar que o Brasil experimentou um crescimento ao longo de todo o período, sendo que a partir de 2003 este se deu de forma mais acentuada, terminando 2008 40\% acima do nível de 1998. No mesmo período o incremento da população se manteve constante, chegando ao final de 2008 aproximadamente 14\% maior. Analisando o PIB per capta, apenas em 1999 houve uma retração, mantendo o mesmo patamar até 2003. A partir de 2003 esse indicador aumentou sua tendência de crescimento terminando o período $21 \%$ maior.

Analisando o Estado de São Paulo, nota-se que a mesma tendência nacional foi reproduzida. No entanto, o estado experimentou uma maior retração com o índice atingindo valores inferiores a 100 nos anos de 2002 e 2003, recuperando sua tendência de crescimento a partir de então. No entanto, o PIB e o PIB per capta do Estado de São Paulo alcançaram um índice aproximadamente 5 pontos inferior ao nacional em 2006 conforme apresentado no gráfico a seguir. 


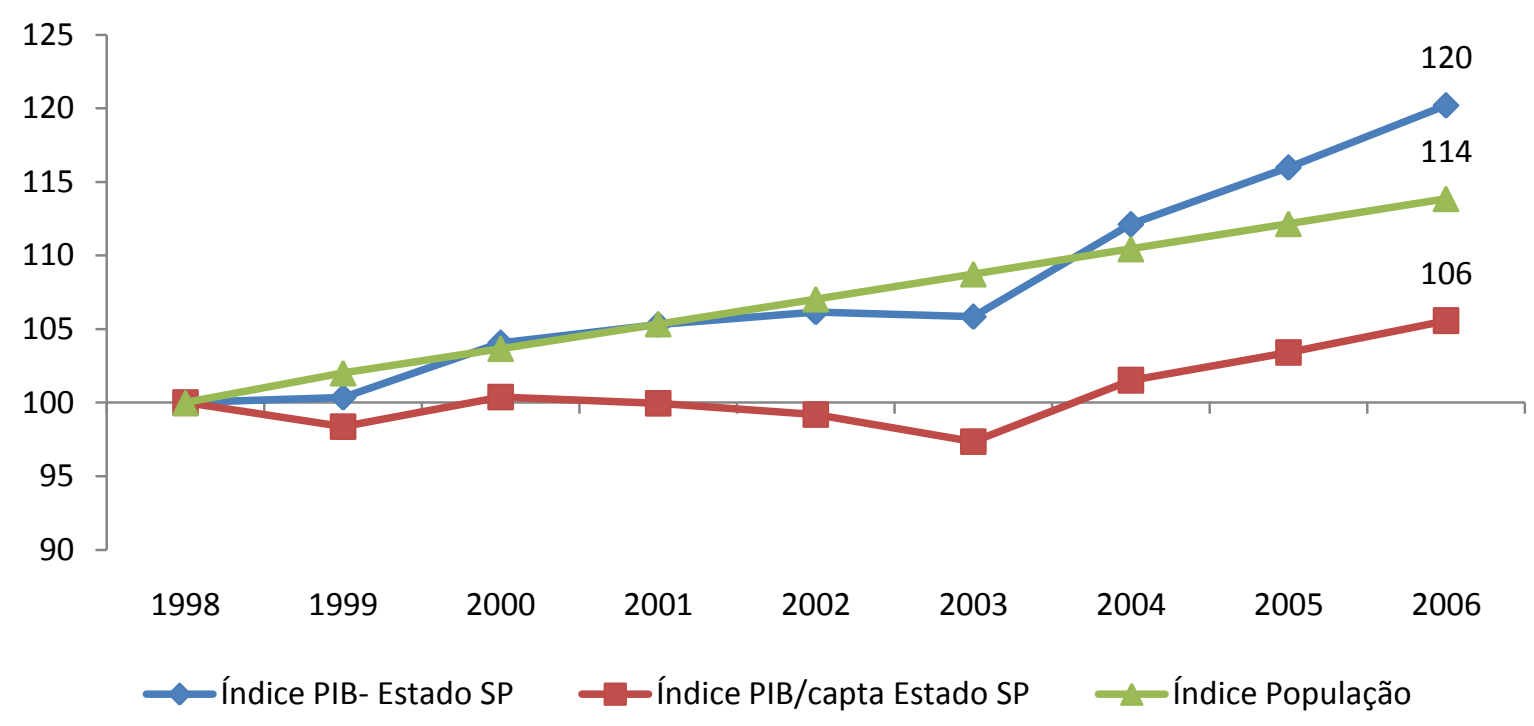

Gráfico 46 - PIB x PIB per capta Estado de SP

Fonte: IBGE, BACEN

A análise do indicador PIB traz informações quanto à quantidade de riqueza produzida na economia. Ao compará-lo com a atividade de uma cadeia produtiva específica é possível identificar o quanto ela se beneficiou e contribuiu para a geração de riqueza. 
No gráfico a diante é apresentado o comportamento relativo do crescimento do PIB nacional e da Produção Habitacional Privada na cidade de São Paulo.

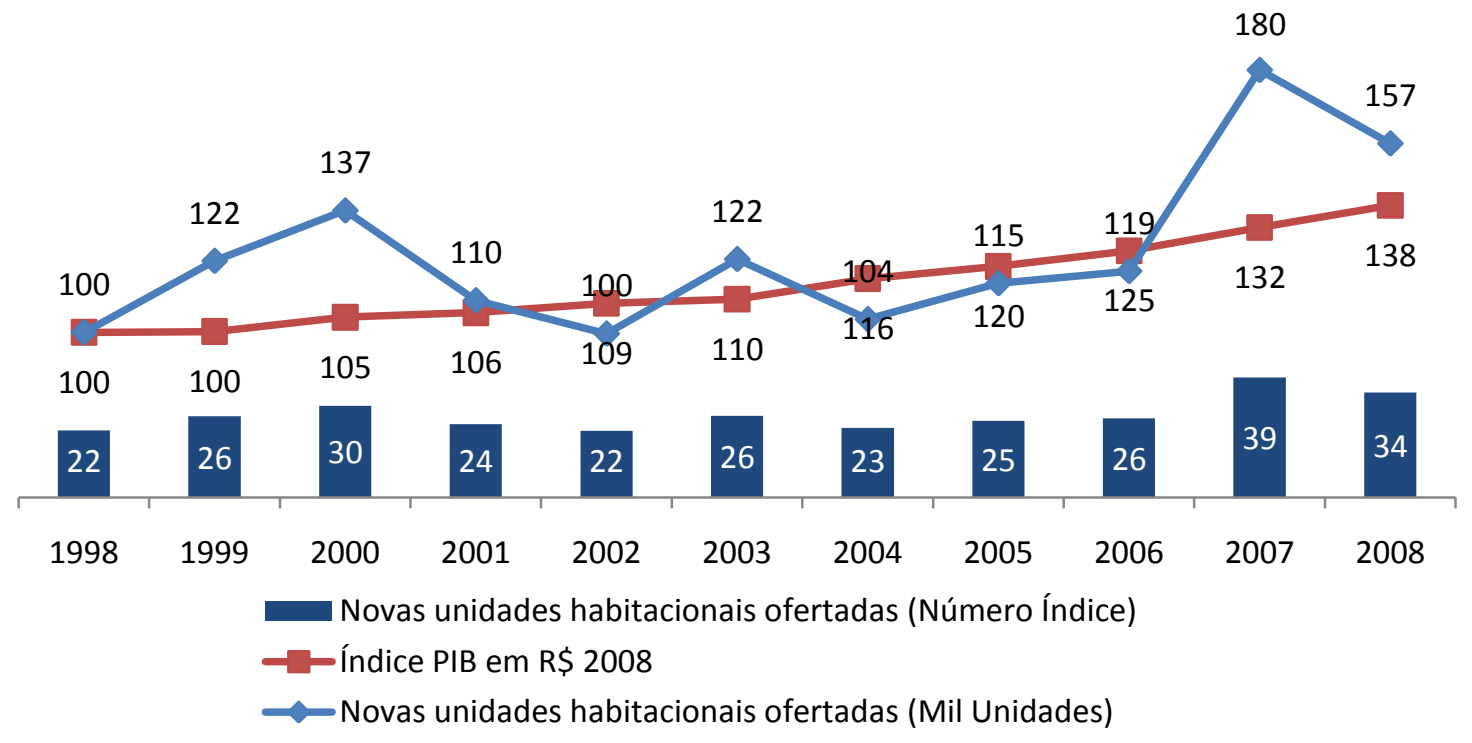

Gráfico 47 - PIB x Novas unidades habitacionais ofertadas na cidade de São Paulo Fonte: IBGE, BACEN

Nota-se que a produção de unidades oscila no período selecionado, diferentemente do crescimento constante do PIB, porém mantendo a mesma tendência de crescimento. O comportamento é generalizado no esquema a seguir e o coeficiente de correlação Pearson (r) é de 0,67, evidenciando uma correlação positiva moderada.

\begin{tabular}{c|c|cc}
\multirow{2}{*}{ PIB } & \multicolumn{3}{|c}{ Produção Habitacional Privada } \\
\cline { 2 - 3 } & Premissa & Observado & r \\
\hline$\uparrow$ & - & $\uparrow$ & 0,67 \\
\end{tabular}




\subsection{2. Índice de confiança da Indústria}

Outro indicador que ilustra a condição econômica no período e o nível de atividade dos agentes econômicos é o Índice de confiança da indústria divulgado pela FGV. O índice é composto pela sondagem do nível de confiança dos setores de Bens de Consumo, Bens de Capital, Material para Construção e Bens Intermediários.

De acordo com o gráfico a seguir é possível notar que em 1999 este índice apresentou o menor patamar do período, conforme exposto anteriormente pela crise da Rússia. Após uma recuperação no ano subseqüente, no final do ano 2000, após a queda da bolsa americana de tecnologia Nasdaq é iniciada uma nova tendência de queda que se inverte somente após o atentado de 11 de Setembro de 2001.

Após oscilar no mesmo patamar até o segundo semestre de 2003, ocorre mais uma baixa histórica devido principalmente as incertezas geradas no período pré eleitoral do governo Lula. A partir de 2004, após um curto período entre 2005 e 2006, o índice permanece acima de 100 pontos pelo maior prazo consecutivo. No segundo semestre de 2008, devido à crise financeira mundial e o subseqüente pedido de falência do banco Lehman Brothers, o índice apresenta sua maior queda histórica rompendo novamente a barreira dos 100 pontos.

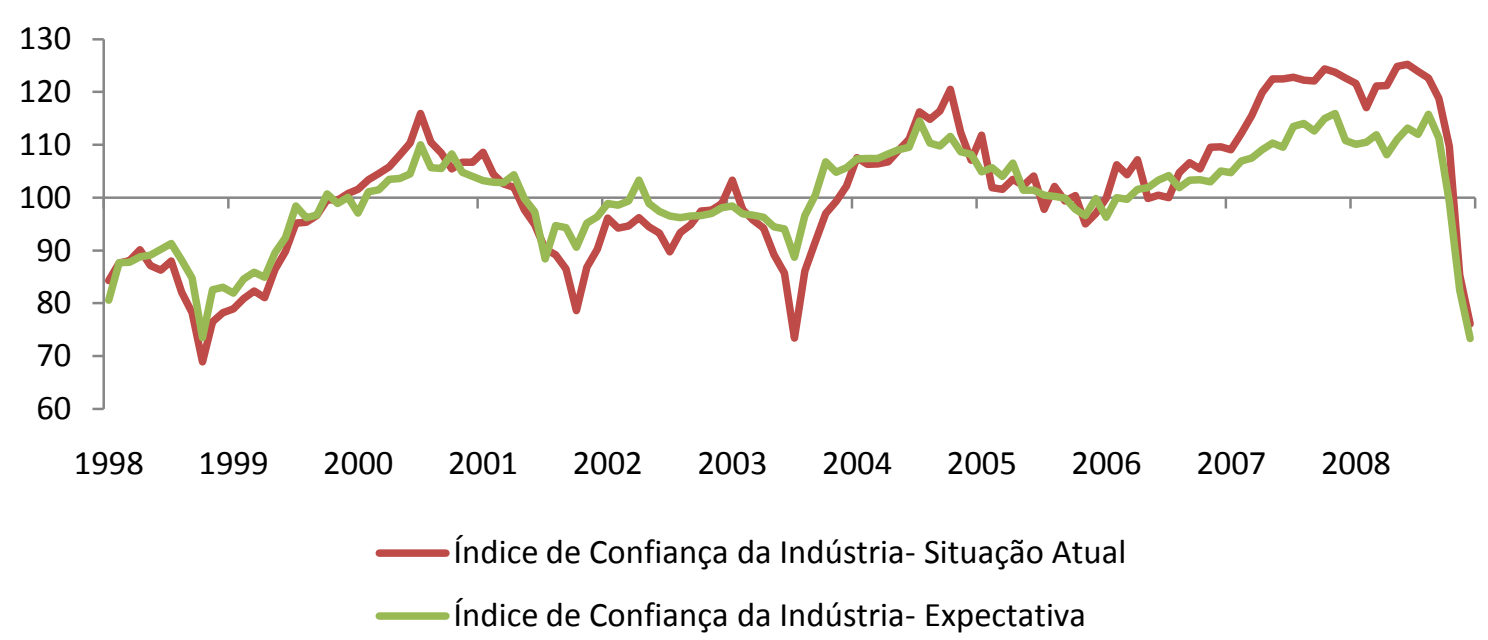

Gráfico 48 - Índice de confiança da indústria

Fonte: FGV 
No mercado de empreendimentos habitacionais, os agentes produtores programam o lançamento de seus projetos de acordo com a expectativa do comportamento econômico em um horizonte de 36 meses $^{21}$. Dessa forma, o volume produzido pelos empreendedores representa sua leitura do ambiente econômico para os próximos anos. Com o objetivo de comparar as expectativas dos empreendedores habitacionais com os agentes da indústria, no gráfico a diante é exposta a comparação da evolução em número índice de unidades produzidas e do Índice de Confiança da Indústria.

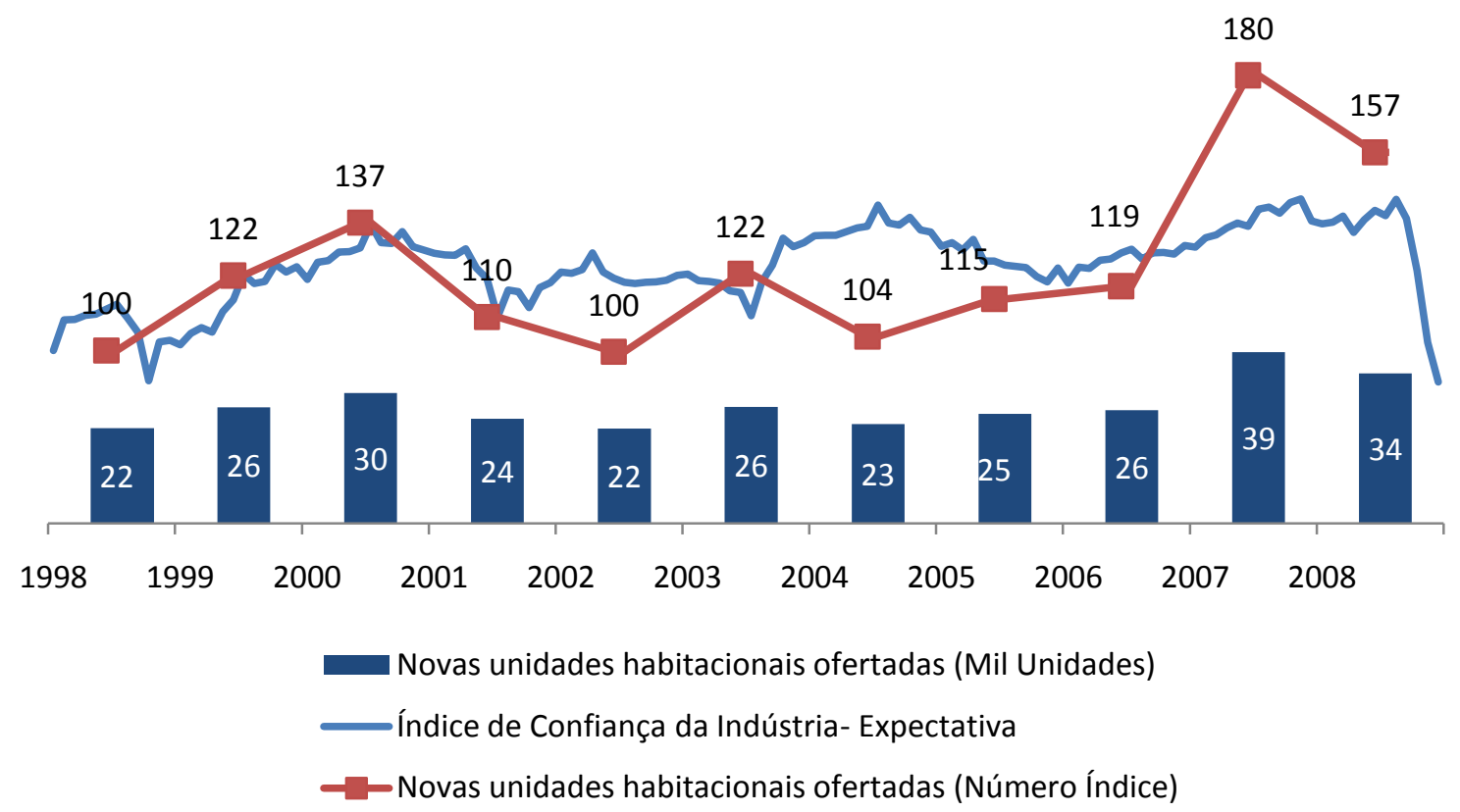

Gráfico 49 - Índice de confiança da indústria x Novas unidades habitacionais ofertadas na cidade de São Paulo

Fonte: FGV

Nota-se que a expectativa dos agentes foi semelhante no período a exceção do ano de 2002 e 2004, onde a indústria apresentou uma ligeira retração. Os anos de 2007 e 2008 também demonstraram um descolamento representativo que pode ser explicado pela quantidade de recursos que o setor teve acesso e que antes estavam indisponíveis. No entanto, de forma geral, houve o acompanhamento da PRODUÇão HABITACIONAL de acordo com o ÍNDICE DE CONFIANÇA.

\footnotetext{
${ }^{21} \mathrm{O}$ ciclo de um empreendimento habitacional tem um ciclo de aproximadamente 36 meses entre aquisição do terreno, planejamento do produto, lançamento e construção.
} 
O coeficiente de correlação Person para as variáveis ÍNDICE DE CONFIANÇA e Produção Habitacional PRIVAda entre 1998 e 2008 foi de 0,58, o que representa uma correlação positiva moderada e está apresentada de forma esquemática abaixo.

\begin{tabular}{|c|c|c|c|}
\hline \multirow{3}{*}{$\begin{array}{c}\text { ÍNDICE DE } \\
\text { CONFIANÇA DA } \\
\text { INDÚSTRIA }\end{array}$} & \multicolumn{3}{|c|}{ Produção Habitacional Privada } \\
\hline & & & $\mathrm{r}$ \\
\hline & Premissa & Observado & \\
\hline$\uparrow$ & - & $\uparrow$ & 0,58 \\
\hline
\end{tabular}




\section{CONCLUSÕES}

Conforme esperado, o comportamento do mercado de ProdUÇão HABITACIONAL PRIVADA da cidade de São Paulo no período entre 1998 e 2008 não acompanhou a dinâmica dos modelos apresentados na revisão bibliográfica.

\subsection{Resumo do comportamento das variáveis}

A seguir será resumida a premissa de comportamento preconizado e o observado na pesquisa realizada.

\begin{tabular}{|c|c|c|c|}
\hline \multirow[t]{2}{*}{$\begin{array}{c}\text { VARIÁvel CONDICIONANTE } \\
\text { estudada }\end{array}$} & \multicolumn{3}{|c|}{$\begin{array}{l}\text { PRODUÇÃo HABITACIONAL PRIVADA } \\
\text { (Impacto a partir do incremento da variável } \\
\text { estudada) }\end{array}$} \\
\hline & Premissa & Observado & $\mathrm{r}$ \\
\hline FORMAÇÃO DE DOMICÍLIOS & $\uparrow$ & $\begin{array}{c}\leftrightarrow \\
\text { (fraca positiva) }\end{array}$ & 0.04 \\
\hline OFERTA DE RECURSOS & $\uparrow$ & $\begin{array}{c}\uparrow \\
\text { (forte positiva) }\end{array}$ & 0.73 \\
\hline $\begin{array}{c}\text { CUSTOS DO FINANCIAMENTO } \\
\text { HABITACIONAL }\end{array}$ & $\downarrow$ & $\begin{array}{c}\downarrow \\
\text { (moderada negativa) }\end{array}$ & $(0.66)$ \\
\hline Preço & $\uparrow$ & $\begin{array}{c}\leftrightarrow \\
\text { (fraca positiva) }\end{array}$ & 0.06 \\
\hline RENDA & $\uparrow$ & $\begin{array}{c}\uparrow \\
\text { (moderada positiva) }\end{array}$ & 0.50 \\
\hline TAXA DE ATRATIVIDADE & $\downarrow$ & $\begin{array}{c}\downarrow \\
\text { (moderada negativa) }\end{array}$ & $(0.32)$ \\
\hline
\end{tabular}

Pode-se destacar entre os movimentos observados o descolamento entre a formação de domicílios e a Produção Habitacional Privada entre 2001 e 2006, evidenciando que outros fatores restringiram o nível de atividade dos agentes produtores do mercado de empreendimentos habitacionais. Esta variável apresentou o menor valor de r, o que comprova a fraca correlação entre a PRODUÇão HABITACIONAL PRIVADA e a FORMAÇÃO DE DOMICÍlIOS no período. 
7.2. O impacto da Oferta de Recursos no período selecionado

Seguindo o objetivo do trabalho, pode-se sustentar como a principal causa do descolamento o comportamento da variável OFERTA DE RECURSOS no período, a qual apresentou o maior coeficiente de correlação de Pearson $(+0,73)$ entre todos os movimentos estudados. O impacto desta variável pode ser dividido da seguinte forma:

\subsubsection{Direcionamento dos recursos do SFH}

A maior fonte de recursos para o setor continua sendo o SFH implementado na década de 60, o que torna os agentes produtores extremamente dependentes deste sistema. Conforme apresentado nos capítulos anteriores, a limitação da OFERTA DE RECURSOS influenciou negativamente a PRODUÇão HABITACIONAL PRIVADA.

Os agentes financeiros, no início do período estudado, consumiram o limite de exigibilidade para aplicação do saldo do SBPE em créditos do FCVS, reduzindo assim os recursos aplicados no financiamento habitacional.

Este impacto pode ser claramente observado a partir de 2002 com o crescimento do patamar de unidades ofertadas acompanhando a retomada do direcionamento do saldo do SBPE para o financiamento habitacional.

\subsubsection{Acesso ao mercado de capitais}

A criação em 1997 do SFI que instituiu as condições para possibilitar o desenvolvimento do mercado secundário, e conseqüentemente tornar os investimentos no setor atrativos ao mercado de capitais, ainda não atingiu a maturidade necessária para atrair volumes compatíveis com a necessidade e o potencial da indústria. 
Uma amostra deste potencial pode ser observada no comportamento da produção de unidades pelas empresas que realizaram OPA e que impulsionaram a produção de unidades a partir de 2006 enquanto as demais empresas mantiveram o seu patamar de produção.

As primeiras OPAs, realizadas após 2006, foram responsáveis por injetar recursos nas empresas que levaram a PRODUÇÃo HABITACIONAL PRIVADA a outro patamar. O acesso aos recursos do mercado de capitais aumentou a capacidade produtiva dos empreendedores, possibilitando que estes se aproximassem da demanda por domicílios gerada na cidade de São Paulo. Considerando que as empresas que não realizaram OPA também tiveram acesso aos recursos do SFH e não aumentaram sua capacidade produtiva, pode-se sustentar que a produção habitacional exige recursos complementares aqueles oferecidos pelo sistema oficial atual.

Parte desta necessidade é função do modelo de negócio da PRODUÇÃo HABITACIONAL PRIVADA que exige capital de forma intensiva durante um longo ciclo. Considerando que os empreendedores têm de fazer frente aos custos de terreno, marketing e dos primeiros meses da construção, sem recursos adicionais aos do SFH as empresas não conseguem mudar seu patamar operacional, necessitando do retorno dos investimentos de um ciclo para iniciar o próximo. Por outro lado, aqueles empreendedores que realizaram OPA puderam direcionar os recursos levantados no mercado de capitais para iniciar uma quantidade maior de empreendimentos, alcançando assim um novo patamar operacional que resultou no incremento da oferta de unidades na cidade de São Paulo.

7.2.3. A necessidade de novos recursos para o desenvolvimento do setor

Conforme observado, no período estudado, o fator restritivo da PRODUÇão HABITACIONAL PRIVADA na cidade de São Paulo não foi a variável demanda e sim a OFERTA DE RECURSOS. Dessa forma, a OFERTA DE RECURSOS figurou como a variável 
responsável por limitar os movimentos da PRODUÇÃo Habitacional PRIVADA, restringindo os empreendedores à parcela da demanda que estes poderiam suprir com recursos próprios e do SFH no período. Com a mudança do panorama econômico esta variável se tornou o catalisador do processo, apoiada pelo SFH e pelo mercado de capitais que abasteceu o setor com instrumentos de dívidas e com investimento direto.

A partir dessa observação, deve-se ressaltar a importância da atração de novos recursos para o setor para que a oferta possa acompanhar a demanda, principalmente por meio do mercado de capitais. A atração de novos recursos tende a se apoiar nos modelos de países desenvolvidos onde o mercado secundário facilitou o acesso ao mercado de capitais. Um exemplo de acesso a novos recursos pode vir da venda para investidores de CRIs lastreados em contratos de financiamentos habitacionais como alternativa a utilização dos recursos do SBPE para o mesmo fim. Como apresentado anteriormente, esta modalidade ainda é incipiente e pode se tornar um limitador para a manutenção do crescimento do setor.

Além disso, a necessidade intensiva de capital no modelo de negócio da PRODUÇÃo HABITACIONAL PRIVADA indica que, devido ao desenho do SFH, os recursos do SBPE não são suficientes para suportar a necessidade de investimento dos empreendedores.

Dessa forma, é possível notar que a PRODUÇÃo HABITACIONAL PRIVADA está limitada por uma estrutura de capital apoiada em recursos próprios. No período analisado foi possível avaliar este comportamento observando as empresas que aumentaram sua base de capital por meio de OPAs, as quais descolaram daquelas que se apoiaram predominantemente nos recursos do $\mathrm{SFH}$.

\subsection{O comportamento das demais variáveis}

Analisando as demais variáveis, pode-se destacar a influência da variável CUSTO DO FinANCIAMENTO HABITACIONAL, que apresentou o segundo maior coeficiente de correlação de Pearson $(-0,66)$. Este resultado demonstra o impacto já esperado da 
redução do comprometimento da parcela de financiamento na renda dos compradores na atividade da Produção Habitacional PRIVAdA, e que também está relacionada com a oferta de recursos.

Outro resultado aderente ao preconizado na revisão bibliográfica foi a evolução da Produção Habitacional Privada segundo o comportamento da RENDA que apresentou o terceiro maior valor de $\mathrm{r}(+0,50)$, confirmando sua correlação positiva.

O comportamento do PREÇO, no entanto, apresentou no período de 1998 a 2008 uma tendência de queda, o que pode indicar que o nível de desenvolvimento do mercado habitacional da cidade de São Paulo ainda não atingiu o patamar que implica em pressão dos preços dos imóveis em função da dinâmica do mercado. $\mathrm{O}$ coeficiente de correlação de Pearson $(0,06)$ confirmou esta fraca correlação, diferentemente do preconizado na revisão bibliográfica contrapondo, portanto, qualquer hipótese de incremento nos preços devido ao recente aumento da PRODUÇÃo HABITACIONAL PRIVADA na cidade de São Paulo.

A Taxa de Atratividade, por sua vez, apresentou uma correlação negativa conforme o preconizado, no entanto, de forma moderada com um $r=-0,32$. Este resultado pode ser atribuído as fortes distorções da taxa Selic no início do período, o que dificultou a leitura dos agentes do mercado, e conseqüentemente, sua atividade.

Além das variáveis condicionantes mencionadas, os indicadores Índice de Confiança da indústria $(\mathrm{r}=+0,58)$ e PIB $(\mathrm{r}=+0,67)$ também apresentaram uma correlação expressiva com a produção habitacional apesar de não serem mencionadas na revisão bibliográfica. 
7.4. Potencial não atendido pelo mercado de produção privada no período

Conforme exposto no item 2.4, apenas uma parcela da produção de unidades é realizada na modalidade de ProdUÇÃo HABITACIONAL PRIVADA. Relacionando a formação de domicílios e a produção de unidades habitacionais no período selecionado, pode-se estimar a parcela que foi atendida pelas demais modalidades como a produção própria.

Seguindo este raciocínio, esta parcela correspondeu no período a um mercado de 372 mil unidades habitacionais, ou uma média anual de 34 mil unidades, o que representa 1,3 vezes a produção habitacional no período.

Conforme mencionado no item 4.2.3 não é possível afirmar como essa demanda foi acomodada. No entanto, pode-se destacar que a produção habitacional privada não foi capaz de absorver todo o potencial da formação de domicílios. Conforme as conclusões deste trabalho, esse potencial somente poderia ter sido atendido no período com uma condição de oferta de recursos diferente.

Conforme detalhado, além de mais recursos disponíveis no $\mathrm{SFH}$, devido sua ineficiência para suportar a equação de fundo dos empreendedores, seria necessário recursos disponíveis no mercado de capitais para que o patamar de produção fosse elevado a um novo patamar.

\subsection{Sugestão de novas pesquisas}

Dentre aos temas abordados durante o trabalho, pode-se destacar o estudo de alguns itens como sugestão de novas pesquisas conforme detalhado a seguir:

(i) Estoque de imóveis vagos,

Conforme mencionado ao longo do texto, a curva da formação de domicílios não apresenta dados sobre os imóveis que estavam vagos no período. Dessa forma, 
mesmo não havendo indícios, caso a demanda tenha sido absorvida pelos imóveis vagos a formação de domicílios não exigiria obrigatoriamente a produção de unidades.

Como sugestão de novas pesquisas para aprofundar o tema, recomendo a exploração do comportamento do nível de vacância dos imóveis residenciais, avaliando assim sua influência na demanda pela PRODUÇÃo HABITACIONAL

(ii) Estrutura de capital das empresas que realizaram OPA

No item 4.4 é apresentado o número de operações realizadas no mercado de capitais, evidenciando o acesso a novos recursos pelas empresas de diversos setores.

A partir dos dados apresentados, pode-se inferir que a mudança de patamar da produção de unidades no período só foi possível com a participação das empresas que realizaram OPA. Dessa forma, apresento como sugestão o estudo das alternativas disponíveis para estas empresas alavancarem seu crescimento, analisando as deficiências dos recursos do SFH. 


\section{REFERÊNCIAS}

ALENCAR, C. T. A. O Comportamento Macroeconômico Brasileiro e os Impactos no Mercado Residencial na Cidade de São Paulo. In: I SEMINÁRIO INTERNACIONAL DA LARES, 1999. Anais.... São Paulo: LARES, 1999.

AZEVEDO, S. Déficit habitacional no Brasil. Belo Horizonte: Fundação João Pinheiro, 1995.

BARROS, J. R. M. et al. Uma avaliação do mercado imobiliário no Brasil: a evolução da demanda e da oferta de financiamento imobiliário nos próximos cinco anos. São Paulo: ABECIP, 2009.

BERKOWITZ M. K.; HAINES, G. H. JR. Forecasting Future Canadian Residential Heating Demand: An Illustration of Forecasting with Agreggated and Disaggregated Data. Journal of Forecasting, [S.1.], v. 3, n. 2, p. 217-227, april/june 1984 .

BRASIL. Ministério das Cidades, Secretaria Nacional da Habitação, Brasília. CEDEPLAR. Centro de Desenvolvimento e Planejamento Regional, Universidade Federal de Minas Gerais, Belo Horizonte. Projeto Projeção da demanda demográfica habitacional, o déficit habitacional e assentamentos subnormais. Belo Horizonte, 2007.

CAMARANO, A. A.; MEllo, J. L.; KAnSO, S. Do Nascimento À Morte. In: CAMARANO, A. A. (Org.) Transição para a vida adulta ou vida adulta em transição?. Rio de Janeiro: IPEA, 2006. cap.2, p.31-60.

CARN, N. et al. Real estate market analysis: techniques and application. New Jersey: Prentice-Hall, 1988.

COLWELL, P. F. Tweaking the DiPasquale- Wheaton Model. Journal of Housing Economics, [S.1.], n. 11, p. 24-39. 2002.

DIPASQUALE, D. E; WHEATON, W. Housing market dynamics and the future of housing prices. Journal of Urban Economics, [S.1.], n. 35: p. 1-27, 1994.

. The markets for real estate assets and space: a conceptual framework. Journal Of The American Real Estate And Urban Economics Association, [S.1.], n. 20, p.181-97., 1992. Hall, 1996.

Urban Economics and Real Estate Markets. New Jersey: Prentice

ABIKO, A. K. (Coord.). Estudo Prospectivo da Cadeia Produtiva da Construção Civil: Produção e Comercialização de Unidades Habitacionais. 
Secretaria de Tecnologia Industrial, Ministério do Desenvolvimento, Indústria e Comércio Exterior, EPUSP, 2002.

FUNDAÇÃO JOÃO PINHEIRO. Déficit habitacional no Brasil: Municípios selecionados e microrregiões geográficas. 2. ed. Belo Horizonte: Ministério das Cidades, 2005.

Déficit habitacional no Brasil 2005. Belo Horizonte: Ministério das Cidades, 2006.

FRIAS, L. A. M. Projeções da população residente e do número de domicílios particulares ocupados por situação urbana e rural, segundo as Unidades da Federação no período 1985-2020. In: WONG, L. R.; HAKKERT, R.; LIMA, R. A. Futuro da população brasileira: projeções, previsões e técnicas, São Paulo, ABEP, nov. 1987.

FERREIRA, F. P. M. Demanda habitacional: uma metodologia de acompanhamento e previsão para as regiões administrativas do Distrito Federal. Caxambu: ABEP, 2004.

GEBEYEHU, A.; BRAZZODURO, M.; GEBREMEDHIN, B. Housing conditions and demand for housing in urban Ethiopia. Addis Ababa, Roma: CSA, October 2001. (In-Depth Studies From The 1994 Population And Housing)

GENEVOIS, M. L. B. P.; COSTA, O. V. Carência habitacional e déficit de moradias: questões metodológicas. São Paulo em Perspectiva, v. 1, n. 15, 2001.

GRENADIER, S. R. The Persistence of Real Estate Cycles. Journal of Real Estate Finance and Economics, [S.1.], v. 10, p. 95-119, 1995.

GIBLER, K.; NELSON, S.. Consumer Behavior Applications to Real Estate Education. Journal of Real Estate Practice and Education, [S.1.], v. 6, n. 1, 2003.

GIVISIEZ, G. H. N.; RIOS-NETO, E.; SAWYER, D. Projeção da demanda demográfica por domicílios: Aplicação da Metodologia das Taxas de Chefia Baseado em Modelos de Idade-Período-Coorte. In: RIBEIRO, J. Demografia dos Negócios. Campinas: ABEP, 2006.

GOZALO, J. Five Alternative Methods of Estimating Long-Run Equilibrium Relationships. Journal of Econometrics, [S.1.], v. 60, p. 203-233, 1994.

GUJARATI, D. N. Econometria Básica. São Paulo: Makron Books, 2000.

HAMILTON , R. The Influence of Demographic Trends on Housing Demand in the United States: A Descriptive Analysis. Gainesville: University of Florida, 2004. 
IBGE. Projeção da População do Brasil por Sexo e Idade para o Período 1980-2050: Revisão 2004, Metodologia e Resultados... Rio de Janeiro, 2004.

KEARL, J. Inflation, Mortgages, and Housing. Journal of Political Economy, [S.1.], v. 87, n.5, p.1115-38, 1979.

KOHLER, M. A. Financiamento Habitacional. Brasília: Consultoria Legislativa do Senado Federal, 2005.

PEREIRA-LEITE, L. R. Estudo das estratégias das empresas incorporadoras do Município de São Paulo no segmento residencial no período de 1960-1980. São Paulo: FAU-USP, 2006.

LIU, E.; WU, J.; LEE, V.; LEE. J. Study of Housing Demand Model. Hong Kong: Research and Library Services Division Legislative Council Secretariat, 1996.

MACLENNAN, D. Housing Economics. New York: Longman Press, 1979.

MANKIW, N. E; WEIL, D. The Baby Boom, the Baby Bust, and the Housing Market. Regional Science and Urban Economics, [S.1.], v. 19, p. 235-58, 1989.

MEGBolugBe, I. F. et al. The economic theory of housing demand. Washington: American University, 1991.

MEYER, J. Demanda Residencial e Ondas Demográficas no Brasil. In: VI SEMINÁRIO INTERNACIONAL DA LARES, 2006. Anais.... São Paulo: LARES, 2006.

MEYER, J. Demanda residencial: Adequação da Análise de Mercado Imobiliário - O Caso de São Paulo. São Paulo: FAU-USP, 2008.

MONETTI, E. Demanda por Recursos para Financiar a Comercialização do Produto Habitacional na Cidade de São Paulo. São Paulo: EPUSP, 1999.

SERRA, M. V.; O’DELL, W. J.; MACEDO, J.; SMITH M. T.; MORAIS, M. P.; VARELLA, S. F.; NGUYEN, D. Affordable Housing Needs Assessment Methodology: The Adaptation Of The Florida Model To Brazil. Brasília: IPEA, 2005.

MUTH, R. The Demand for Non-Farm Housing. In: HARBERGUER, A. C. (Ed.). The Demand for Durable Goods. Chicago: University of Chicago Press, 1960. p.29-96.

- Models of Land-Use, Housing, and Rent: an Evaluation. Journal of Regional Science, [S.1.], v. 25, n. 4, p. 593-606, 1985.

. Housing Market Dynamics. Regional Science and Urban Economics, North-Holland, v. 18, p. 345-56, 1988. 
NELSON, C. R. Applied time series analysis for managerial forecasting. San Francisco: Holden-Day, 1973.

NOLL, P. F.; O'DELL, W.; SMITH, M. T., SULLIVAN, J. Florida's Affordable Housing Needs Assessment Methodology. Journal of the American Planning Association, [S.l.], v. 63, n. 4, p.495-508.

OLSEN, E. A. Competitive Theory of the Housing Market. American Economic Review, [S.1.], v. 59, n. 4, p. 612-622, 1969.

O’SULLIVAN, A. Urban Economics. 2ed. [S.1.]: Irwin Editors, 1993.

PINHO, M. A.; FREIRE, D. G. Ocupação, Renda e Acumulação de Capital Fixo Produtivo: As Condições Estruturais de Apropriação dos Dividendos Demográficos no Brasil. In: Seminário População, Pobreza e Desigualdade, 2007. Anais... Belo Horizonte: ABEP, 2007

PNAD. Pesquisa Nacional por Amostra de Domicílios: síntese de indicadores. Rio de Janeiro: IBGE, 1997.

REVISTA FGV: conjuntura da construção. São Paulo: Ano 4, n. 2, julho 2006.

RIOS NETO, E. L. G.; OLIVEIRA, A. M. H. C. Aplicação de um modelo de idade-período-coorte para a atividade econômica no Brasil Metropolitano. Pesquisa e Planejamento Econômico, [S.1.], v. 29, n. 2, p. 243-271, 1999.

ROCHA LIMA JR, J. Planejamento do Produto no Mercado Habitacional. Boletim Técnico da EPUSP/PCC. São Paulo, n. 110, 1993.

. Análise de Investimentos: Princípios e técnicas para empreendimentos do setor da construção civil. Texto Técnico da EPUSP/PCC. São Paulo, n.6, 1993.

RUNNELS, J.A. Projecting Housing Demand From Demographics. Real Estate Issues, v.14, n.1, p. 14-20, spring/summer 1989.

SANTOS, C. H.; CRUZ, B. A dinâmica dos Mercados Habitacionais Metropolitanos: Aspectos teóricos e uma Aplicação para a Grande São Paulo. Brasília: IPEA, 2000.

SANTOS, C. H. Políticas Federais de Habitação no Brasil: 1964/1998. Brasília: IPEA, 1999.

SIRMANS, G. S. E; BENJAMIN, J. D. Determinants of Market Rent. The Journal of Real Estate Research, [S.1.], v. 6, n. 3, 1991.

UNITED NATIONS. Housing requirements and demand: current methods of assessment and problems of estimation. Geneva: United Nations Publication, 1973. 
VASCONCELOS, J. R.; CÂNDIDO JÚNIOR, J. O. O Problema Habitacional no Brasil: Déficit, Financiamento e Perspectivas. Brasília: IPEA, 1996.

VEDROSSI, A. O. A securitização de recebíveis imobiliários: uma alternativa de aporte de capitais para empreendimentos residenciais no Brasil. São Paulo: EPUSP, 2002.

WHEATON, W. Real Estate "Cycles". Real Estate Economics, v. 27, n.2, p. 209-230, 1999.

WHEATON, W.; LEE, N. Do Housing Sales Drive Prices or the Converse? Massachusetts Institute of Technology Department of Economics Working Paper. Cambridge, MA, n. 08-01, 2007.

WILLIAMS, J. Equilibrium and Options on Real assets. Review of Financial Studies, [S.1.], v. 6, p. 825-850, winter 1993.

WHITEHEAD, C. A Model of the UK Housing Market. Bulletin of the Oxford University Institute of Economics and Statistics, Oxford, v .33, p. 245-266, 1971.

. The UK Housing Market: an Econometric Model. Farnborough: Hants., Saxon House, 1974. 